\title{
Characterization of Transport and Solidification in the metal Recycling Processes
}

\author{
Final Report \\ August 6, 1997
}

\author{
By: \\ M. A. Ebadian; Z. F. Dong \\ R. C. Xin
}

Work Performed Under Contract No.: DE-FG21-95EW55094

For

U.S. Department of Energy

Office of Fossil Energy

Federal Energy Technology Center

P.O. Box 880

Morgantown, West Virginia 26507-0880

By

Florida International University

Hemispheric Center for Environmental Technology (HCET)

Center for Engineering \& Applied Sciences

10555 West Flagler Street

EAS-2100

Miami, Florida 33174 


\section{Disclaimer}

This report was prepared as an account of work sponsored by an agency of the United States Government. Neither the United States Government nor any agency thereof, nor any of their employees, makes any warranty, express or implied, or assumes any legal liability or responsibility for the accuracy, completeness, or usefulness of any information, apparatus, product, or process disclosed, or represents that its use would not infringe privately owed rights. Reference herein to any specific commercial product, process, or service by trade name, trademark, manufacturer, or otherwise does not necessarily constitute or imply its endorsement, recommendation, or favoring by the United States Government or any agency thereof. The views and opinions of authors expressed herein do not necessarily state or reflect those of the United States Government or any agency thereof. 


\section{DISCLAIMER}

Portions of this document may be illegible electronic image products. Images are produced from the best available original document. 


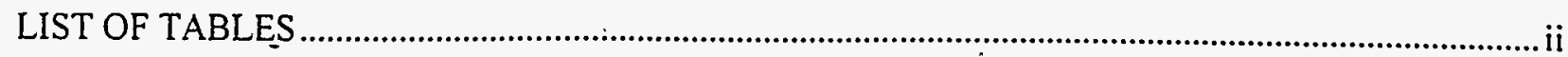

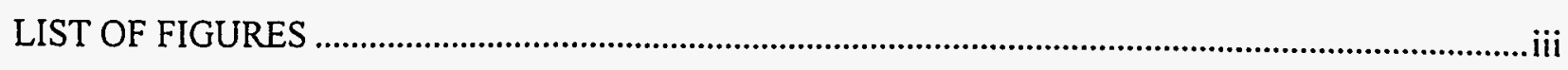

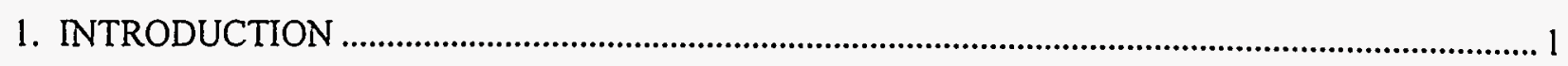

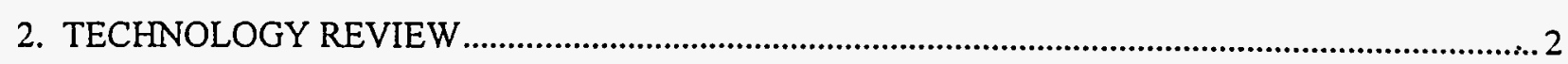

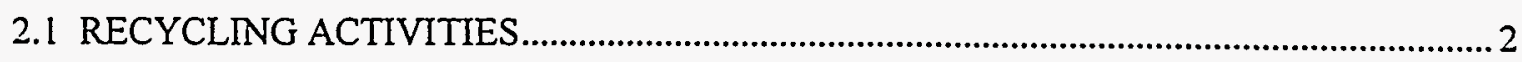

2.2 IDENTIFICATION AND EVALUATION OF CHARACTERIZATION

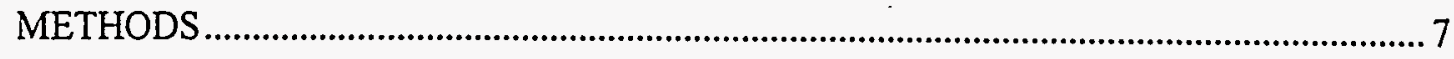

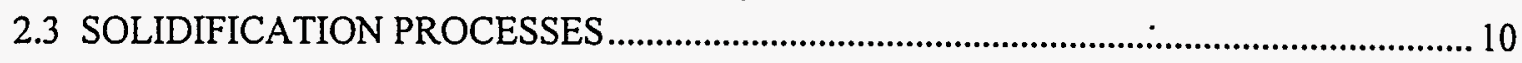

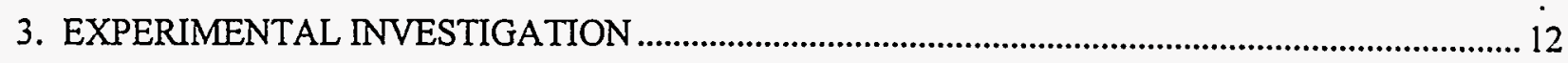

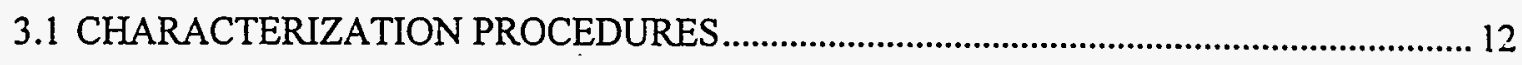

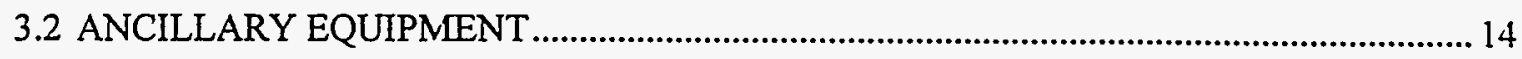

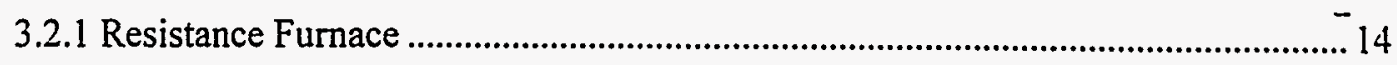

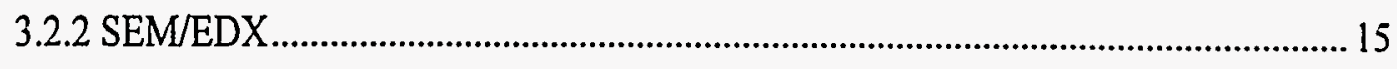

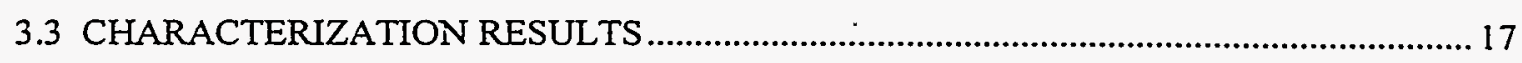

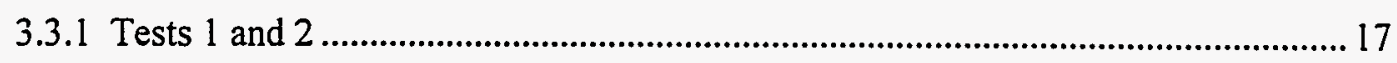

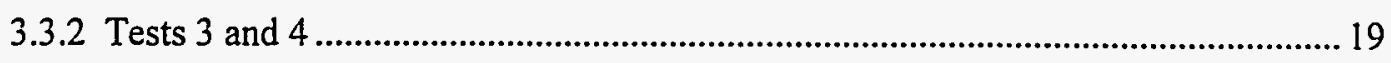

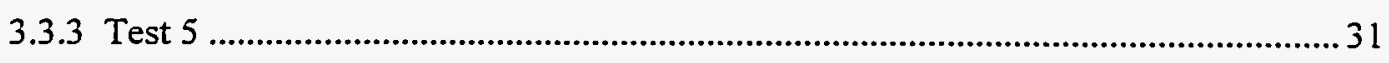

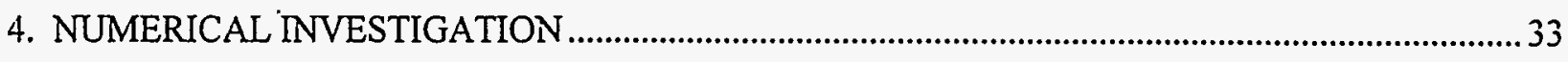

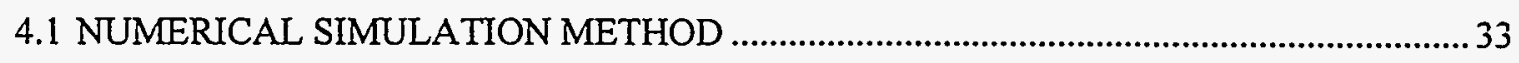

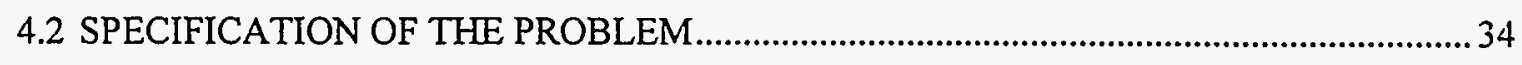

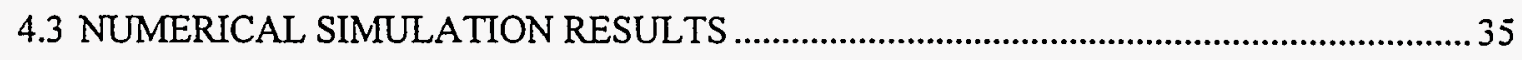

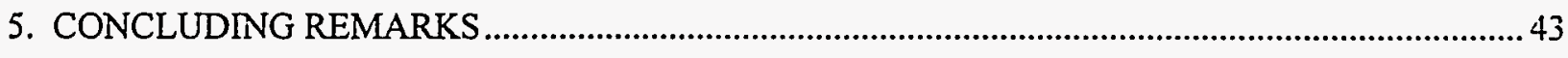

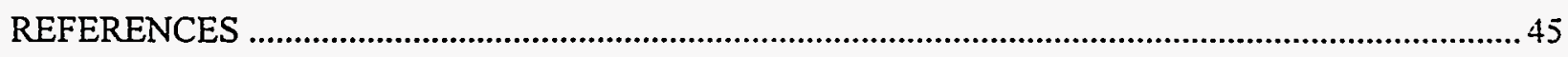




\section{LIST OF TABLES}

Table 1. Summary of Research and Recycling Activities ....................................................2

Table 2. Contaminant Characterization Methods .......................................................................8

Table 3. The Solid/Liquid Interface Detection Methods ......................................................10

Table 4. Melt Ingredients, Melting Conditions, and Weight Changes ....................................17

Table 5. Distribution of Cesium and Chlorine in the Ingots Produced in Tests 1 and 2 ............18

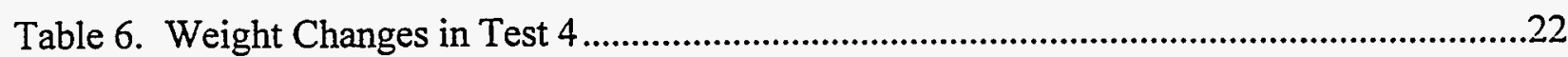

Table 7. Composition of the Bottom Surface of the Ingot Produced in Test 4..........................23

Table 8. Composition of the Elements Detected by EDX on the Ingot Surface of Test 5............31

Table 9. Thermal Properties of Aluminium and Iron in Solid and Molten Phase .......................34

Table 10. Maximum Velocities in Molten Metal Pool (m/s) ...................................................35 


\section{LIST OF FIGURES}

Figure 1. Schematic drawing of the characterization process.....................................................13

Figure 2. Flow chart of the characterization process ...............................................................13

Figure 3. Photograph of the furnace....................................................................................15

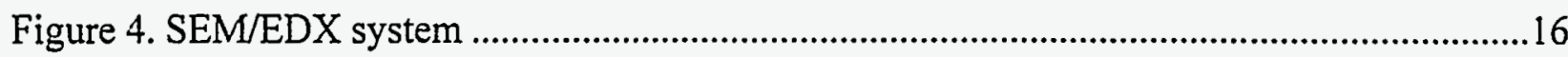

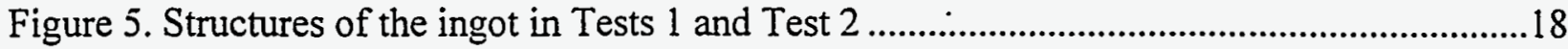

Figure 6. Structures of the gray powder residual in the crucible ................................................19

Figure 7. Microphotographs of the bottom and side surfaces of the ingot produced in

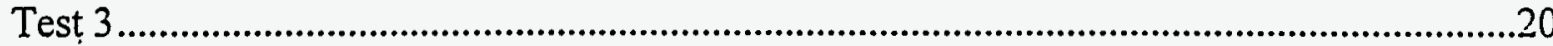

Figure 8. Local composition and EDX spectrograms of the bottom surface of the ingot

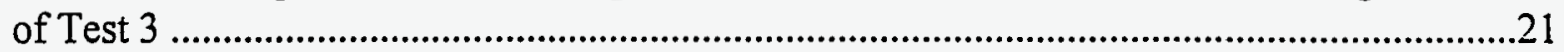

Figure 9. Local composition and EDX spectrograms of the top surface of the ingot of Test 4.

Figure 10. Microphotographs of the top surface of the ingot produced in Test 3 (dendrities of proeutetic aluminum surrounded by eutetic mixture of aluminum and silicon) .22

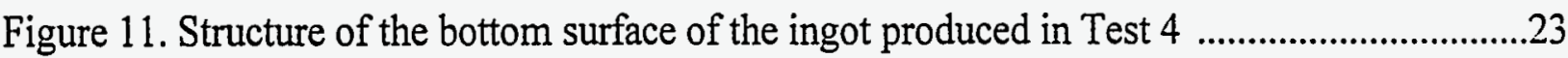

Figure 12. Local composition and EDX spectrograms the bottom surface of the ingot produced during Test 4 .........................................................................................................25

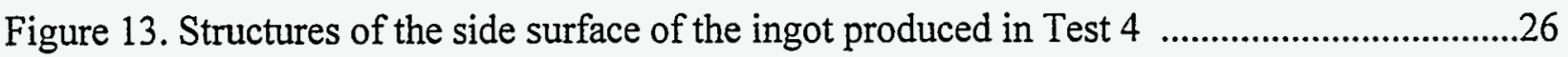

Figure 14. Structures of the top surface of the ingot produced in Test 4 .......................................26

Figure 15. Local composition and EDX spectrograms of the top surface of the ingot produced in Test 4

Figure 16. Structures of the cross section of the ingot produced in Test 4 .28

Figure 17. Local composition and EDX spectrograms of the cross section of the ingot produced in Test 4 .

Figure 18. Microphotographs of the surface of the ingot produced in Test 5 .

Figure 19. Temperature distribution, solidification patterns, and flow field for molten aluminum solidification (case $1, t=10 \mathrm{~s}$ )

Figure 20. Temperature distribution, solidification patterns, and flow field of molten aluminum solidification (case $1, t=20 \mathrm{~s}$ ).

Figure 21. Temperature distribution, solidification patterns, and flow field for molten aluminum solidification (case $2, \mathrm{t}=40 \mathrm{~s}$ ) 
Figure 22. Temperature distribution; solidification patterns, and flow field for molten aluminum solidification (case $2 . t=80 \mathrm{~s}$ ).

Figure 23. Temperature distribution, solidification patterns, and flow field for molten aluminum solidification (case $2, \mathrm{t}=160 \mathrm{~s}$ )... .38

Figure 24. Temperature distribution, solidification patterns, and flow field for molten aluminum solidification (case $3, \mathrm{t}=40 \mathrm{~s}$ ).

Figure 25. Temperature distribution, solidification patterns, and flow field for molten aluminum solidification (case $3, t=80 \mathrm{~s}$ ).

Figure 26. Temperature distribution, solidification patterns, and flow field for molten aluminum solidification (case $3, \mathrm{t}=160 \mathrm{~s}$ ).

Figure 27. Temperature distribution, solidification patterns, and flow field for molten iron solidification (case $1, \mathrm{t}=40 \mathrm{~s}$ )

Figure 28. Temperature distribution, solidification patterns, and flow field for molten iron solidification (case $\mathrm{l}, \mathrm{t}=80 \mathrm{~s}$ ).

Figure 29. Temperature distribution, solidification patterns, and flow field for molten iron solidification (case $1, \mathrm{t}=160 \mathrm{~s}$ ). 


\section{INTRODUCTION}

The characterization of the transport and solidification of metal in the melting and casting processes is significant for the optimization of the radioactively contaminated metal recycling and refining processes. In this research project, the transport process in the melting and solidification of metal was numerically predicted, and the microstructure and radionuclide distribution have been characterized by scanning electron microscope/electron diffractive $\mathrm{X}$-ray (SEM/EDX) analysis using cesium chloride ( $\mathrm{CsCl}$ ) as the radionuclide surrogate. In the melting and solidification process, a resistance furnace whose heating and cooling rates are programcontrolled in the helium atmosphere was used. The characterization procedures included weighing, melting and solidification, weighing after solidification, sample preparation, and SEM/EDX analysis.

This analytical methodology can be used to characterize metal recycling and refining products in order to evaluate the performance of the recycling process. The data obtained provide much valuable information that is necessary for the enhancement of radioactive contaminated metal decontamination and recycling technologies. The numerical method for the prediction of the melting and solidification process can be implemented in the control and monitoring system ${ }^{-}$of the melting and casting process in radioactive contaminated metal recycling. The use of radionuclide surrogates instead of real radionuclides enables the research to be performed without causing harmful effects on people or the community.

This characterization process has been conducted at the Hemispheric Center for Environmental Technology (HCET) at Florida International University since October 1995. Tests have been conducted on aluminum ( $\mathrm{Al}$ ) and copper $(\mathrm{Cu})$ using cesium chloride $(\mathrm{CsCl})$ as a radionuclide surrogate, and information regarding the radionuclide transfer and distribution in melting and solidification process has been obtained. The numerical simulation of the solidification of molten metal has been very successful for aluminium; however, a stability problem in the simulation of iron/steel solidification poses a challenge. Thus, additional development is needed to simulate the radionuclide transfer and distribution behaviors in the melting and casting processes.

This project was initially based on a two-year plan. However, due to technical and financial difficulties, the project ended in FY96. The work which has been accomplished in the first year includes the characterization of radionuclide transfer and distribution in the melting-solidification process and the numerical simulation of metal solidification.

The Argon-arc melting method was tested for the melting of copper and steel materials. Five tests were performed to characterize the transfer and distribution of radionuclides in the aluminium and copper melting/solidification process using $\mathrm{CsCl}$ as radionuclide surrogates. The numerical simulation of molten aluminium and steel solidification process was performed. Different boundary conditions were applied in the simulations. 


\section{TECHNOLOGY REVIEW}

As the first phase of this project, we have done an extensive survey of existing technologies and research activities on the recycling, characterization, and solidification of metal and glass. The information is summarized in the following subsections.

\subsection{RECYCLING ACTIVITIES}

The metal recycling integrated demonstration (ID) is directed at the long-term development of regional commercial RSM recycling industries to service the needs of the DOE. Because of its wide applicability, work on this ID has been initiated for the processing of slug buckets, heat exchangers, and other items at the Savannah River Site (SRS). In FY94, laboratory-scale efforts at Oak Ridge National Laboratory (ORNL) were directed at advanced process development for the decontamination of nickel scrap. Continuing efforts in FY95 and beyond have included processing stainless-steel scrap items from INEL, melting mild steel and nickel scrap from ORNL, and processing other forms of stainless-steel scrap from other DOE-sites.

In pursuit of possible applications of recycled scrap metals for controlled reuse at DOE or other federal sites, various groups within the DOE-EM organization are sponsoring efforts at numerous DOE and commercial sites. DOE is currently releasing some metals on a case-by-case basis, following release criteria. The actual melting of the RSM and the fabrication of the final products is accomplished through subcontracts with private industry.

Studies of metal recycling are being conducted at the following DOE sites: Argonne, Hanford, Idaho, Los Alamos, Oak Ridge, Sandia and Savannah River. DOE-funded efforts are underway or planned at the Environmental Protection Agency (EPA); Sanford Cohen Associates; Scientific Ecology Group, Inc.; Manufacturing Sciences Corporation; Molten Metals Technology, Inc.; Science Application International Corporation (SAIC); Battelle; Columbus; Quadrex Corporation; and Grumman Aircraft. Existing research and recycling activities are summarized in Table 1.

Table 1.

Summary of Research and Recycling Activities

\begin{tabular}{|l|l|l|l|}
\hline \multicolumn{1}{|c|}{ Company } & \multicolumn{1}{|c|}{ Project } & \multicolumn{1}{c|}{ Description } & \multicolumn{1}{c|}{ Reference } \\
\hline $\begin{array}{l}\text { Westinghouse } \\
\text { Savannah River } \\
\text { Company (WSRC) }\end{array}$ & $\begin{array}{l}\text { Stainless Steel } \\
\text { Beneficial Reuse } \\
\text { Demonstration }\end{array}$ & $\begin{array}{l}\text { "Decontaminated 304 SS RSM (-3 pC/g) melted } \\
\text { and refabricated into storage containers." }\end{array}$ & $\begin{array}{l}\text { Boettingger } \\
1994\end{array}$ \\
\hline $\begin{array}{l}\text { MSE, Inc.; } \\
\text { Manufacturing } \\
\text { Sciences } \\
\begin{array}{l}\text { Corporation } \\
\text { (MSC) }\end{array}\end{array}$ & $\begin{array}{l}\text { Demonstration of } \\
\text { Contaminated Metal } \\
\text { Recycle Integration } \\
\text { and Optimization }\end{array}$ & $\begin{array}{l}\text { "Feasibility and economic study of a plan to } \\
\text { integrate commercial steel mill technology with } \\
\text { RSM scrap processing to produce carbon and } \\
\text { stainless-steel sheet and plate at a grade suitable } \\
\text { for fabricating into radioactive waste container } \\
\text { for DOE use. The feasibility analysis and a } \\
\text { conceptual design have been completed." }\end{array}$ & $\begin{array}{l}\text { MSE and } \\
\text { MSC, 1995 }\end{array}$ \\
\hline
\end{tabular}




\section{Table 1.}

\section{Summary of Research and Recycling Activities (Continued)}

\begin{tabular}{|c|c|c|c|}
\hline Company - & Project & Description & Reference \\
\hline $\begin{array}{l}\text { U.S. Steel Group, } \\
\text { a division of USX } \\
\text { Corporation }\end{array}$ & $\begin{array}{l}\text { Laboratory-Scale } \\
\text { Refining Studies on Low } \\
\text { Carbon Aluminium } \\
\text { Killed Steels Using } \\
\text { Synthetic Fluxes. }\end{array}$ & $\begin{array}{l}\text { "Laboratory size }(4.5-5 \mathrm{~kg}) \text {, low-carbon } \\
\text { steel melts were deoxidized using } \mathrm{Al} \text {. } \\
\text { Some of these heats were treated with } \\
\text { different types of synthetic fluxes to } \\
\text { evaluate the oxide inclusion removal } \\
\text { and desulfurization characteristics of } \\
\text { the respective synthetic fluxes. F-I, } \\
12 \mathrm{CaO} .7 \mathrm{Al}_{2} \mathrm{O}_{3} ; \mathrm{F}-\mathrm{II}, 12 \mathrm{CaO} .7 \mathrm{Al}_{2} \mathrm{O}_{3} \\
\& \mathrm{CaO} ; \mathrm{F}-\mathrm{III}, 12 \mathrm{CaO} .7 \mathrm{Al}_{2} \mathrm{O}_{3} \\
\& \mathrm{CaO} \& \mathrm{CaF}_{2} ; \mathrm{F}-\mathrm{IV}, \\
12 \mathrm{CaO} .7 \mathrm{Al}_{2} \mathrm{O}_{3} \& \mathrm{CaO} \& \mathrm{BaO} \& \mathrm{CaF}_{2} ; \mathrm{F}- \\
\mathrm{V}, 12 \mathrm{CaO} .7 \mathrm{Al}_{2} \mathrm{O}_{3} \& \mathrm{BaO} \& \mathrm{CaF}_{2} . "\end{array}$ & $\begin{array}{l}\text { Patsiogiannis et al. } \\
1994\end{array}$ \\
\hline $\begin{array}{l}\text { Martin Marietta } \\
\text { Energy Systems } \\
\text { (MMES) }\end{array}$ & $\begin{array}{l}\text { Metal Recycling } \\
\text { Technology Development }\end{array}$ & $\begin{array}{l}\text { Surveying DOE facilities available for } \\
\text { recycling scrap stainless steel. }\end{array}$ & Glenn Bastians 1996 \\
\hline $\begin{array}{l}\text { Manufacturing } \\
\text { Science } \\
\text { Corporation } \\
\text { (MSC) }\end{array}$ & $\begin{array}{l}\text { Advanced Technologies } \\
\text { for Decontamination and } \\
\text { Conversion of Scrap } \\
\text { Metal }\end{array}$ & $\begin{array}{l}\text { "Inducto-slag refining process. The } \\
\text { contaminant is incorporated into the } \\
\text { slag. Experiments were performed both } \\
\text { with technetium and a surrogate, } \\
\text { rhenium, as the contaminant in nickel. } \\
\text { The predicted level of decontamination } \\
\text { was not achieved in any of the } \\
\text { experiments." }\end{array}$ & Muth et al. 1994 \\
\hline $\begin{array}{l}\text { Martin Marietta } \\
\text { Energy Systems } \\
\text { (MMES) }\end{array}$ & $\begin{array}{l}\text { Contaminated Nickel } \\
\text { Scrap Processing }\end{array}$ & $\begin{array}{l}\text { Several industrial-scale processes used } \\
\text { for the purification of nickel were } \\
\text { reviewed, including electrorefining, } \\
\text { electrowinning, vapometallurgy, and } \\
\text { ammonia leaching. }\end{array}$ & Compere et al. 1994 \\
\hline $\begin{array}{l}\text { Oak Ridge } \\
\text { National } \\
\text { Laboratory } \\
\text { (ORNL) }\end{array}$ & $\begin{array}{l}\text { High-Temperature } \\
\text { Chemical Separation of } \\
\text { Waste Materials }\end{array}$ & $\begin{array}{l}\text { "Ratio frequency and crucible } \\
\text { technologies have recently been applied } \\
\text { to separation, purification, and } \\
\text { recycling of uranium alloys and } \\
\text { structural materials. These slagging } \\
\text { separations technologies enable the } \\
\text { reuse of many materials." }\end{array}$ & ORNL 1994 \\
\hline $\begin{array}{l}\text { Scientific Ecology } \\
\text { Group (SEG), Oak } \\
\text { Ridge National } \\
\text { Laboratory }\end{array}$ & Melting Down RSM & $\begin{array}{l}\text { "Induction furnace ( } 20 \text { ton) was used to } \\
\text { melt radioactive contaminated ferrous } \\
\text { metals; } 4,940 \text { tons of scrap metal were } \\
\text { melted in } 1993 . "\end{array}$ & $\begin{array}{l}\text { Worcester et al. } \\
1995\end{array}$ \\
\hline $\begin{array}{l}\text { Idaho National } \\
\text { Engineering } \\
\text { Laboratory (INEL) }\end{array}$ & $\begin{array}{l}\text { Sizing and melting } \\
\text { development activities } \\
\text { using contaminated metal } \\
\text { at the waste experimental } \\
\text { reduction facility }\end{array}$ & $\begin{array}{l}\text { "Induction furnace ( } 0.8 \text { ton) was used } \\
\text { to melt radioactively contaminated } \\
\text { ferrous metals; } 80 \text { tons of scrap metal } \\
\text { were melted in } 1985 . "\end{array}$ & Larsen et al. 1985 \\
\hline
\end{tabular}


Table 1.

Summary of Research and Recycling Activities (Continued)

\begin{tabular}{|c|c|c|c|}
\hline Company & Project & Description & Reference \\
\hline $\begin{array}{l}\text { Montana Tech of } \\
\text { the University of } \\
\text { Montana }\end{array}$ & $\begin{array}{l}\text { INEL Metal Recycling } \\
\text { Program }\end{array}$ & $\begin{array}{l}\text { "Work at Montana Tech has focused on } \\
\text { induction and plasma hearth melting of } \\
\text { carbon and stainless steels. Results } \\
\text { show that induction melting can be } \\
\text { performed using a variety of } \\
\text { metallurgical slags which effectively } \\
\text { decontaminate both carbon and } \\
\text { stainless steels. Initial results using the } \\
\text { plasma hearth do not match the } \\
\text { decontamination efficiency of induction } \\
\text { melting." }\end{array}$ & Bechtold 1994 \\
\hline $\begin{array}{l}\text { Oregon Graduate } \\
\text { Institute of } \\
\text { Science and } \\
\text { Technology (OGI) }\end{array}$ & $\begin{array}{l}\text { INEL Metal Recycling } \\
\text { Program }\end{array}$ & $\begin{array}{l}\text { "Work at OGI focused on the vacuum } \\
\text { arc remelt (VAR) and electroslag } \\
\text { remelt techniques (ESR). The VAR } \\
\text { results showed poor decontamination } \\
\text { efficiency. ESR results show promise } \\
\text { for high decontamination efficiency } \\
\text { and ingot cleanness. Cooperate with } \\
\text { Northwest Consortium on the second- } \\
\text { phase activities." }\end{array}$ & Bechtold 1994 \\
\hline $\begin{array}{l}\text { Colorado School } \\
\text { of Mines (CSM) }\end{array}$ & $\begin{array}{l}\text { INEL Metal Recycling } \\
\text { Program }\end{array}$ & $\begin{array}{l}\text { "Electrochemical reactions in the ESR } \\
\text { technique, which could drive a metal } \\
\text { refining/ decontamination reaction } \\
\text { when there is negligible thermo- } \\
\text { chemical driving force, are being } \\
\text { studied at CSM." }\end{array}$ & Bechtold 1994 \\
\hline Retect, Inc. & $\begin{array}{l}\text { INEL Metal Recycling } \\
\text { Program }\end{array}$ & $\begin{array}{l}\text { "Continuation of the work of Montana } \\
\text { Tech on the plasma hearth remelting. } \\
\text { Examining use of refining slags, } \\
\text { oxygen-containing torch gases, and } \\
\text { cold-hearth refractories for the removal } \\
\text { of rare earth surrogates from stainless } \\
\text { steel feedstock." }\end{array}$ & Bechtold 1994 \\
\hline $\begin{array}{l}\text { Newport News } \\
\text { Shipbuilding }\end{array}$ & $\begin{array}{l}\text { INEL Metal Recycling } \\
\text { Program }\end{array}$ & $\begin{array}{l}\text { "Production-scale validation melts } \\
\text { using an induction furnace. Rare earth } \\
\text { surrogates can be removed by air } \\
\text { induction melting/slag refining to levels } \\
\text { less than one ppm with the feedstock of } \\
\text { about } 270,230 \text {, and } 170 \text { ppm for Ce, } \\
\text { La and Nd, respectively." }\end{array}$ & Bechtold 1994 \\
\hline
\end{tabular}


Table 1.

Summary of Research and Recycling Activities (Continued)

\begin{tabular}{|c|c|c|c|}
\hline Company & Project & Description & Reference \\
\hline $\begin{array}{l}\text { DOE, EM } \\
\text { Westinghouse } \\
\text { Hanford } \\
\text { Company. }\end{array}$ & $\begin{array}{l}\text { Technical Issues Relating } \\
\text { to The Recycle of } \\
\text { Contaminated Scrap } \\
\text { Metals }\end{array}$ & $\begin{array}{l}\text { A review of the literature on melting of } \\
\text { radioactive metals with attention to the } \\
\text { resultant partitioning of radioactivities. } \\
\text { Important technical issues relating to } \\
\text { the recycling of radioactive scrap } \\
\text { metals have beenidentified and } \\
\text { discussed. }\end{array}$ & $\begin{array}{l}\text { Warren and Clark } \\
1994\end{array}$ \\
\hline $\begin{array}{l}\text { Westinghouse } \\
\text { Idaho Nuclear } \\
\text { Company } \\
\text { (WINCO) }\end{array}$ & $\begin{array}{l}\text { System Approach to the } \\
\text { Management of a } \\
\text { Contaminated Metal } \\
\text { Recycling Project. }\end{array}$ & $\begin{array}{l}\text { "WINCO is working with private } \\
\text { industry to recycle contaminated metal } \\
\text { from the dismantling and } \\
\text { decommissioning of DOE sites and } \\
\text { commercial reactors. System analysis } \\
\text { provides a way.to deal with many } \\
\text { complex issues and supports effective } \\
\text { decisionmaking:". }\end{array}$ & $\begin{array}{l}\text { Pincock and } \\
\text { Wahnachaffe } 1994\end{array}$ \\
\hline $\begin{array}{l}\text { Argonne National } \\
\text { Laboratory (ANL) }\end{array}$ & $\begin{array}{l}\text { Evaluation of } \\
\text { Radioactive Scrap Metal } \\
\text { Recycling }\end{array}$ & $\begin{array}{l}\text { The human health risks and } \\
\text { environmental and sociopolitical } \\
\text { impacts of options for recycling } \\
\text { radioactive scrap metal or disposing of } \\
\text { and replacing it were evaluated." }\end{array}$ & Nieves et al. $1995^{-}$ \\
\hline $\begin{array}{l}\text { University } \\
\text { Politechnica } \\
\text { Bucharest, } \\
\text { Rumania }\end{array}$ & $\begin{array}{l}\text { Complex Processing of } \\
\text { Molten Secondary } \\
\text { Aluminum. }\end{array}$ & $\begin{array}{l}\text { "A new in-line technology for complex } \\
\text { treatment of secondary aluminum and } \\
\text { aluminum alloys which combines metal } \\
\text { filtering, alkali removal and degassing } \\
\text { operations into a single unit. Degassing } \\
\text { is made by piping } \mathrm{Ar}+\mathrm{Cl}_{2} \text { through the } \\
\text { molten metal. The filtration chamber } \\
\text { contains two layers bed: } 1) \text { titanium } \\
\text { sponge and } 2 \text { ) flux }\left(52 \% \mathrm{MgCl}_{2}+20 \%\right. \\
\mathrm{KCl}+16 \% \mathrm{MgF}_{2}+12 \% \mathrm{CaF}_{2} \text { ) covered } \\
\text { alumina balls and tabular alumina } \\
\text { granules." }\end{array}$ & Moldovan 1993 \\
\hline
\end{tabular}

Source: Compiled by the author from the above-referenced works.

Existing and underdeveloped technologies include direct cast into the waste container, melt refining/slagging, the electrolysis process, and the catalytic extraction process. The recycling method currently used by the DOE at the Savannah River Site is the direct cast of the stainless steel into waste containers. This method can be applicable to the surface decontaminated RSM where only low-level contamination of the accessible surface has occurred and the decontamination or removal of radioactivity by chemical or mechanical methods is readily achievable. The DOE has the intention to establish an industry program to integrate commercial steel mill technology with RSM scrap processing to produce carbon and stainless-steel sheet and plate at a grade suitable for fabricating radioactive waste containers. The feasibility analysis and 
a conceptual design have been done by MSE, Inc. and Manufacture Science Corporation (MSC) (1995).

However, where volumetric or persistent contamination and inaccessible surfaces are involved, melt refining/slagging processing is recognized as a desirable option. This method has the advantages of volume reduction; production of useful product sizes, shapes, and volumes; homogenization of radioactivities; reduced radiation exposure; and the partitioning of radioactivities, including an effective removal of radionuclides for certain RSM. Since early 1993, Idaho National Engineering Laboratory (INEL) and Westinghouse Idaho Nuclear Company, Inc. have been running a project for the decontamination of metals by melting refining/slagging (Lockheed Idaho Technologies Company-1995; :Worcester et al. 1994; May 1994). Several excellent reviews of projects involving the melting of radioactive metals have been published (Worcester et al. 1995; Mautz et al. 1975; Reimann 1991; Nakamura 1994; Hobbick et al. 1981).

Several melt refining/sluggiñg methods "exist-induction furnace and electric arc furnace, electroslag refining, and:thermal plasma. Induction melting can achieve very rapid heating and high melting rates. Also, the induction currents stir the bath vigorously, which assures more uniform composition and temperature during the melting. An induction furnace reportedly produces only 20 percent as much effluent dust as an electric arc furnace (EAF) of similar capacity (Reimann 1991). The EAF is the most common method of stainless steel production today, but it is not the preferred method for melting RSM because of the tremendous amount of mixed waste, noise, and fume generation and inability to contain the fumes.

Electroslag refining, which is a modified melting technology, has been used to melt uranium and plutonium contaminated RSM. In this method, contaminated metal is generally melted in a molten slag in a mold by Joule heat generated with large amounts of electrical current and then gradually solidified in the same mold. For selected applications, success in partitioning of radioactivity between the metal and slag has been reported for this technology (Ochiai et al. 1993; Uda et al. 1987). The use of thermal plasma as a possible melting technique for the recycling of metals from waste is discussed by Burkhard et al. (1994). This method is suggested and has been tested for recycling metals from mixed type metallic waste.

The melt refining/slagging process is also used to decontaminate and recycle the contaminated nickel associated with the gaseous diffusion plants The possibility of using nickel scrap as an alloy constituent to produce \$304 stainless steel in MSC's vacuum induction melting process has also been studied. Slag decontamination processes have been tested. Experiments have been performed with technetium and a surrogate, rhenium, as the contaminant in nickel. The predicted level of decontamination was not achieved in any of the experiments. (Muth et al. 1994) Refining of low carbon aluminum killed steel using synthetic fluxes has been studied in laboratory-scale experiments. The fluxes used were F-I, $12 \mathrm{CaO}_{7} \mathrm{Al}_{2} \mathrm{O}_{3} ; \mathrm{F}-\mathrm{II}, 12 \mathrm{CaO}_{7} 7 \mathrm{Al}_{2} \mathrm{O}_{3} \& \mathrm{CaO} ; \mathrm{F}-\mathrm{III}$, $12 \mathrm{CaO} .7 \mathrm{Al}_{2} \mathrm{O}_{3} \& \mathrm{CaO} \& \mathrm{CaF}_{2} ; \quad \mathrm{F}-\mathrm{IV}, \quad 2 \mathrm{CaO}_{7} \mathrm{Al}_{2} \mathrm{O}_{3} \& \mathrm{CaO} \quad \& \mathrm{BaO} \quad \& \mathrm{CaF}_{2} ; \quad \mathrm{F}-\mathrm{V}$, 12CaO.7Al2O3\&BaO \& $\mathrm{CaF}_{2}$ (Patsiogiannis et al. 1994).

The electrolysis and catalytic extraction processes have been used for the recovery and recycling of several kinds of metals. Several industrial-scale processes used for the purification of nickel were reviewed by Compere et al. (1994), including electrorefining, electrowinning, 
vapometallurgy, and ammonia leaching. The technologies combine features of industrial electrowinning and electrorefining processes with those of the electrostripping and solvent extraction processes used historically in the nuclear industry. Most the patents related to these kind of technologies cover single unit processes, which are part of a larger metal recovery scheme. Westinghouse has maintained an active interest in this area for more than a decade.

Of these decontamination and recycling methods, melt refining/slugging is the most feasible, low-cost option. Induction melting can achieve very rapid heating and high melting rates. Recycling procedures involving melting usually include the three following steps: 1) pretreatment, which includes decontamination of surface, segregation according to substrate metal, segregation according to radionuclide contaminant, and size reduction/compacting; 2) melting RSM with slug; and 3) solidifying the metal and slag phases.

\subsection{IDENTIFICATION AND EVALUATION OF CHARACTERIZATION METHODS}

DOE's Characterization, Monitoring, and Sensor Technology Crosscutting (CMST-CP) program and its technology needs are described in several recent publications and topical reports (Office of Environmental Management Technology Development 1995; Edelson et al. 1994; Purdy et al. 1994; Wang et al. 1994; and Alders and Purdy 1994). The characterization of radioactively contaminated metals is also important the Facility Deactivation, Decommissioning, and Material Disposition Focus Area (FDDMDFA).

For the melt refining/slagging process, the characterization areas involved include:

1. In-situ identification and measurement of the contamination level of feeding material, slag and metal phases to determine the partition of the contaminants, and elemental analysis of the substrate metal;

2. Characterizing the metallurgical phenomena such as segregation, oxide particulate distribution in the metal ingot; and

3. Detection and monitoring of the solid-liquid interface front in the solidification process.

The characterization methods used for characterization areas (1) and (2), listed above, are summarized in Table 2. As characterization area (3) does not need to be conducted in situ, the SEM/EDX would be the best solution. The Laser Ablation Inductively Coupled Plasma-Mass Spectrometry (LA ICP/MS) is the preferred method for both in-situ and in-lab characterization to identify and measure the contaminants in the metals to meet the first characterization area requirement. 
Table 2.

Contaminant Characterization Methods

\begin{tabular}{|c|c|c|c|c|c|}
\hline Method & Sensitivity & Accuracy & $\begin{array}{l}\text { Time to } \\
\text { Measure }\end{array}$ & Application & Notes \\
\hline $\begin{array}{l}\text { Pulsed Fast } \\
\text { Neutron } \\
\text { Analysis } \\
\text { (PFNA) }\end{array}$ & $\begin{array}{l}\text { To be } \\
\text { determined. } \\
\text { (TBD) }\end{array}$ & $\begin{array}{l}\text { TBD } \\
\because=\end{array}$ & $\begin{array}{l}\text { Real time } \\
\therefore\end{array}$ & $\begin{array}{l}\text { Good for elemental } \\
\text { analysis of metals. }\end{array}$ & $\begin{array}{l}\text { In development, } \\
\text { sampling } \\
\text { needed; } \\
\text { nonintrusive }\end{array}$ \\
\hline $\begin{array}{l}\text { Inductively- } \\
\text { Coupled } \\
\text { Plasma/Mass } \\
\text { Spectrometry } \\
\text { (ICP/MS) }\end{array}$ & $\mathrm{ppb}^{1}$ & 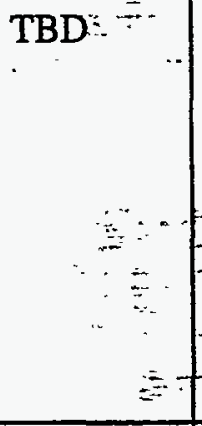 & 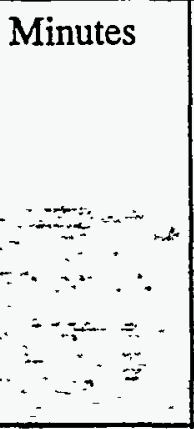 & $\begin{array}{l}\text { Can perform isotopic } \\
\text { analysis of elements. High } \\
\text { cost for instrumentation; } \\
\text { high level of operator } \\
\text { training required. May not } \\
\text { be rugged enough to } \\
\text { survive process conditions. } \\
\text { Simultaneous measurement } \\
\text { of manỳ elements. }\end{array}$ & $\begin{array}{l}\text { Existing; } \\
\text { requires sample } \\
\text { preparation }\end{array}$ \\
\hline $\begin{array}{l}\text { Scanning } \\
\text { Electron } \\
\text { Microscope/ } \\
\text { Energy } \\
\text { Disperse } \\
\text { Type X-ray } \\
\text { Spectrometer } \\
\text { (SEM/EDX) }\end{array}$ & $0.5 \%$ & 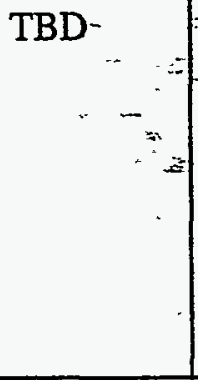 & 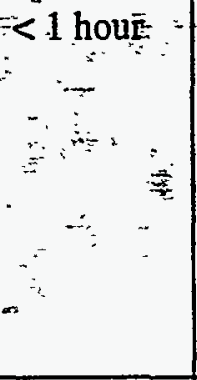 & $\begin{array}{l}\text { Sub-micron surface } \\
\text { resolution; broad elemental } \\
\text { detection; useful for } \\
\text { metals. } \\
\qquad \begin{array}{l}\text {. } \\
\quad\end{array}\end{array}$ & $\begin{array}{l}\text { Existing; } \\
\text { requires sample } \\
\text { preparation }\end{array}$ \\
\hline $\begin{array}{l}\text { Inductively- } \\
\text { Coupled } \\
\text { Plasma } \\
\text { /Atomic } \\
\text { Emission } \\
\text { (ICP/AE) }\end{array}$ & ppb & TBD & Hours & $\begin{array}{l}\text { Will do for most metals. } \\
\text { Minimum detection limit } \\
\text { dependent upon metal. } \\
\text { Multi-element analysis. }\end{array}$ & $\begin{array}{l}\text { Existing; } \\
\text { requires sample } \\
\text { preparation. }\end{array}$ \\
\hline $\begin{array}{l}\text { Electron } \\
\text { Spectroscopy } \\
\text { for chemical } \\
\text { analysis }\end{array}$ & $\mathrm{ppm}^{2}$ & $10 \%$ & Minutes & $\begin{array}{l}\text { Technique dependent upon } \\
\text { specified treatment process }\end{array}$ & $\begin{array}{l}\text { Existing; } \\
\text { requires sample } \\
\text { preparation }\end{array}$ \\
\hline $\begin{array}{l}\text { Atomic } \\
\text { Absorption/A } \\
\text { tomic } \\
\text { Emission } \\
\text { (AA/AE) } \\
\text { Spectroscopy }\end{array}$ & $0.1 \mathrm{ppm}$ & $<10 \%$ & $\begin{array}{l}30-40 \\
\text { minutes }\end{array}$ & $\begin{array}{l}\text { Elemental, rapid, selective; } \\
\text { high sensitivity for alkalis. } \\
\text { Disadvantages - must be in } \\
\text { a lab for safety. Not rapid if } \\
\text { analyte change is required. }\end{array}$ & $\begin{array}{l}\text { Existing; } \\
\text { requires sample } \\
\text { preparation }\end{array}$ \\
\hline
\end{tabular}


Table 2. .

Contaminant Characterization Methods (Continued)

\begin{tabular}{|c|c|c|c|c|c|}
\hline Method & Sensitivity & Accuracy & $\begin{array}{l}\text { Time to } \\
\text { Measure }\end{array}$ & Application & Notes \\
\hline $\begin{array}{l}\text { ICP/MS with } \\
\text { Laser } \\
\text { Ablation (LA } \\
\text { ICP/MS) }\end{array}$ & $\mathrm{ppt}^{3}$ & 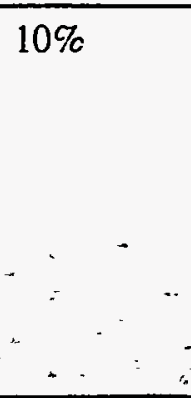 & $\begin{array}{l}\text { Minutes to an } \\
\text { hour }\end{array}$ & $\begin{array}{l}\text { Multi-element capability. } \\
\text { Isotopic analyses can be } \\
\text { performed. Ions (ionized } \\
\text { atoms) quadropole, all } \\
\text { isotopes. Calibrate hourly, } \\
\text { needs to be ruggedized. } \\
\text { Good for-long-lived } \\
\text { isotopes. }\end{array}$ & $\begin{array}{l}\text { In } \\
\text { development; } \\
\text { requires } \\
\text { sample } \\
\text { preparation }\end{array}$ \\
\hline $\begin{array}{l}\text { Tomographic } \\
\text { Gamma } \\
\text { Scanner/ } \\
\text { Segmented } \\
\text { Gamma } \\
\text { Scanner } \\
\text { (TGS/SGS) }\end{array}$ & $\begin{array}{l}1 \mathrm{~g} \\
\mathrm{U}-235 \\
\vdots \\
\vdots \\
\vdots \\
\vdots\end{array}$ & $\begin{array}{l}1-8 \% \\
\text { depending } \\
\text { on sample }\end{array}$ & $\begin{array}{l}30-50 \text { minutes } \\
\vdots \\
\vdots\end{array}$ & $\begin{array}{l}\text { High-energy resolution- } \\
\text { gamma-ray spectroscopic } \\
\text { measurement with an } \\
\text { additional active } \\
\text { correction for matrix } \\
\text { attenuation. TGS allows a } \\
\text { non-uniform distribution } \\
\text { of material in axial } \\
\text { segments: A complete } \\
\text { spatial distribution of } \\
\text { emitting and attenuating } \\
\text { material is determined. }\end{array}$ & \begin{tabular}{l} 
TGS is in \\
development; \\
nonintrusive \\
\hdashline \\
$\therefore$
\end{tabular} \\
\hline
\end{tabular}

1 Parts per billion

2 Parts per million

${ }^{3}$ Parts per trillion

Source: Anderson et al., 1993, pp. 28-31

The detection and monitoring of the solid/liquid interface front can be accomplished by the various methods listed in Table 3. The Pulse-Echo Ultrasonic Technique (PEU) (Krautkramer and Krautkramer 1997) is the preferred method for both in-situ and in-lab measurements. Once this method is successfully implemented, it can also be adapted to the characterization of containerized mixed waste. 
Table 3.

Solid/Liquid Interface Detection Methods

\begin{tabular}{|c|c|c|c|}
\hline Method & $\begin{array}{l}\text { Time to } \\
\text { Measure }\end{array}$ & Application and Specification & Notes \\
\hline $\begin{array}{l}\text { Real Time } \\
\text { Radiography } \\
\text { (RTR) or } \\
\text { Digital } \\
\text { Radiography }\end{array}$ & Real & $\begin{array}{l}\text { Does phase boundary between } \\
\text { liquids and solids. Can distinguish } \\
\text { liquid/solid and homo/heter phases. }\end{array}$ & $\begin{array}{l}\text { Existing; non-intrusive, } \\
\text { Requires development for } \\
\text { specific application }\end{array}$ \\
\hline $\begin{array}{l}\text { Computed } \\
\text { Tomography } \\
\text { (CT), active } \\
\text { and passive }\end{array}$ & Minutes & $\begin{array}{l}\text { Provides quantitative 3-dimensional } \\
\text { stationary views and stationary views } \\
\text { of boundaries between different } \\
\text { densities. Can determine movement } \\
\text { of liquids with view sequencing over } \\
\text { time. Multi-functional. }\end{array}$ & $\begin{array}{l}\text { Existing; non-intrusive; high } \\
\text { cost, not easy to implemented } \\
\text { in real process. } \\
\end{array}$ \\
\hline $\begin{array}{l}\text { Pulse-Echo } \\
\text { Ultrasonic } \\
\text { Technique } \\
\text { (PEU) }\end{array}$ & Real & $\begin{array}{l}\text { This method is good for the solid- } \\
\text { liquid interface detection. It provides } \\
\text { the location of the solid face front at } \\
\text { specific direction and specific time. }\end{array}$ & $\begin{array}{l}\text { Existing; non-intrusive; easy } \\
\text { and economical to establish. }\end{array}$ \\
\hline $\begin{array}{l}\text { Neutron } \\
\text { Radiography }\end{array}$ & $\begin{array}{c}\text { Real; } \\
\text { minutes: } \\
= \\
\quad\end{array}$ & $\begin{array}{l}\text { Similar to RTR. May also be able to } \\
\text { differentiate between } \\
\text { organictaqueous or liquid/liquid } \\
\text { phases: }\end{array}$ & $\begin{array}{l}\text { Further development needed } \\
\text { for this capability }- \\
\text {. }\end{array}$ \\
\hline
\end{tabular}

Source: Anderson et al., 1993, pp. 20-23.

\subsection{SOLIDIFICATION PROCESȘES}

In most alloy solidification processes, three zones exist: the solid and mushy zones and molten liquid. The mushy'zone, comprised of solid dendrites and interdendritic liquid; separates the solidified and melted regions. Transport phenomena such as convection play an important role in the dendrite formation and have an effect on the macrosegregation. Due to methodological difficulties, little experimental research on transport phenomena during alloy solidification has been conducted, though some research have been done on macrosegregation.

Prescott et al. (1994a; 1994b) investigated convective transport phenomena and macrosegregation during $\mathrm{Pb}-\mathrm{Sn}$ alloy solidification numerically and experimentally. In their experiments, temperature and composition measurements, as well as metallographic examinations, were obtained for a $\mathrm{Pn}-\mathrm{Sn}$ alloy in an axisymmetric, annular mold, cooled through its outer wall. Shahani et al. (1994) solidified $\mathrm{Pb}-\mathrm{Sn}$ alloys in a rectangular test cell. They measured transient mold wall temperatures and macrosegregation in solidified ingots. Undercooling-induced macrosegregation in directional solidification was studied by de Groh (1994) for the Pb-Sn system. Ostrogorsky et al. (1994) used a submerged heater to control the 
convection interference with segregation for the $\mathrm{S} n-1$ weight percent (wt \%) Bi alloy. A model alloy (succinonitrile and acetone) was used to study effects of mixed convection on dendrite fragmentation during alloy solidification (Paradies et al. 1994). Experiments were conducted for varying cooling rates, overall temperature differences, melt flow rates, and for two different concentrations of acetone. The results provide a step in the development of solidification models that incorporate fragmentation processes in the mushy zone as an important mechanism of grain refinement and a potential source of macrosegregation in ingots and large castings.

Much more work has been done on the numerical modeling of the solidification of binary alloys (de Groh 1994; Ostrogorsky et al. 1994; Kuznetsov and Vafai 1995; Prescott and Incopera 1995; $\mathrm{Ni}$ and Incopera 1995a and 1995b; Chen et al. 1995; Beckermann and Viskanta 1993; Wang and Beckermann 1994; Sundarrai et al. 1992; Sinha and Sundararajan 1992; and Prescott and Incopera 1992). The basic models used in most numerical modeling work are the continuum model for transport phenomena during metal alloy solidification and its extensions by $\mathrm{Ni}$ and Incopera (1995a; 1995b). The modeling concentrated on several aspects: convective effects on the formation of dendrite and voids, the entrapment of inclusions, macrosegregation, and the development of residual stresses.

The coupling of micro- and macro-scale models is important for the success of the process modeling. Wang and Beckermann (1994) proposed a multi-scale modeling of dendritic alloy solidification to predict compositional and structural evolutions in dendritic alloy solidification. The model accounts for the transport phenomena occurring on the macroscopic (system) scale as well as the grain nucleation and growth over various microscopic length scales. The proposed model generalizes a previous multi-scale/-phase model Wang and Beckermann (1993) by including liquid melt convection and solid phase transport. The macroscopic transport equations for the solid and the interdendritic and extradendritic liquid phases are derived using the volume averaging technique. The resulting model equations are supplemented by constitutive relations for the interfacial transfer terms. Finally, the model is applied to investigate equiaxed dendritic solidification of an $\mathrm{Al}-4 \mathrm{wt} \% \mathrm{Cu}$ alloy in a rectangular cavity. For the first time, quantitative results for the dendritic microstructure evolution in the presence of melt convection and solid movement are obtained. The effects of crystal sedimentation on macrosegregation as well as the grain size distribution are illustrated.

The solidification of glass has less significance in the processes. Thus, there are few studies on this subject. In one study, Nishioka et al. (1990) investigated the solidification of glass powder with simulated high-level radioactive waste during hydrothermal hot-pressing. 


\section{EXPERIMENTAL INVESTIGATION}

Among the decontamination and recyching methods used to treat radioactively contaminated scrap metals (RSM), the melt refining/slugging is the most feasible low-cost option. The recycling procedures that involve melting usually include the following steps: -1$)$ pretreatment, which includes segregation, size reduction, and compacting; 2) melting the RSM with slag agents; and 3) separating and solidifying the metal and slag phases. The transfer and distribution of radionuclides in the melting and solidification process directly determine the efficiency of the decontamination.

\subsection{CHARACTERIZATION PROCEDURES}

In the characterization process implemented as part of this project, radionuclide transfer and distribution behaviors were analyzed using a scanning electron microscope/electron diffractive $\mathrm{X}$-ray (SEM/EDX) system. This process involved the following procedures:

- Weighing and analyzing the raw metal material and radionuclide surrogate, the crucible, and its cap, respectively, before melting;

- Mixing the metallic materials and cesium chloride and then loading them into the ceramic crucible, which was covered by a ceramic cap. The charged crucible was put into the helium resistance furnace chamber, and after a vacuum had been applied to the chamber, it was filled with helium gas (this repeated several times to reduce the resident air);

- Programming the furnace controller to the required heating and cooling rates and setting the holding time at the maximum temperature and the gas and water cooling flow rates;

- Heating the crucible at the rate of $15^{\circ} \mathrm{C} / \mathrm{min}$ to the operating temperature and holding it for one hour to melt the charge followed by cooling the crucible in the furnace at the rate of $14^{\circ} \mathrm{C} / \mathrm{min}$ to allow the melted charge to solidify into an ingot under nonoxidizing conditions;

- Analyzing the composition and appearance of surface of the ingot, crucible, and cap with SEM/EDX; and

- Cutting the ingot along vertical section at center, griding and polishing the section and analyzing the composition and microstructure of the cross section.

A schematic drawing of the characterization process is shown in Figure 1. The procedures are shown schematically in Figure 2. 


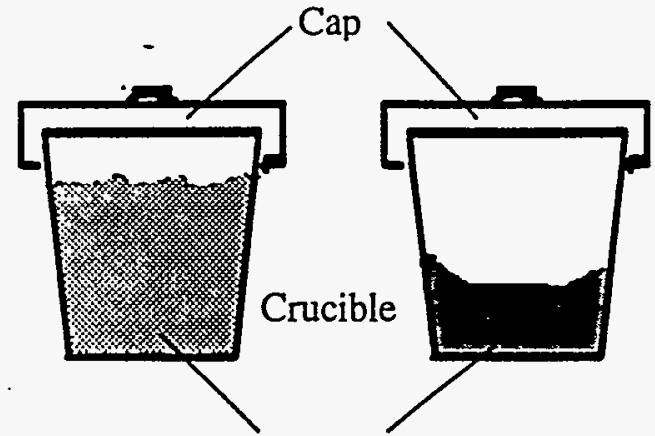

Charges

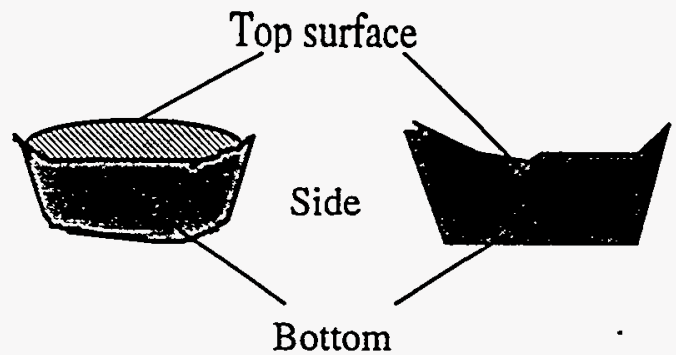

Appearance of ingot

Cross-section

Melted

Figure 1. Schematic drawing of the characterization process.

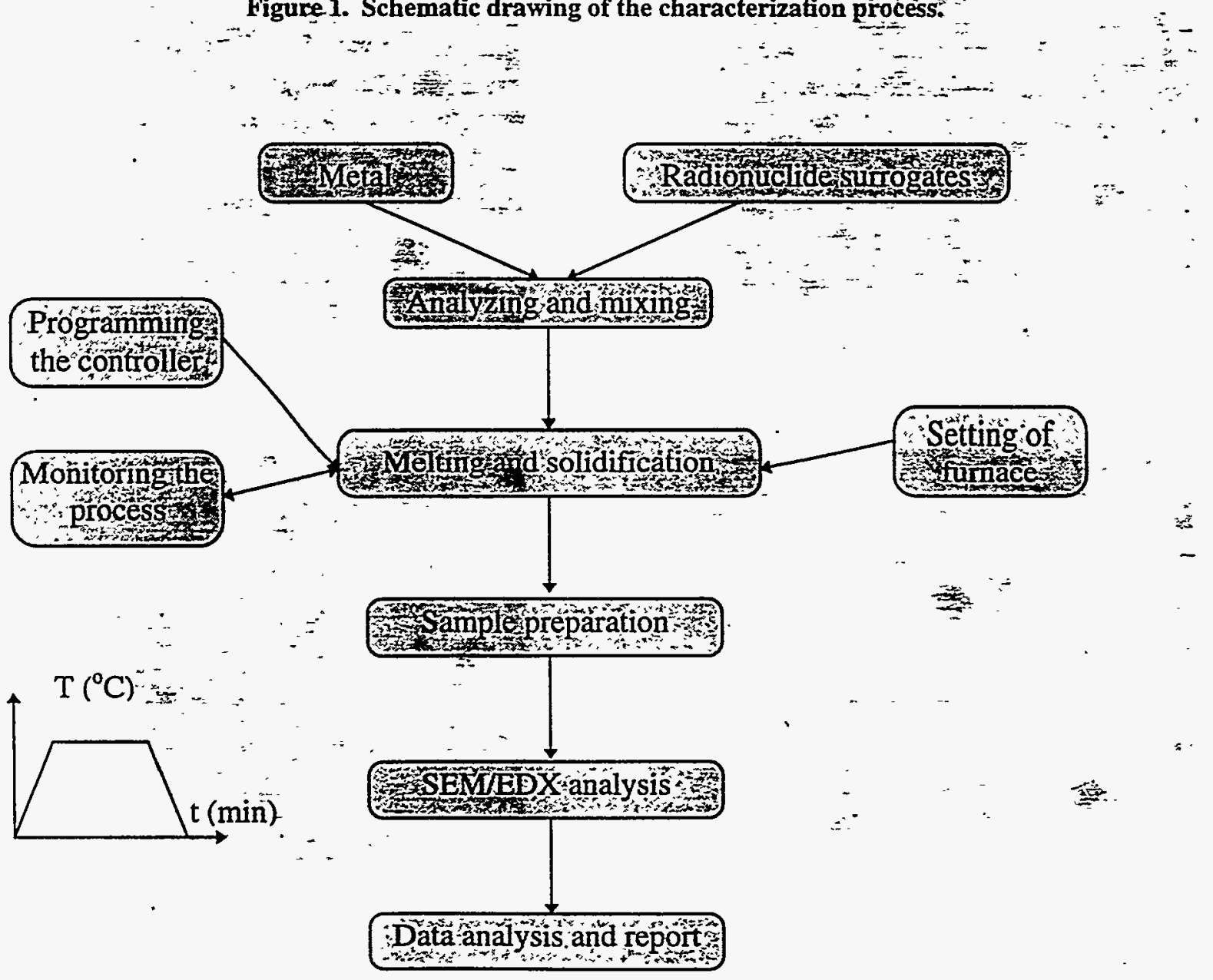

Figure 2. Flow chart of the characterization process. 
Only a limited number of test programs have used surrogates to simulate the distribution of radioactive nuclides during the melting refining and metal ingot. The surrogates used to simulate plutonium oxide and transuranic oxide distribution include $\mathrm{HfO}_{2} ; \mathrm{UO}_{2}$; and rare earth oxides of dysprosium, terbium, neodymium, cerium and ytterbium (Worcester et al. 1993). Cerium (IV) oxide and cesium chloride have been used in surrogate waste in plasma hearth processes for mixed waste treatment application. ${ }^{49}$ (Hassel et al. 1994) In this project, cerium (IV) oxide and cesium chloride were used as radionuclide surrogates. Cerium (IV) oxide $\left(\mathrm{CeO}_{2}\right)$ has a density of $7132 \mathrm{~kg} / \mathrm{m}^{3}$ and a melting temperature of $2600^{\circ} \mathrm{C}$. Cesium chloride $(\mathrm{CsCl})$ has a density of 3988 $\mathrm{kg} / \mathrm{m}^{3}$ and melting and boiling points of $645^{\circ}$ and $1290^{\circ} \mathrm{C}$, respectively.

\subsection{ANCILLARY EQUIPMENT}

Two types of ancillary equipment were used in this project: a resistance furnace and SEM/EDX analysis system. They are described in this section.

\subsubsection{Resistance Furnace}

The melting and solidification process was conducted in a $20 \mathrm{KVA}$ ASTRO laboratory furnace that has a programmable automatic power and temperature controller and can be operated under a vacuum or inert and dry reducing atmospheres with pressure capabilities to 15 psig positive to full vacuum. Its maximum operating temperature was $2300^{\circ} \mathrm{C}$. The heating and cooling speeds and holding time could be programmed and precisely controlled. These features allowed for the characterization of the melting and solidification process under well-defined operating conditions, facilitating the study of each operating parameter. A photograph of the furnace is presented in Figure 3. 


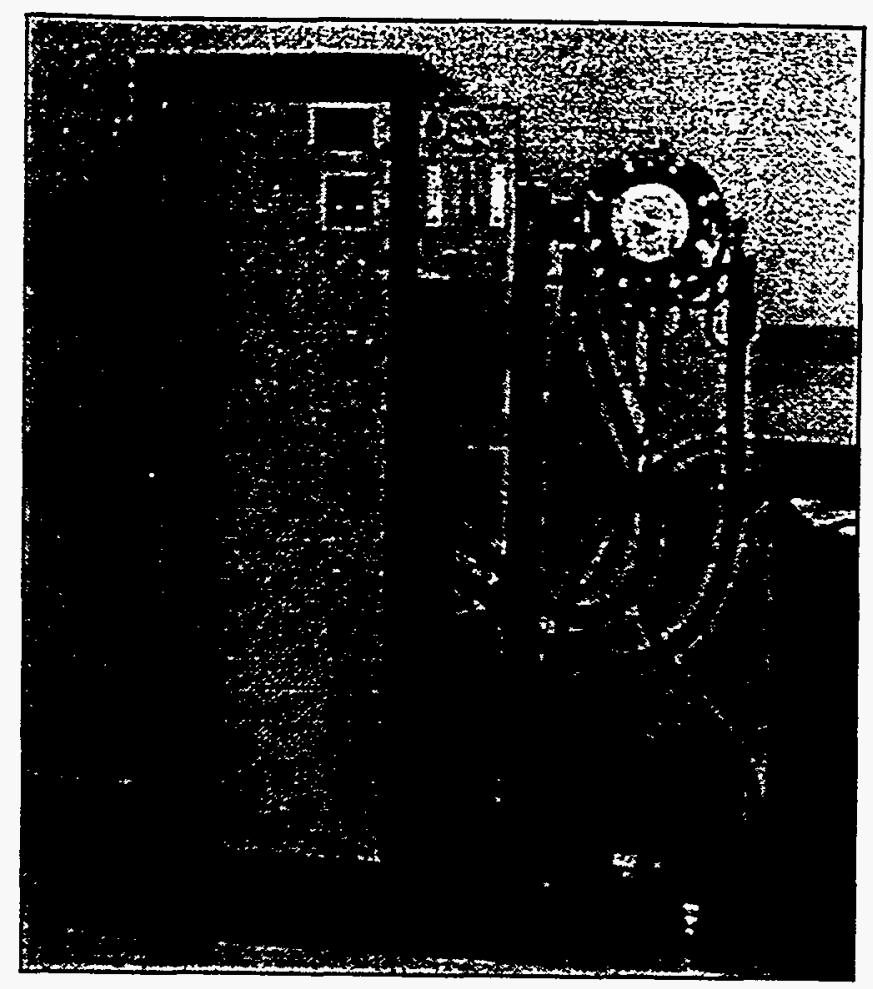

Figure 3. Photograph of the furnace.

\subsubsection{SEM/EDX}

A JSM-35CF high-performance scanning microscope with an Energy Disperse Type X-ray Spectrometer and Image Analyzer, as shown in Figure 4, was used. It had a scintillatorphotomultiplier detector system complete with a preamplifier and a collector. 


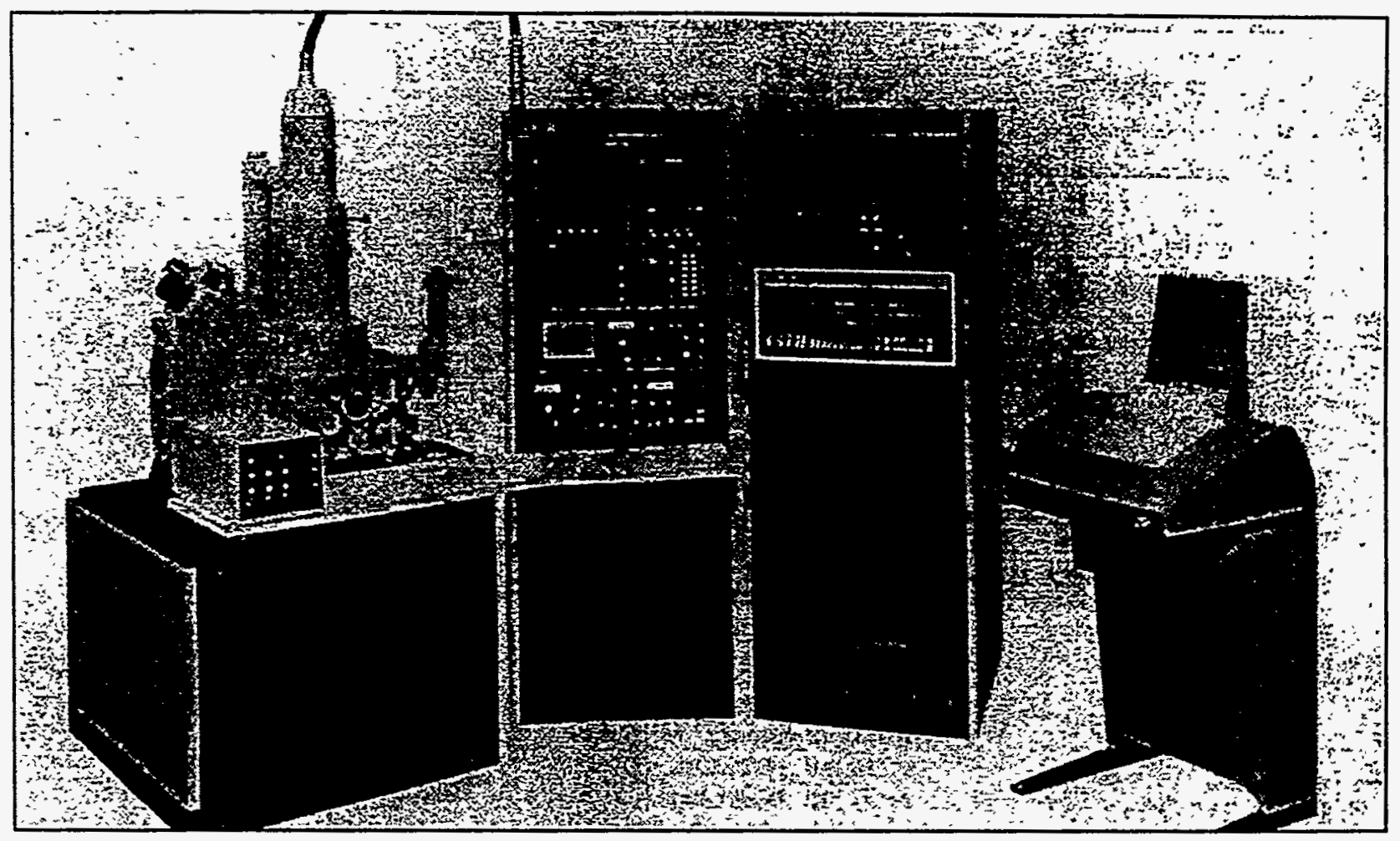

Figure 4. SEM/EDX system.

The EDX attachment allowed microscope expansion to a multichannel microanalyzer for X-ray elemental analysis of micro-regions with a attainable sensitivity of 0.5 percent.

The Image Analyzer (Micro-Particle Aralyzer) had the ability to calculate the area percentage of metallic precipitates and the number, diameter, and area of particles from scanning images. The direct analysis of video signals greatly reduced measurement time and minimized error. Prompt data processing was ensured by special logic circuits and a built-in microprocessor.

This method is mainly used to characterize metallurgical phenomena such as segregation and oxide particulate distribution. 


\subsection{CHARACTERIZATION RESULTS}

The characterization process, was conducted at the Hemispheric Center for Environmental Technology (HCET) located on the campus of Florida International University. Five test melts were characterized. The melts and melting conditions are listed in Table 4 . The weight changes are also shown in this table. In all the tests, the metal material with radionuclide surrogates were melted and solidified in a $20 \mathrm{KVA}$ ASTRO laboratory furnace with a helium atmosphere. A SEM/EDX analysis was performed to detect radionuclide surrogate distribution in the metal ingot and other surfaces after the melting and solidification cycle.

Table 4.

Melt Ingredients, Melting Conditions, and Weight Changes

\begin{tabular}{|c|c|c|c|c|c|}
\hline Number & 1 & 2 & 3 & 4 & 5 \\
\hline Metallic material & $\mathrm{Al}: 100 \%$ & Al: $100 \%$ & $\begin{array}{l}\mathrm{Al}: 95.70 \% \\
\mathrm{Mg}: 4.30 \%\end{array}$ & $\begin{array}{l}\mathrm{Al}: 95.70 \% \\
\mathrm{Mg}: 4.30 \%\end{array}$ & $\begin{array}{ll}\mathrm{Cu}: & 86.32 \% \\
\mathrm{Mg}: & 6.85 \% \\
\mathrm{Al}: & 4.85 \% \\
\mathrm{Si}: & 1.34 \% \\
\end{array}$ \\
\hline Weight & $10.00 \mathrm{~g}$ & $10.00 \mathrm{~g}$ & $10.00 \mathrm{~g}$ & $10.00 \mathrm{~g}$ & $20.00 \mathrm{~g}$ \\
\hline Cesium chloride & $0.10 \mathrm{~g}$ & $0.20 \mathrm{~g}$ & $0.50 \mathrm{~g}$ & $0.50 \mathrm{~g}$ & $0.40 \mathrm{~g}$ \\
\hline Weight before melting & $10.10 \mathrm{~g}$ & $10.20 \mathrm{~g}$ & $10.50 \mathrm{~g}$ & $10.50 \mathrm{~g}$ & $20.40 \mathrm{~g}$ \\
\hline Weight after melting & $9.90 \mathrm{~g}$ & --- & -- & $9.60 \mathrm{~g}$ & -- \\
\hline Operating temperature & $750^{\circ} \mathrm{C}$ & $750^{\circ} \mathrm{C}$ & $800^{\circ} \mathrm{C}$ & $900^{\circ} \mathrm{C}$ & $1150^{\circ} \mathrm{C}$ \\
\hline Heating rate & $5^{\circ} \mathrm{C} / \mathrm{min}$ & $5^{\circ} \mathrm{C} / \mathrm{min}$ & $15^{\circ} \mathrm{C} / \mathrm{min}$ & $15^{\circ} \mathrm{C} / \mathrm{min}$ & $5^{\circ} \mathrm{C} / \mathrm{min}$ \\
\hline Cooling rate & $5^{\circ} \mathrm{C} / \mathrm{min}$ & $5^{\circ} \mathrm{C} / \mathrm{min}$ & $14^{\circ} \mathrm{C} / \mathrm{min}$ & $14^{\circ} \mathrm{C} / \mathrm{min}$ & $5^{\circ} \mathrm{C} / \mathrm{min}$ \\
\hline Holding time & $30 \mathrm{~min}$ & $30 \mathrm{~min}$ & $60 \mathrm{~min}$ & $60 \mathrm{~min}$ & $60 \mathrm{~min}$ \\
\hline
\end{tabular}

\subsubsection{Tests 1 and 2}

In Tests 1 and 2 , aluminium powder mixed with 1 and 2 percent cesium chloride was melted and solidified in the furnace. SEM analysis indicated that many cavities were present in the ingots (see Figures $5 \mathrm{a}$ and $5 \mathrm{~b}$ ). Cesium chloride $(\mathrm{CsCl})$ inclusions were not found. In Test 1, the melting process was not finalized; large holes existed in the bottom of the ingot (see Figure 5c). 


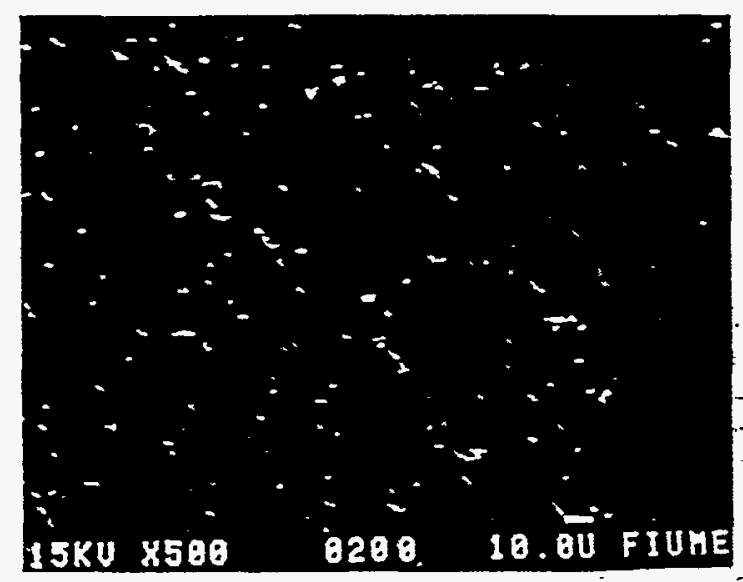

(a)

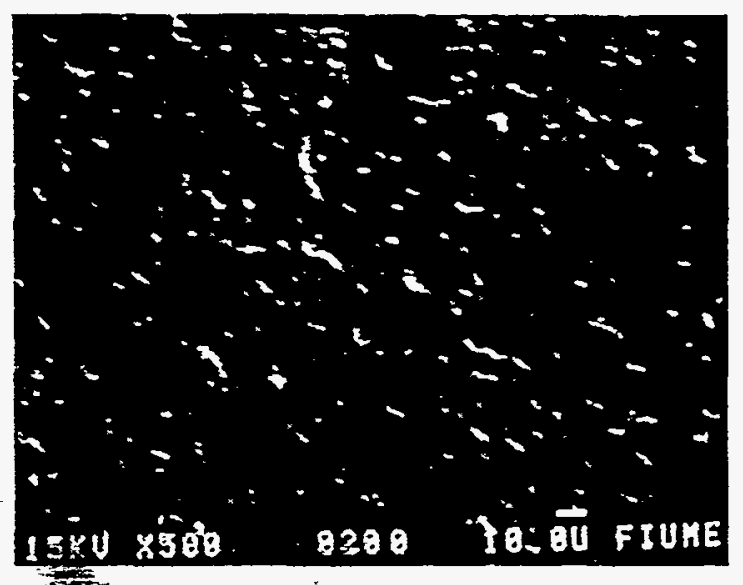

(b)

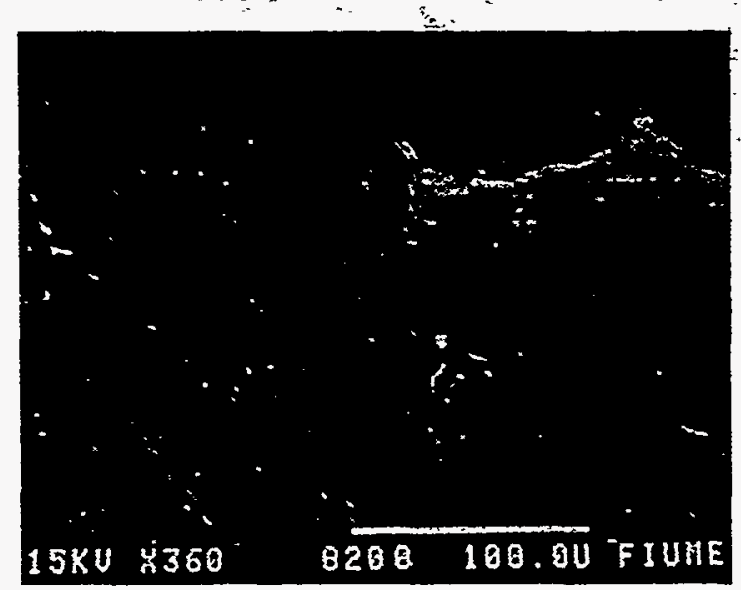

(c)

Figure 5. Structure of the ingots produced in Tests 1 and 2. (a) Cavities found in Test 1; (b) cavities found in Test 2; (c) large holes found in Test 1.

The composition of the ingots was analyzed with the EDX. The distributions of cesium and chlorine are shown in Table 5.

Table 5.

Distribution of Cesium and Chlorine in the Ingots Produced in Tests 1 and 2

\begin{tabular}{|c|c|c|c|c|c|c|c|}
\hline Test number & Element & Top & $\mathbf{3} \mathbf{~ m m}$ & $\mathbf{6 ~ \mathbf { ~ m }}$ & $\mathbf{9} \mathbf{~ m m}$ & $\mathbf{1 2} \mathbf{~ m m}$ & Bottom \\
\hline Test 1 & $\mathrm{Cs}$ & 0.19 & 0.12 & 0.00 & 0.08 & & 0.08 \\
\hline & $\mathrm{Cl}$ & 0.18 & 0.15 & 0.22 & 0.28 & & 0.23 \\
\hline Test 2 & $\mathrm{Cs}$ & 0.23 & 0.00 & 0.21 & 0.00 & 0.00 & 0.26 \\
\hline & $\mathrm{Cl}$ & 0.17 & 0.27 & 0.27 & 0.30 & 0.00 & 0.20 \\
\hline
\end{tabular}


The microstructures of the gray powder are shown in Figure 6. The globe is composed of pure aluminum, whereas the other region consists of a mixture of aluminum and cesium chloride. The content of cesium and chlorine in the powder is much higher than that in the ingot.

It appears that $\Pi$ cesium and chlorine are found mainly in the powder, 2) the content of cesium and chlorine in the ingot is very low, and 3) most of the cesium and chlorine are located in the region close to the surface of the ingot.

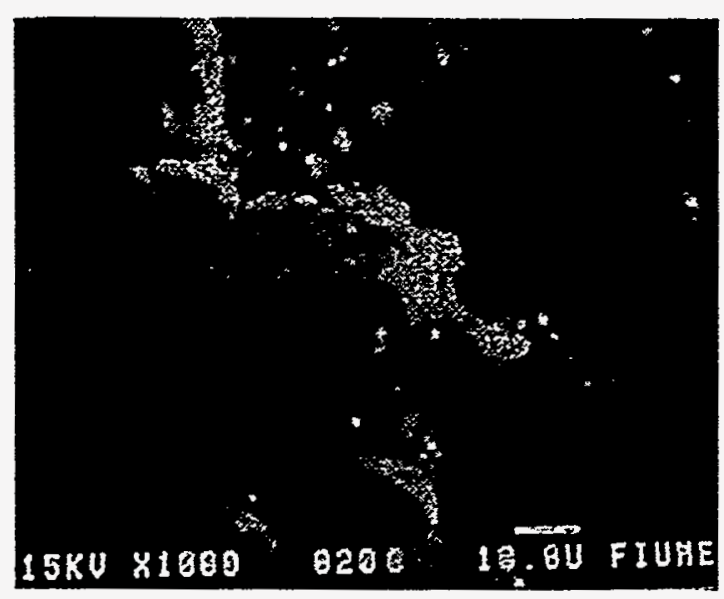

(a)

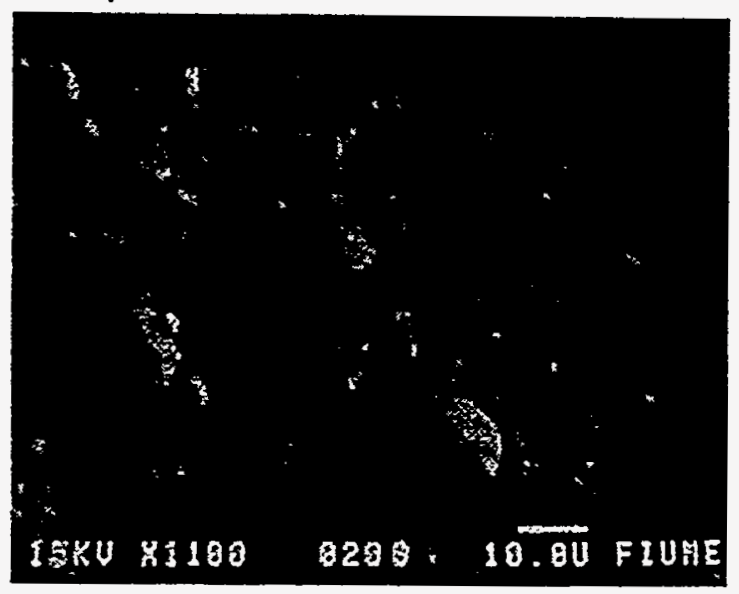

(b)

Figure 6. Structures of the gray powder residual in the crucible. (a) Test 1; (b) Test 2.

\subsubsection{Tests 3 and 4}

Inasmuch as the results of Tests 1 and 2 , in which a smaller percentage of cesium chloride were applied, indicated that it was difficult to identify the cesium chloride in the ingot, another two tests (Tests 3 and 4) of aluminium alloy with 5 percent cesium chloride were conducted applying different operating temperatures. The aluminium alloy number was 5083, which had 95.7 percent $\mathrm{Al}$ and 4.30 percent $\mathrm{Mg}$.

In Test 3, the materials were melted at the rate of $15^{\circ} \mathrm{C} / \mathrm{min}$ with a heating temperature of $800^{\circ} \mathrm{C}$, a holding time of 60 minutes, and a cooling rate of $14^{\circ} \mathrm{C} / \mathrm{min}$. The charge melted and solidified into an ingot with no powder formation. After solidification, the ingot was difficult to remove from the crucible, and the crucible broke after the ingot was removed.

The entire surface (side, top, and bottom) of the ingot was analyzed by SEM, and photomicrographs were taken (see Figure 7). A large quantity of cesium chloride was found on the bottom and side surfaces of the ingot. The distribution of cesium chloride on the surfaces was not uniform, however, as shown in Figure 8. No cesium chloride crystals could be found on the top surface of the ingot (see Figure 9), but some cesium and chlorine elements (less than 3 percent) were detected by EDX (see Figure 10). Further SEM analysis of the cross section of the ingot indicated that no cesium or chlorine were present. This can be attributed to the melting process; the cesium chloride and the aluminum alloy were mixed well before being put into the 
furnace; thus, no stirring was used. Because of the higher density of the cesium chloride, it falls to the bottom of the crucible during the melting process. In the solidification process, the aluminum alloy solidifies first due to its higher melting temperature. The lump of solidified aluminum falls and pushes the cesium chloride flow along the side wall of the crucible.

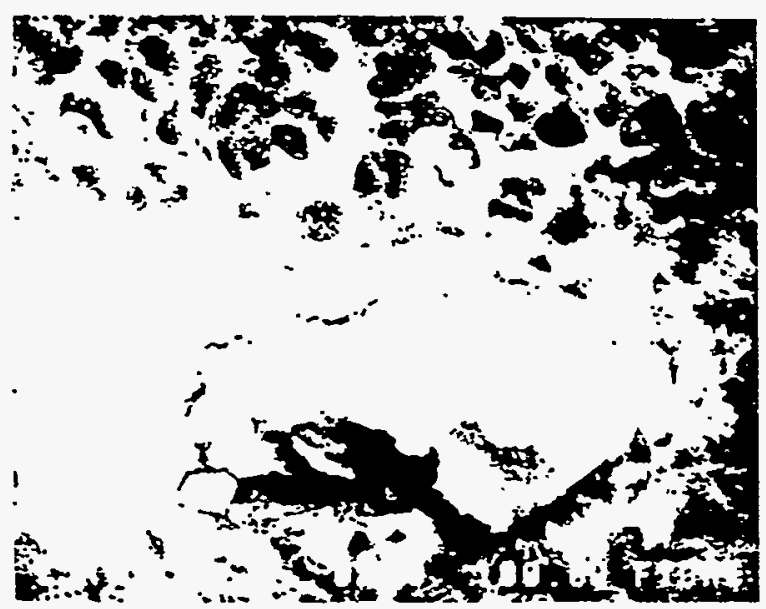

(a)

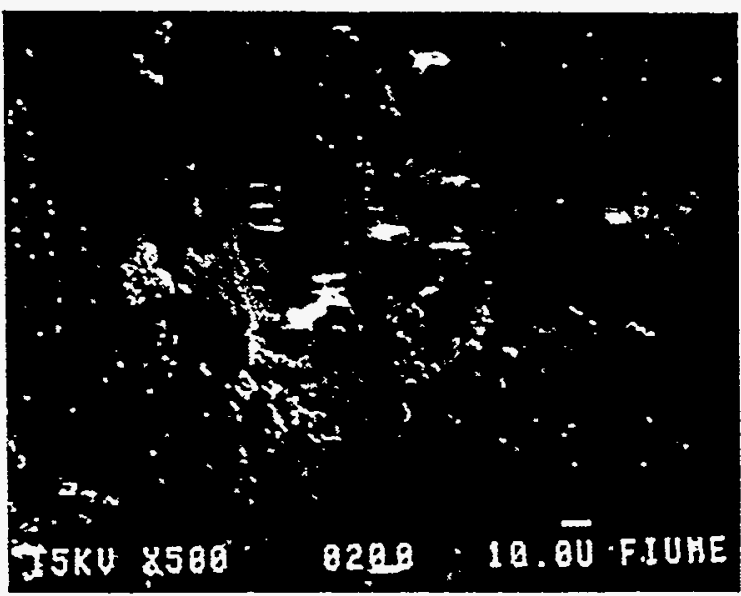

(c)

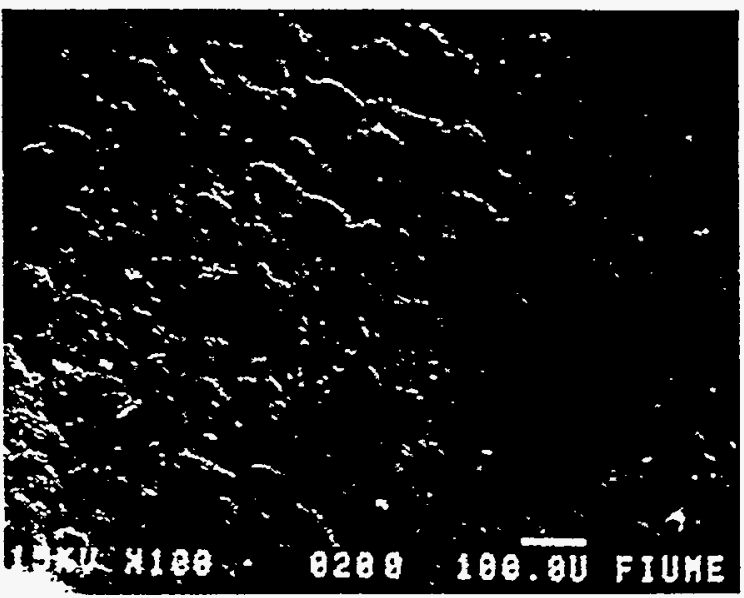

(b)

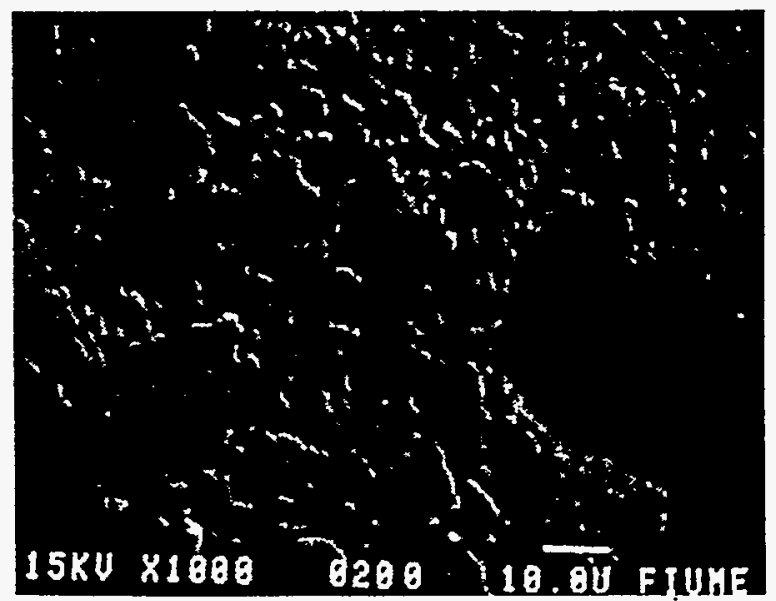

(d)

Figure 7. Microphotographs of the bottom and side surfaces of the ingot produced in Test 3 . The bright areas represent $\mathrm{CsCl}$ crystals; other areas, dendrities of proeutetic aluminum surrounded by eutetic mixture of aluminum and silicon. Figures (a)-(c) show the bottom surface; (d), the side surface. 


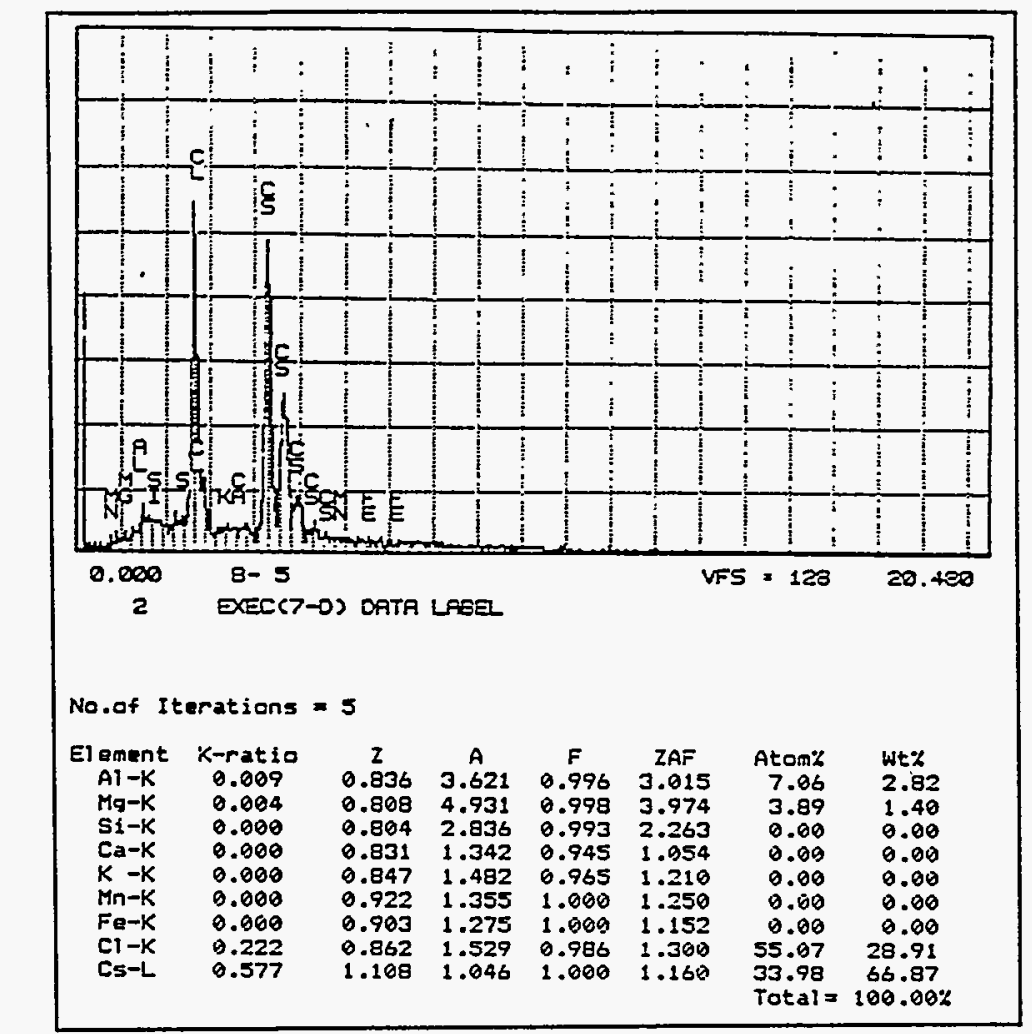

Figure 8. Local composition and EDX spectrograms of the bottom surface of the ingot of Test 3 .

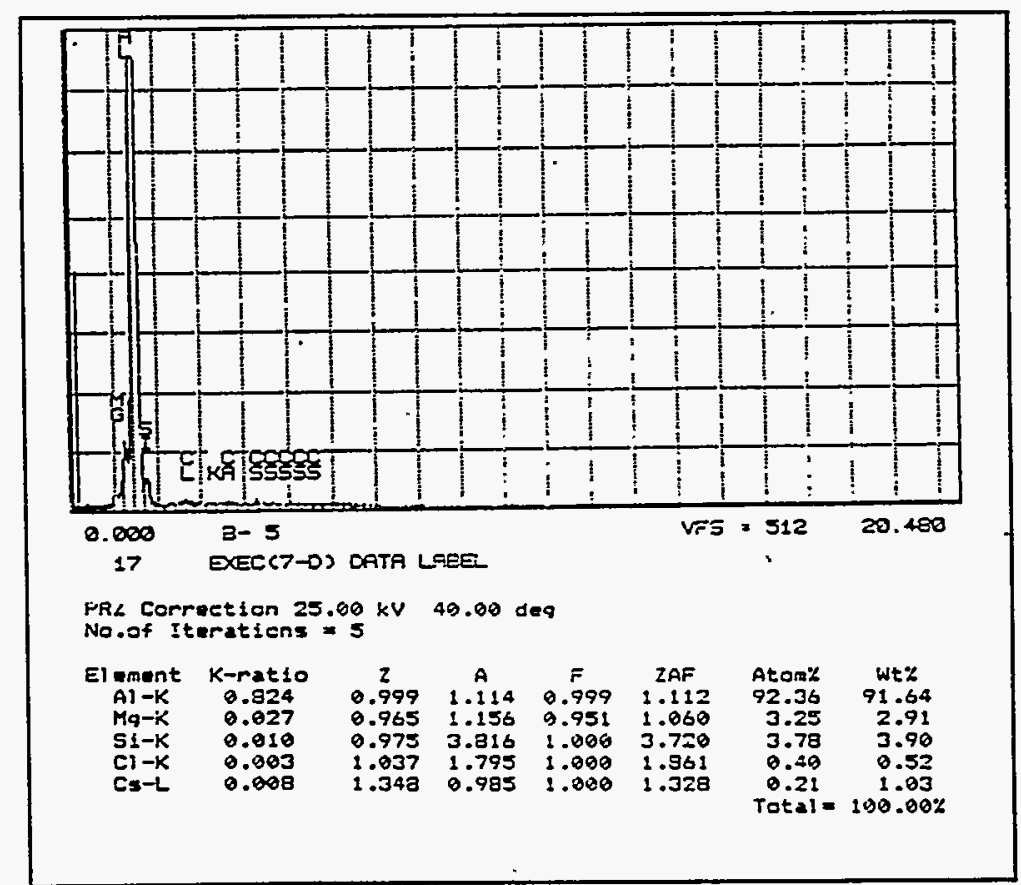

Figure 9. Local composition and EDX spectrograms of the top surface of the ingot of Test 4 . 


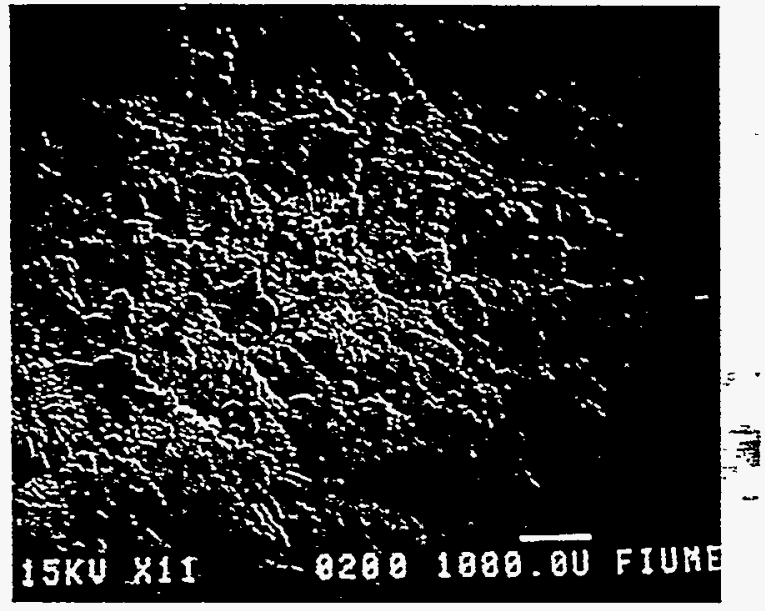

(a)

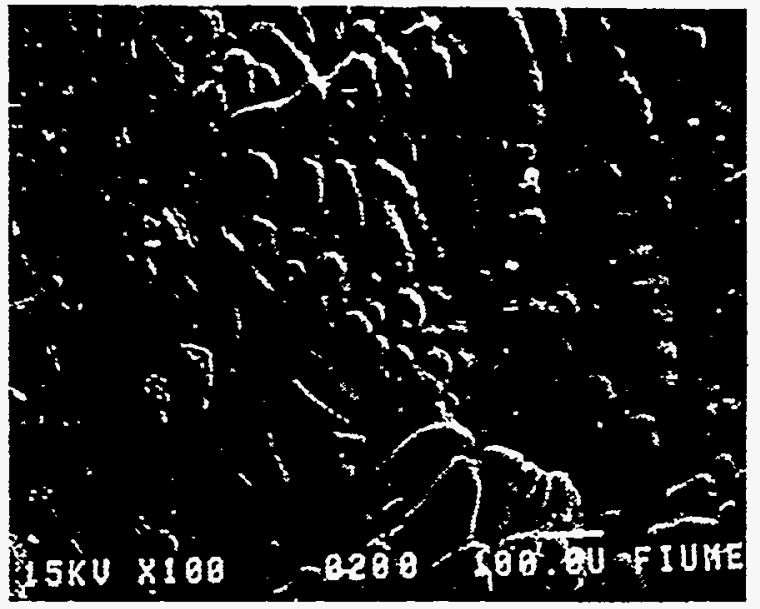

(b)

Figure 10. Microphotographs of the top surface of the ingot produced in Test 3 (dendrities of proeutetic aluminum surrounded by eutetic mixture of alưminum and silicon).<smiles>[13CH3]</smiles>

In Test 4, after melting and solidifying; the weights of the charge, crucible, and cap were. changed, as specified in Table 6 :

$$
\text { Weight Changes in Test } 4
$$

\begin{tabular}{|c|c|c|c|c|c|}
\hline & \multicolumn{2}{|c|}{ Charge } & \multirow{2}{*}{ Crucible } & \multirow{2}{*}{ Cap } & \multirow{2}{*}{ Total } \\
\hline & Al alloy & $\mathrm{CsCl}$ & & & \\
\hline \multirow{2}{*}{ Before melting } & 10.000 & 0.500 & \multirow[b]{2}{*}{9.573} & \multirow[b]{2}{*}{0.140} & \multirow[b]{2}{*}{20.397} \\
\hline & \multicolumn{2}{|c|}{10.500} & & & \\
\hline $\begin{array}{l}\text { After } \\
\text { solidification }\end{array}$ & \multicolumn{2}{|c|}{9.598} & 10.138 & 0.167 & 19.906 \\
\hline
\end{tabular}

The weight of the charge was reduced $(0.902 \mathrm{~g})$. The weight of the crucible and the cap were increased 0.385 and 0.027 , respectively. This indicates that some of the charge was transferred into the crucible and cap, and some escaped from the crucible. Thus, the total weight of the charge, the crucible, and the cap was reduced $0.491 \mathrm{~g}$.

The appearance of the bottom surface of the ingot produced in Test 4 is shown in Figure 11 . Three different layers (A, B, and C) can be observed. Their composition is shown in Table 7. 
Table 7.

Composition of the Bottom Surface of the Ingot Produced in Test 4

\begin{tabular}{|c|c|c|c|c|c|c|}
\hline \multicolumn{2}{|c|}{ Position } & Al & Mg & Si & Cl & Cs \\
\hline $\mathrm{A}$ & wt \% & 23.98 & 6.45 & 7.19 & 4.55 & 7.89 \\
\hline & tom \% & 24.33 & 3.55 & 7.00 & 3.51 & 1.61 \\
\hline $\mathrm{B}$ & wt \% & 61.39 & 10.75 & 9.55 & 2.21 & 12.93 \\
\hline & tom \% & 68.99 & 13.41 & 10.33 & 1.89 & 2.95 \\
\hline $\mathrm{C}$ & wt \% & 49.05 & 0.00 & 0.80 & 5.67 & 44.49 \\
\hline & tom \% & 77.66 & 0.00 & 1.22 & 6.83 & 14.49 \\
\hline
\end{tabular}

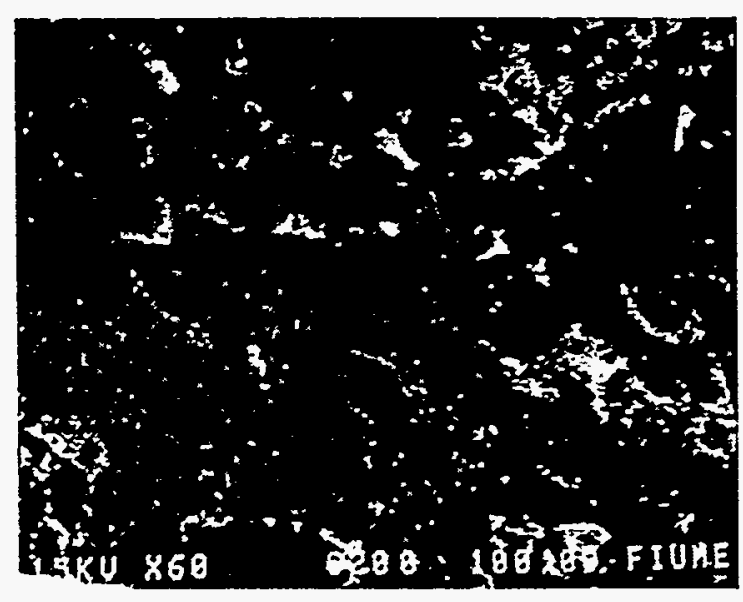

(a)

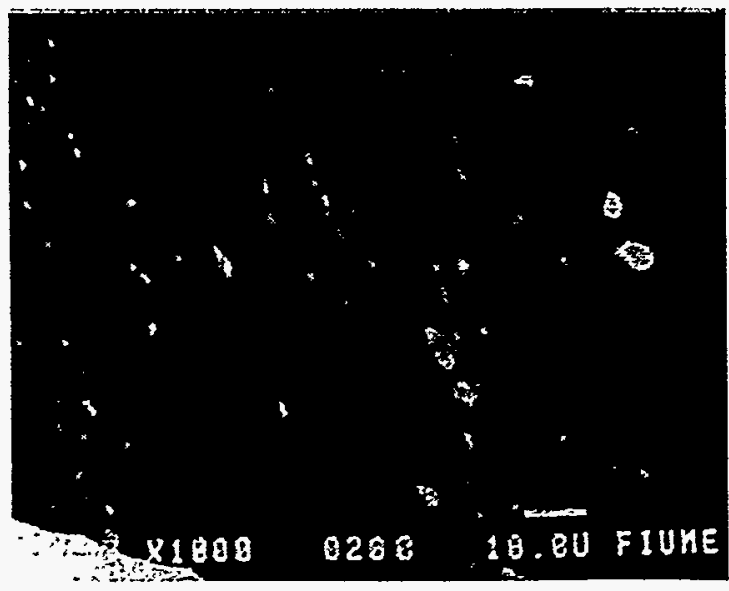

(c)

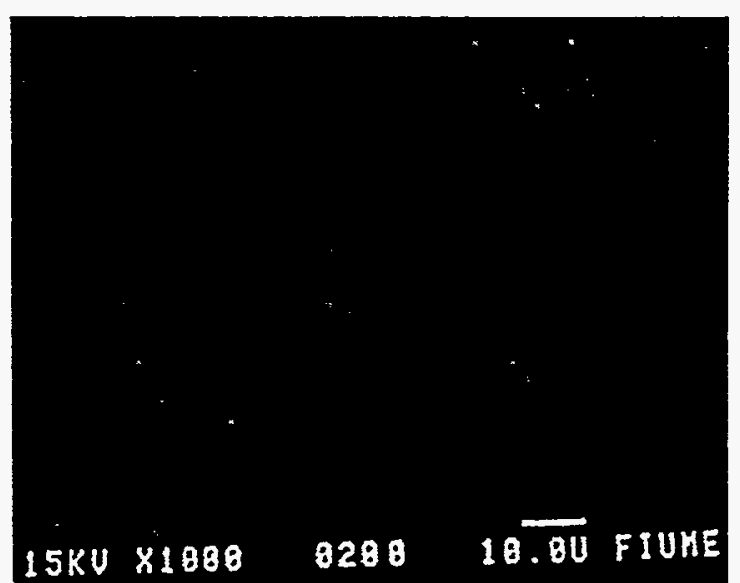

(b)

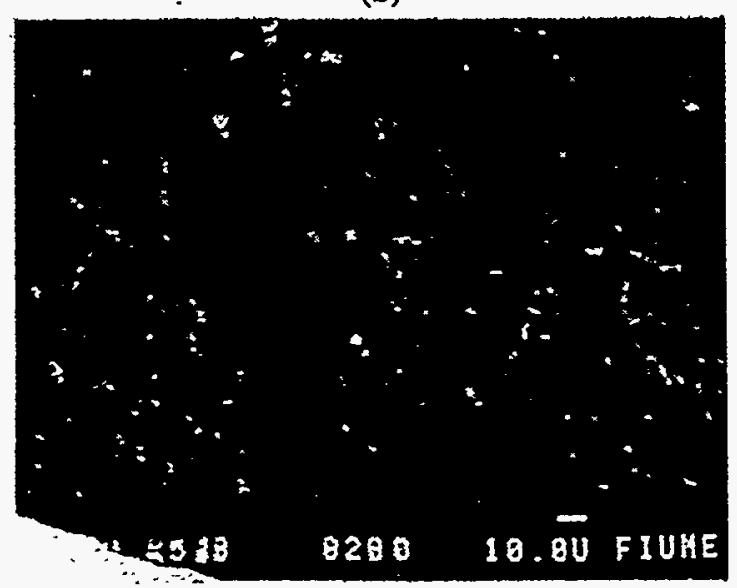

(d)

Figure 11. Structure of the bottom surface of the ingot produced in Test 4. (a) Three-layer structure; (b) structure of layer $\mathrm{A}$ (high $\mathrm{Mg}$ content); (c) structure of layer $\mathrm{B}$ (oxides and $\mathrm{CsCl}$ ); (d) structure of layer $\mathrm{C}$ ( $\mathrm{CsCl}$ and dentrites-eutectic). 
Layer A, the outer layer of the ingot, which had contact with the inner wall of the crucible, was found to contain more magnesium and some cesium and chlorine (for typical composition and spectrogram, see Figure 12a). Layer B, mid-layer with rich oxides and $\mathrm{C}_{s} \mathrm{Cl}$. Layer $\mathrm{C}$, the inner layer, contained more cesium and chlorine without magnesium (for typical composition and spectrogram, see Figure 12b). The side of the ingot was similar in composition to the bottom surface (see Figure 13). 


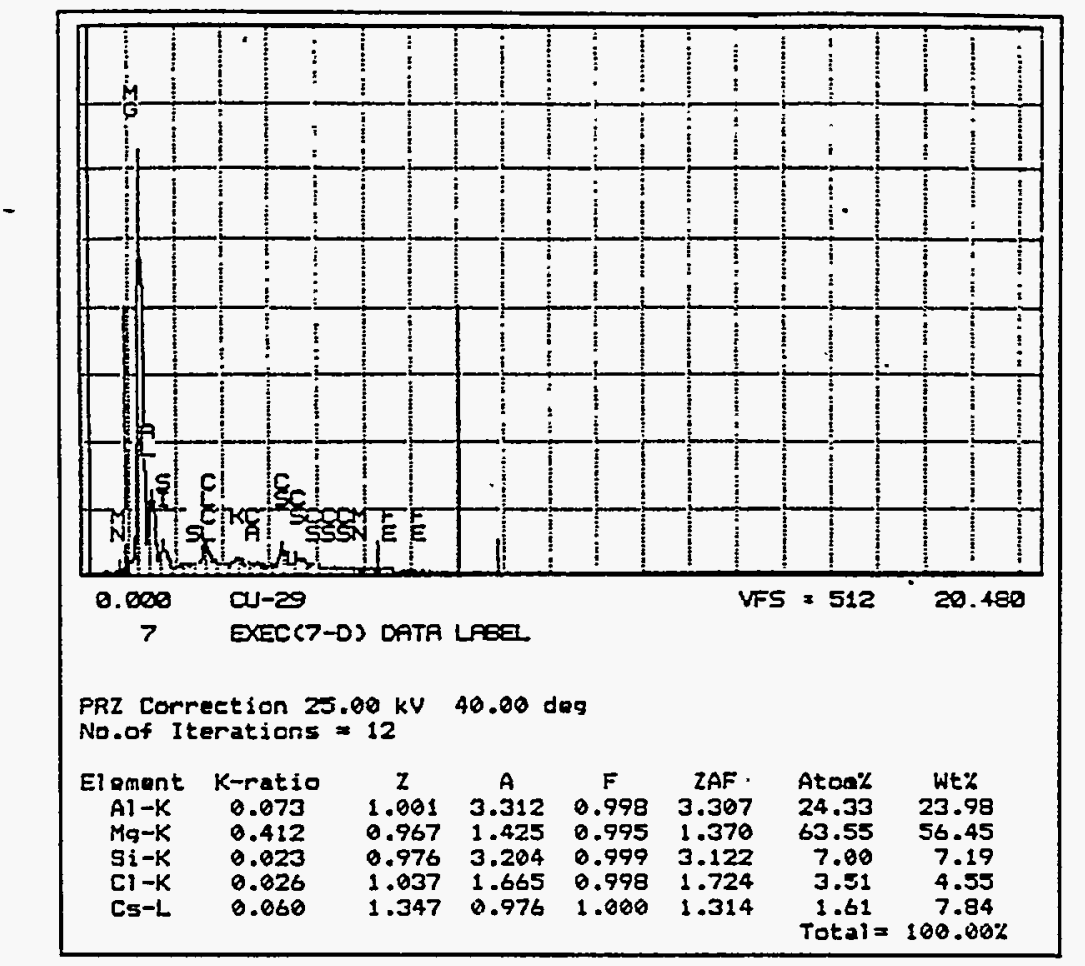

(a)

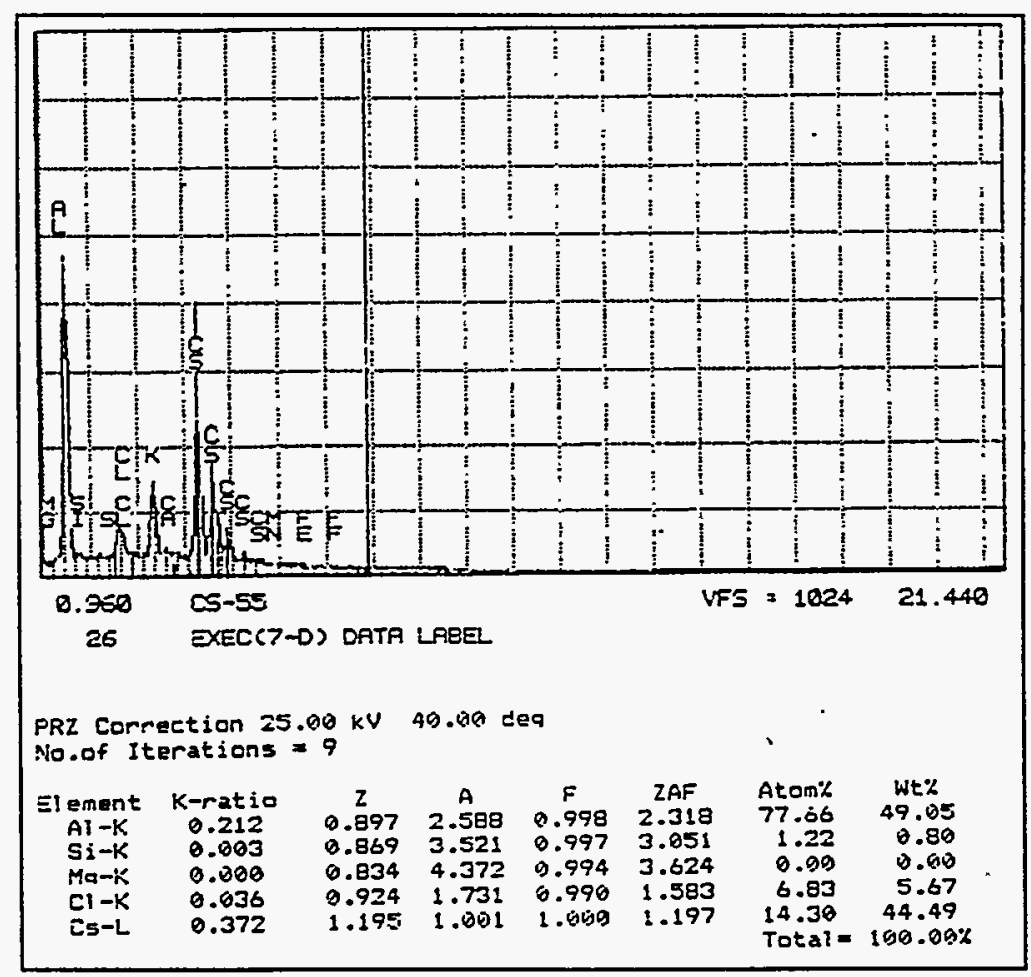

(b)

Figure 12. Local composition and EDX spectrograms of the bottom surface of the ingot produced during Test 4 . (a) Layer $A$; (b) Layer C. 


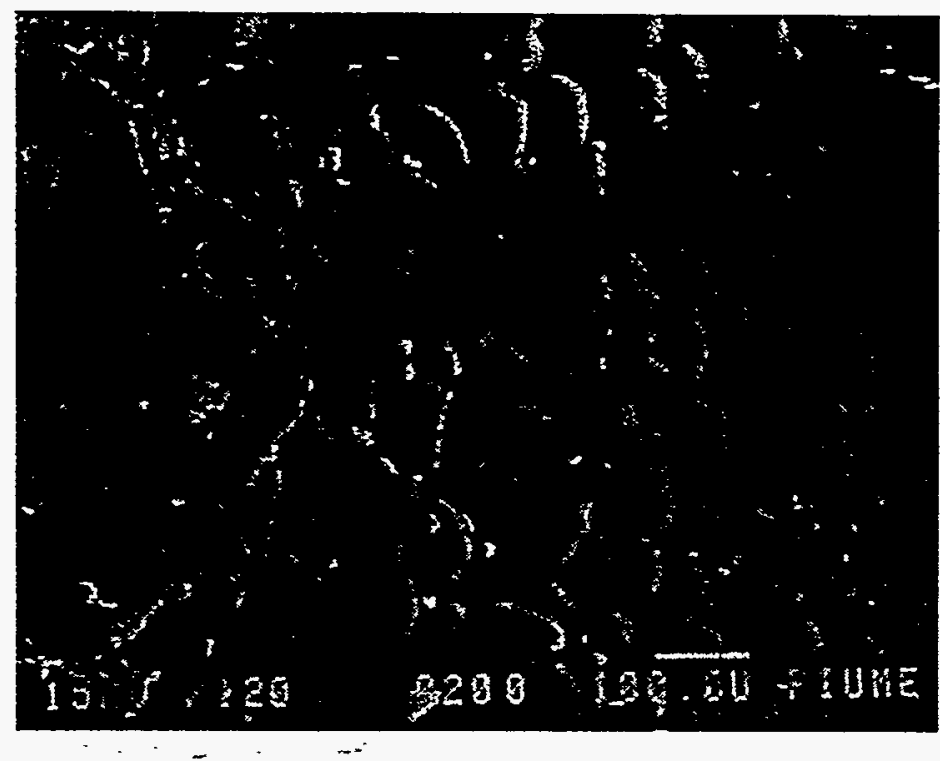

- Figure 13. Structures of the side surface of the ingot produced in Test 4.

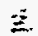

However, the top surface of the ingot is very different from the bottom surface. On the metallic ingot, there is a layer of glass-like material (see Figure 14). In only a few areas, cesium and chlorine can be found. In most areas, no cesium is detected (for the typical composition and spectrogram, see Figure 15):

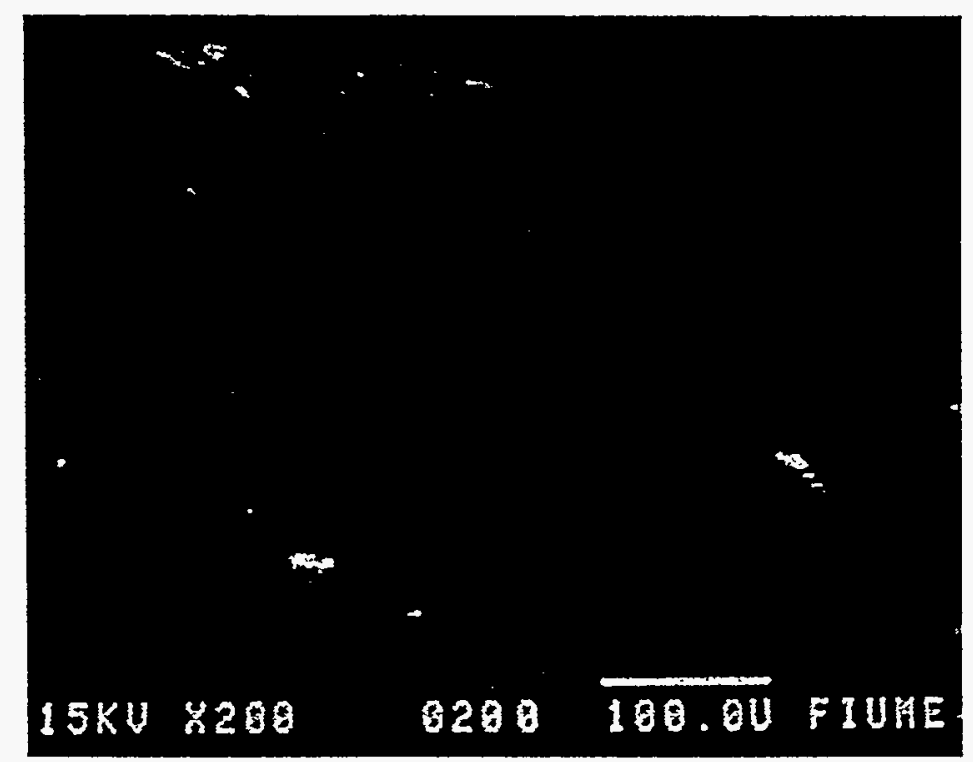

Figure 14. Structures of the top surface of the ingot produced in Test 4. 


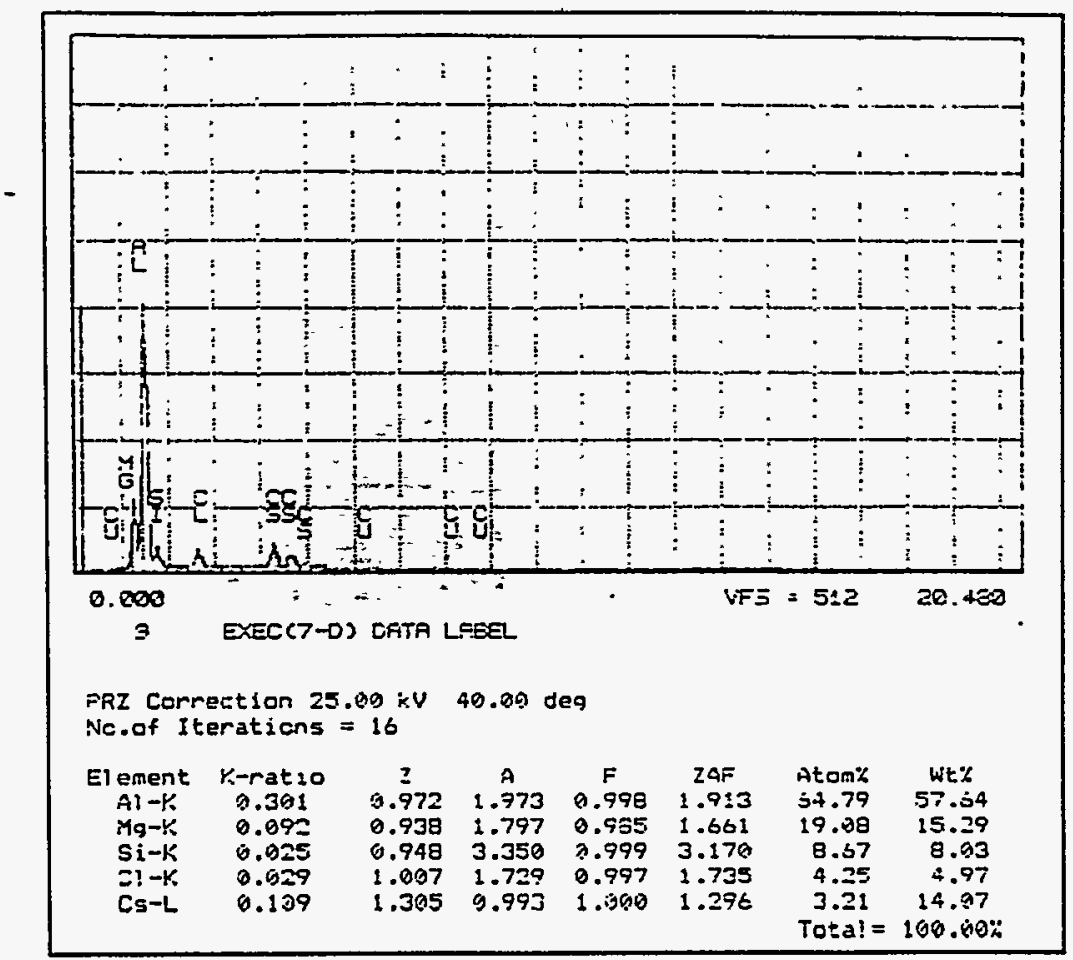

(a)

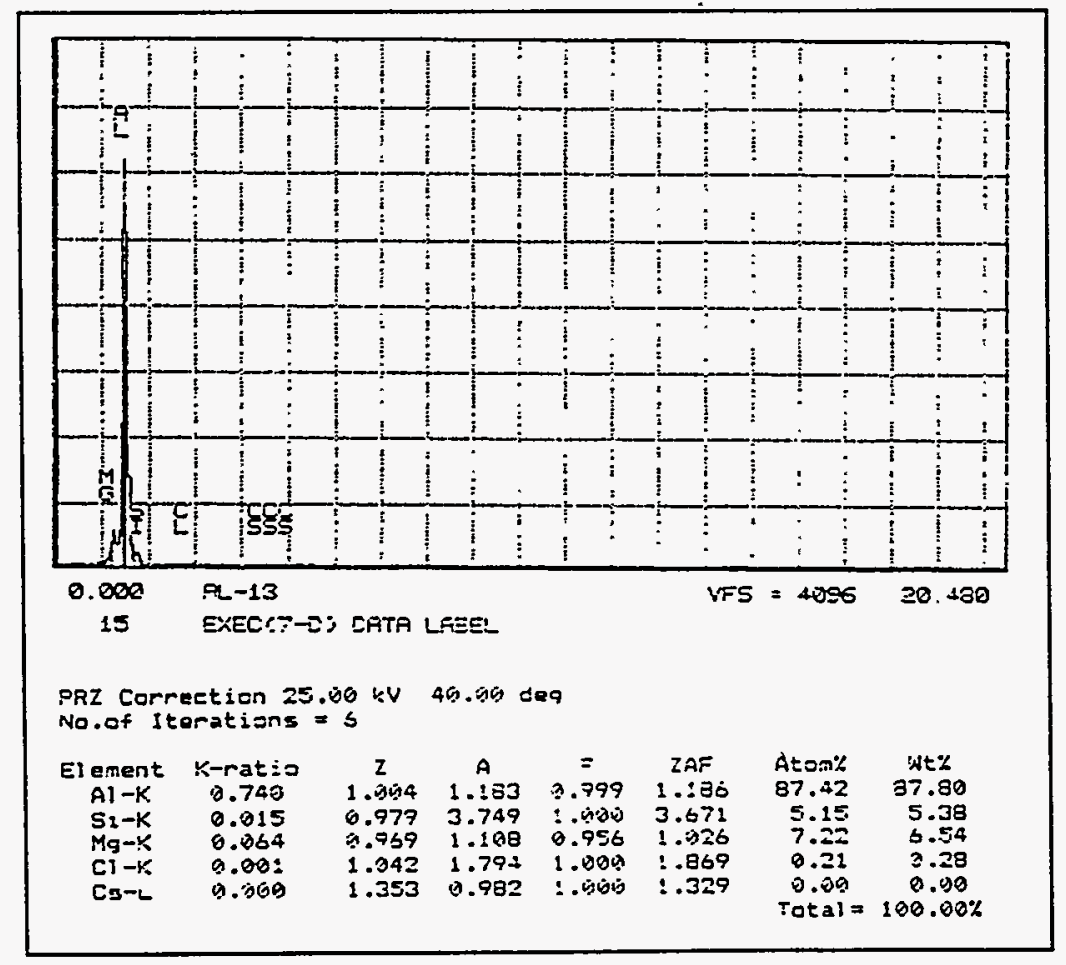

(b)

Figure 15. Local composition and EDX spectrograms of the top surface of the ingot produced in Test 4. (a) Area rich in $\mathrm{Cs}$ and $\mathrm{Cl}$.; (b) another area with little $\mathrm{Cs}$ or $\mathrm{Cl}$. 
The microstructure of the cross section (vertical section) of the ingot is shown in Figure 16. It consists of $\alpha$-phase (solid solution of $\mathrm{Si}, \mathrm{Mg}$ in Al) plus an eutectic mixture $\left(\alpha+\mathrm{Mg}_{2} \mathrm{Si}\right)$ plus an intermetallic compound $\left(\mathrm{Fe}_{2} \mathrm{Si}_{3} \mathrm{Al}_{15}\right)$. The composition and spectrogram of different areas are presented as Figure 17. Little visible cesium chloride and cesium and some chlorine can be found in the cross section..

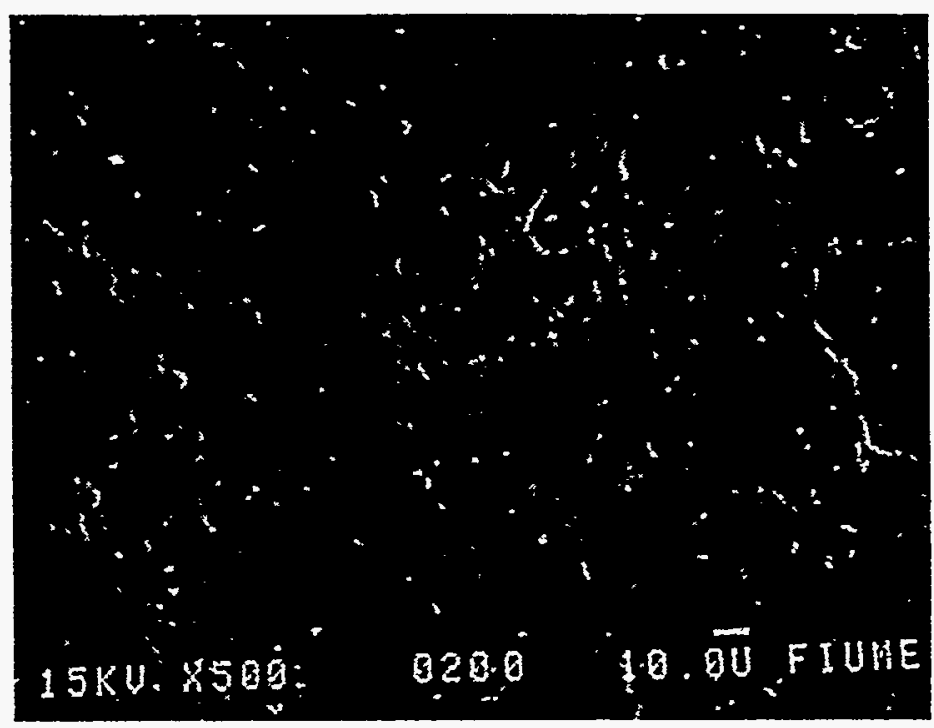

Figure 16. Structures of the cross section of the ingot produced in Test 4. 


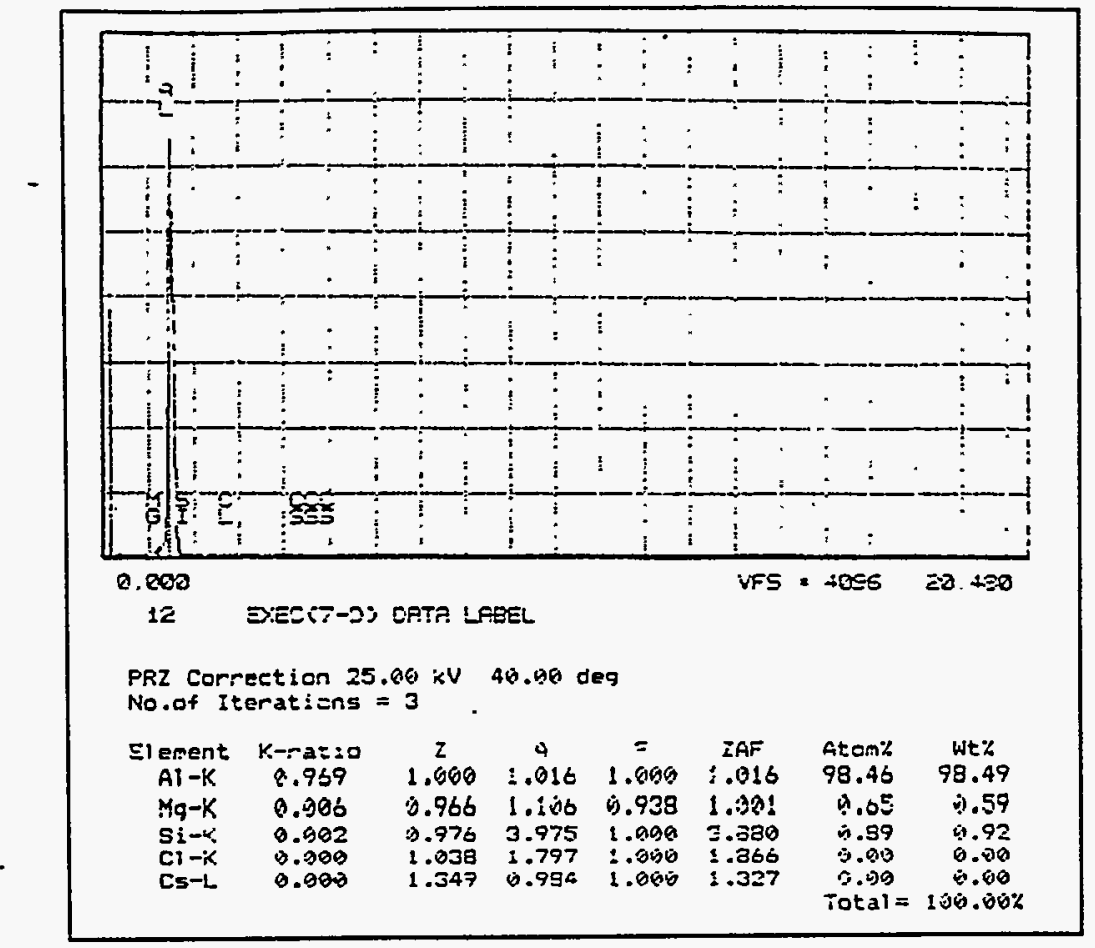

(a)

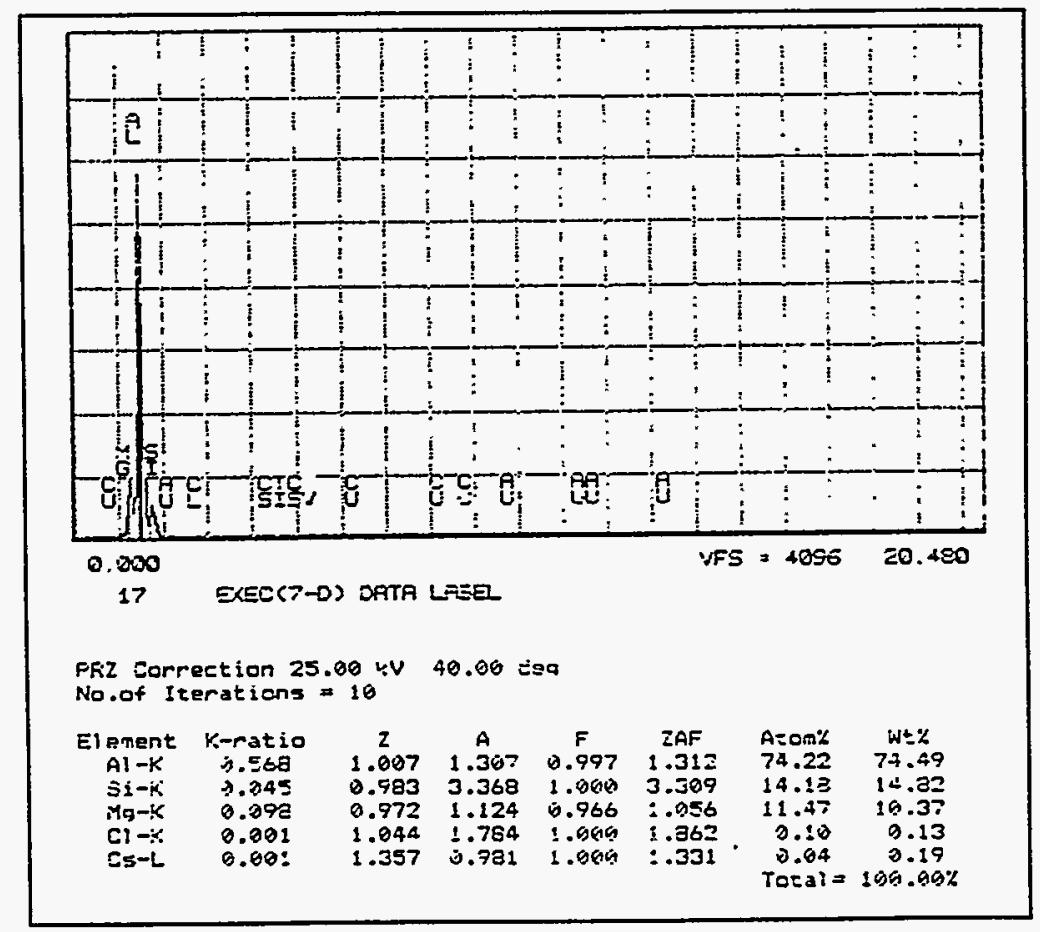

(b)

Figure 17. Local composition and EDX spectrograms of the cross section of the ingot produced in Test 4. (a) $\alpha$-phase; (b) eutetic mixture. 


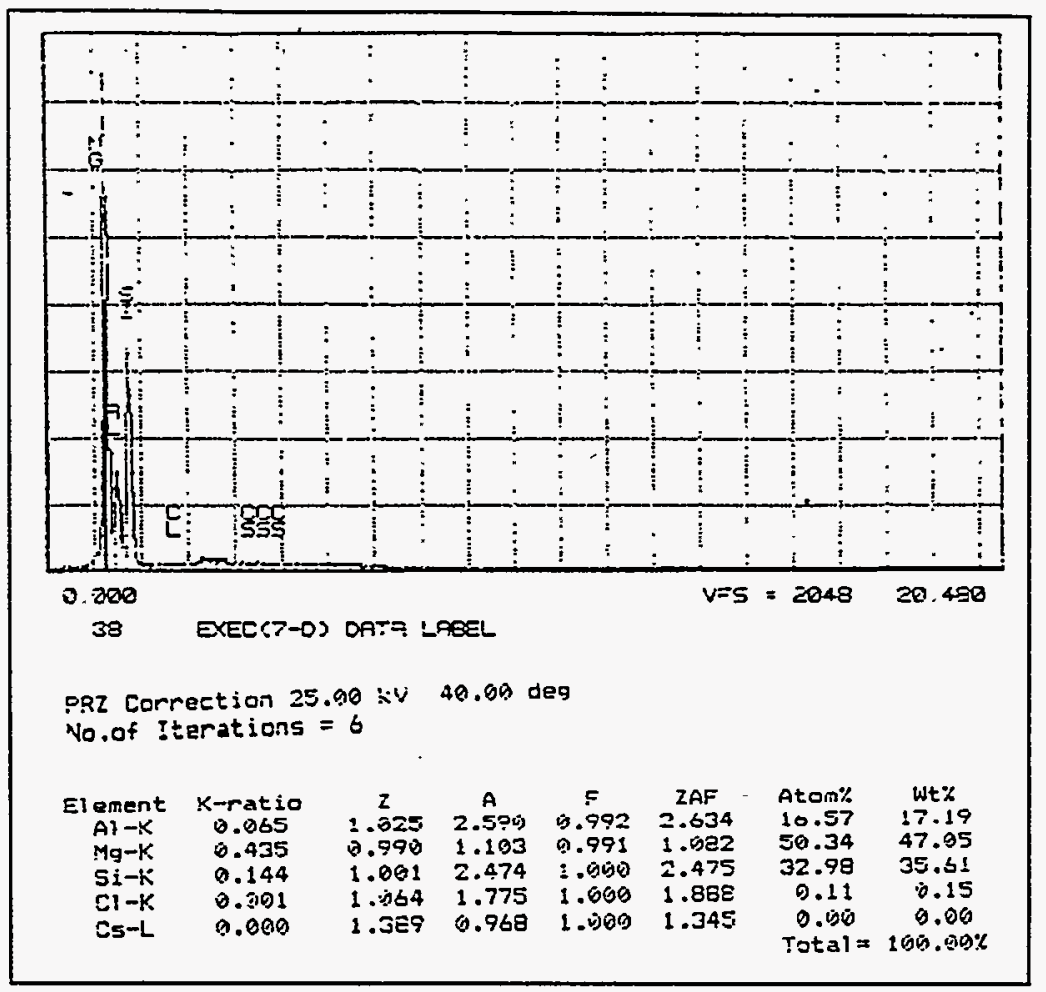

(c)

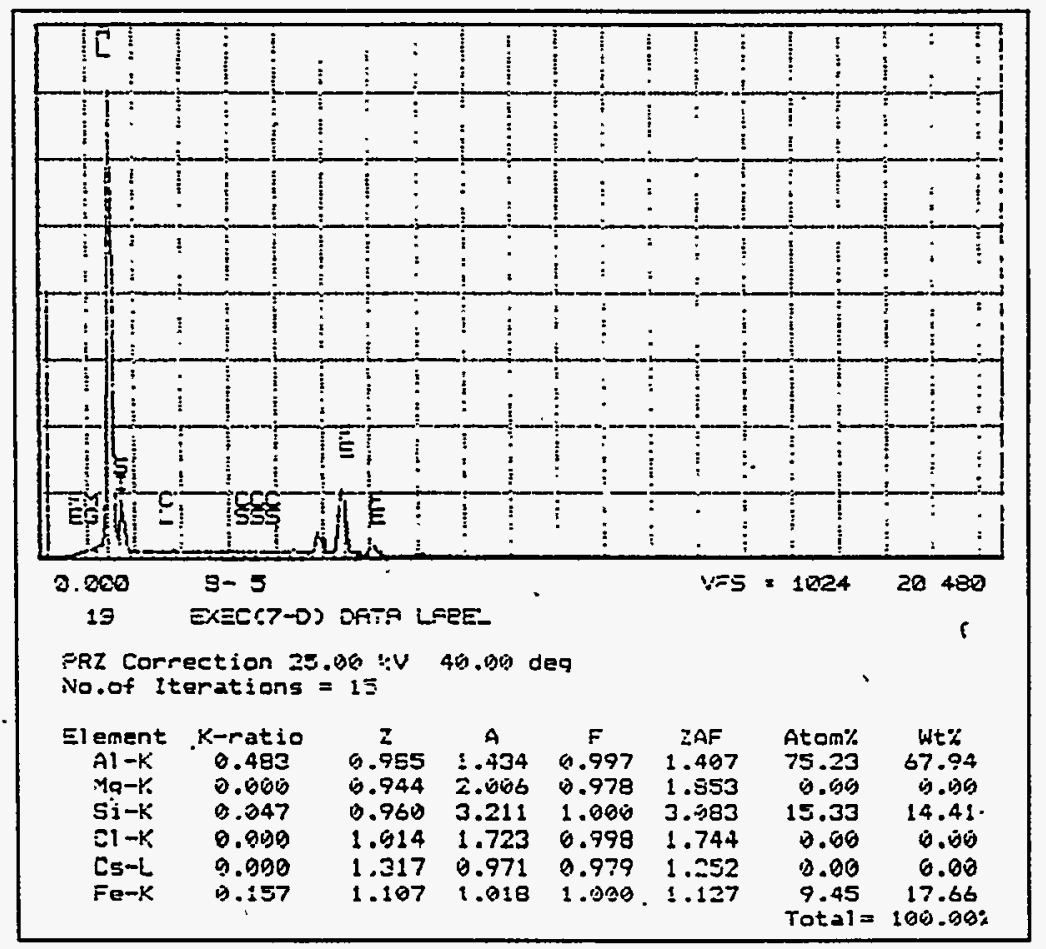

(d)

Figure 17. Local composition and EDX spectrograms of the cross section of the ingot produced in Test 4. (c) Black area in eutetic; (d) bright area in Figure 16. 
With respect to the crucible used in Test 4 , the inner surface and the cap were analyzed using SEM and EDX. On the lower side of the inner wall (surface) of the crucible, a great deal of cesium and some chlorine were found. On the upper side inner surface of the crucible and the bottom surface of the cap, some cesium, chlorine, and magnesium was detected. On the bottom inner surface of the crucible, a layer of black film contained a high percentage of magnesium.

\subsubsection{Test 5}

The melting and solidification of the copper alloy with cesium chloride was also conducted in the helium gas resistance furnace. Two percent cesium chloride was mixed into the copper alloy. The heating rate was $5^{\circ} \mathrm{C} / \mathrm{min}$, while the (maximum) heating temperature was $1150^{\circ} \mathrm{C}$. When this temperature was reached, heating continued for 60 minutes, after which time the material was cooled down to room temperature. The charge (copper alloy and cesium chloride) was then removed from the furnace.

It was observed that the charge had melted completely and solidified into a spheroidal ingot which had subsided at the center of the top surface due to shrinkage. No powder was found. The ingot separated very easily from the crucible, and the crucible remained in good condition after the ingot was removed.

SEM and EDX analyses were conducted on the surfaces and a cross section of the ingot, as shown in Figure 18. The photomicrographs of the top and bottom surfaces are shown in Figures 18 (a)-(c). The photograph of the cross section is displayed in Figure 18d. Cesium chloride was not found on any of the surfaces. However, elements of cesium and chlorine were detected by EDX on the surfaces of the ingot. The composition of these two elements is shown in Table 8.

Table 8.

Composition of the Elements Detected by EDX on the Ingot Surface of Test 5

\begin{tabular}{|c|c|c|}
\hline Location & Cs & Cl \\
\hline Top surface & 0.28 & 0.68 \\
\hline Bottom surface & 0.50 & 0.57 \\
\hline
\end{tabular}




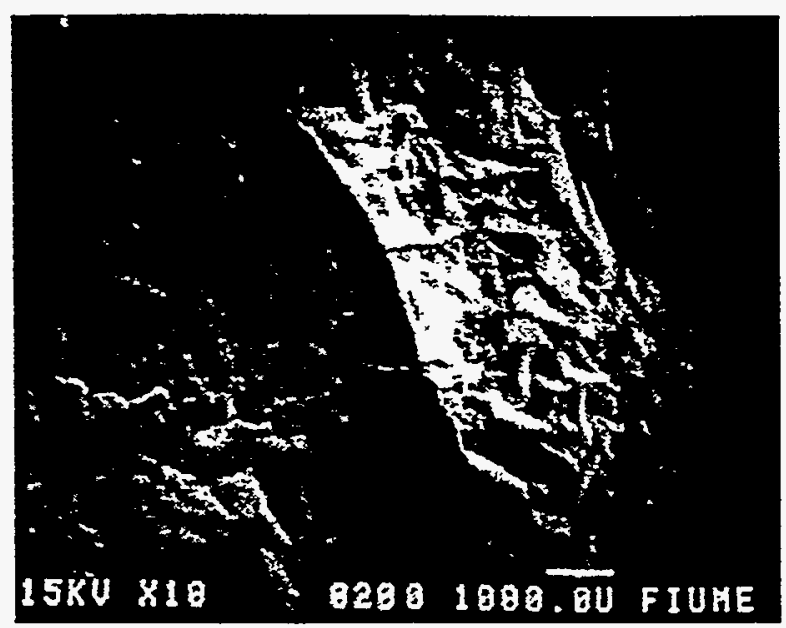

(a)

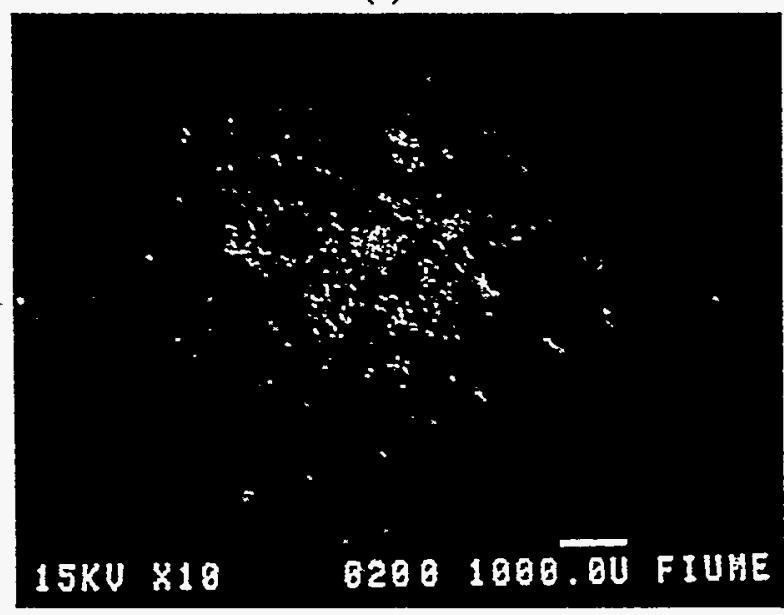

(c)

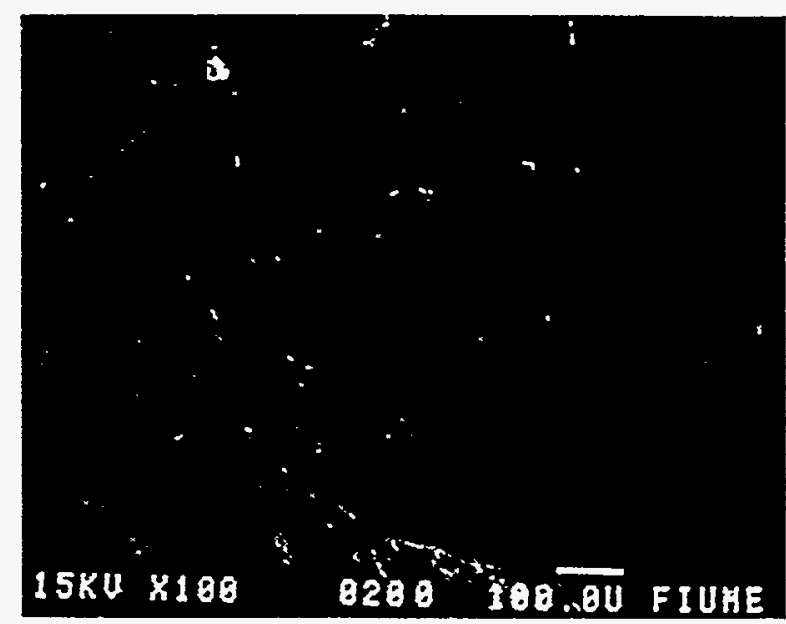

(b)

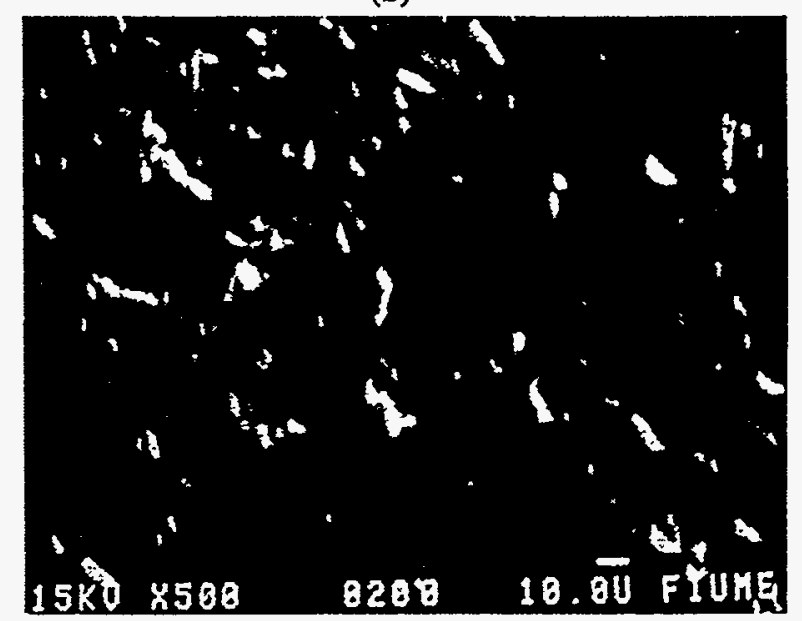

(d)

Figure 18. Microphotographs of the surface of the ingot produced in Test 5. (a) Top, $10 \mathrm{X}$; (b) top, 100X; (c) bottom, 10X; and (d) bottom cross section.

Furthermore, neither cesium nor chlorine was found in the cross section of the ingot. Based on these results, it has been concluded that the cesium chloride did not dissolve in or mix with the copper alloy. This can be attributed to the high temperature heating and the absence of stirring in the melting process. The cesium chloride melted before the copper alloy did. This may indicate that the cesium chloride may partially evaporate when the copper alloy begins to melt. On the other hand, the temperature was still not high enough to melt the copper alloy, and the convection that would cause residual cesium chloride to mix with the copper alloy could not take place. 


\section{NUMERICAL INVESTIGATION}

The numerical investigation of steel and aluminum solidification was conducted to study the solidification rate and temperature distribution.

\subsection{NUMERICAL SIMULATION METHOD}

The numerical simulation of the solidification process was performed using FLUENT.++1 computational fluid dynamics (CFD) software (1996). The enthalpy-porosity technique is used in FLUENT for modeling the phase change process. The solid-liquid interface was determined by computing the liquid fraction in each control volume rather than explicitly tract the interface. The mushy region was modeled as a pseudo-porous medium. Convection inside the liquid metal pool was computed by solving the momentum equations with the Boussinesq assumption.

The energy equation is written in terms of the total enthalpy as follows:

$$
\frac{\partial}{\partial t}(\rho \mathrm{h})+\frac{\partial}{\partial t}(\rho \Delta \mathrm{H})+\frac{\partial}{\partial x_{i}}\left(\rho u_{i} \mathrm{~h}\right)+\frac{\partial}{\partial x_{i}}\left(\rho u_{i} \Delta H\right)=\frac{\partial}{\partial x_{i}}(\mathrm{k} \nabla \mathrm{T})+\mathrm{S}
$$

where the sensible enthalpy, $h$, is defined as

$$
h=h_{\text {ref }}+\int_{T_{\text {ref }}}^{T} c_{p} d T
$$

The term $\Delta \mathrm{H}$ represents the latent heat content, which may vary between 0 (solid phase) and $\mathrm{L}$ (liquid phase). $\mathrm{L}$ is the latent heat of the material. The liquid fraction, $\mathrm{b}$, is introduced as follows:

$$
\beta=\frac{\Delta \mathrm{H}}{\mathrm{L}}=0, \text { if } \mathrm{T}\left\langle\mathrm{T}_{s} \quad \text { and } \quad \beta=\frac{\Delta \dot{\mathrm{H}}}{\mathrm{L}}=1, \text { if } \mathrm{T}\right\rangle \mathrm{T}_{\mathrm{I}}
$$

In the mushy zone, the "level" rule is applied

$$
\beta=\frac{\Delta \mathrm{H}}{\mathrm{L}}=\frac{\mathrm{T}-\mathrm{T}_{s}}{\mathrm{~T}_{1}-\mathrm{T}_{s}} \quad \text { if } \quad \mathrm{T}_{s}\left(\mathrm{~T}<\mathrm{T}_{1}\right.
$$

For a specific alloy, this relationship can be replaced by the actual functional relationship, if known.

The momentum equation was formulated to fit the specific problem. Two source terms were added to the basic Navier-Stokes equations: the bouyancy force using the Boussinesq assumption and the sink term in the mushy zone. In the mushy zone, a large sink was applied to each of the momentum equations to damp the velocity. The sink in the momentum equations takes the form of 


$$
\frac{(1-\beta)^{2}}{\left(\beta^{z}+\varepsilon\right)} \mathrm{A}\left(\mathrm{u}_{\mathrm{i}}-\mathrm{u}_{\mathrm{p}, \mathrm{i}}\right)
$$

where $\mathrm{A}$ is the mushy zone constant ranging from $10^{4}$ to $10^{7}$; $\mathrm{u}_{\mathrm{p} . \mathrm{i}}$ denotes pull velocity if continuous costing is simulated; and $\varepsilon$ is a small number to prevent division by zero.

\subsection{SPECIFICATION OF THE PROBLEM}

The solidification of aluminum and iron in a crucible with $0.1 \mathrm{~m}$ diameter and $0.1 \mathrm{~m}$ height was simulated under different boundary cooling conditions. The cases are described below.

For aluminum, two cases were simulated under the following conditions:

- Initial temperature: $1000 \mathrm{~K}$

- Case 1 boundary condition: The constant temperature of $500 \mathrm{~K}$ is given on the bottom and side boundaries. The top boundary is assumed to be adiabatic.

- Case 2 boundary conditions: Convective boundaries with a heat transfer coefficient of 250 $\mathrm{W} / \mathrm{m}^{2} \mathrm{~K}$ and a cooling temperature of $300 \mathrm{~K}$ on the bottom and side boundaries. The heat transfer coefficient on the top was $50 \mathrm{~W} / \mathrm{m}^{2} \mathrm{~K}$ with $700 \mathrm{~K}$ temperature, considering the covering of slug.

- Case 3 boundary condition: Combined convective and radiation boundaries. The convective conditions were the same as in Case 1. The radiation from the crucible surface was considered. An emissive coefficient of 0.8 was applied, which is an average value of the refractory materials.

For iron, one case was simulated under the following conditions:

- Initial temperature: $1600 \mathrm{~K}$

- Boundary conditions were the same as those in Case 1of the aluminium solidification.

The physical properties of aluminium and iron are listed in Table 9:

Table 9.

Thermal Properties of Aluminium and Iron in Solid and Molten Phase

\begin{tabular}{|l|l|l|}
\hline Property & Aluminium & Iron \\
\hline Melting point $(\mathrm{K})$ & 933.1 & 1548 \\
\hline Latent heat $(\mathrm{KJ} / \mathrm{kg})$ & 394 & 220 \\
\hline Specific heat $(\mathrm{KJ} / \mathrm{kg} \mathrm{K})$ & 1.08 & 0.829 \\
\hline Density in solid $(\mathrm{kg} / \mathrm{m} 3)$ & 2700 & 7200 \\
\hline Thermal conductivity in solid $(\mathrm{W} / \mathrm{m} \mathrm{K})$ & 238 & 80.2 \\
\hline
\end{tabular}


Table 9.

Thermal Properties of Aluminium and Iron in Solid and Molten Phase (Continued)

\begin{tabular}{|l|l|l|}
\hline Density in liquidd $(\mathrm{kg} / \mathrm{m} 3)$ & 2385 & 7000 \\
\hline Thermal conductivity in liquid $(\mathrm{W} / \mathrm{m} \mathrm{K})$ & 94.03 & 44 \\
\hline Viscosity in molten liquid $(\mathrm{kg} / \mathrm{m} \mathrm{s})$ & $1.3 \times 10^{-3}$ & $7.18 \times 10^{-3}$ \\
\hline $\begin{array}{l}\text { Thermal expansion coefficient in liquid } \\
(1 / \mathrm{K})\end{array}$ & $1.174 \times 10^{-4}$ & $6.0 \times 10^{-5}$ \\
\hline Surface tension $(\mathrm{N} / \mathrm{m})$ & 0.914 & 0.845 \\
\hline Surface tension gradient $(\mathrm{N} / \mathrm{m} \mathrm{K})$ & $-3.5 \times 10^{-4}$ & $-3.5 \times 10^{-4}$ \\
\hline
\end{tabular}

\subsection{NUMERICAL SIMULATION RESULTS}

The computing practice indicated that the iteration process for the iron solidification cases was unstable. On the other hand, the computation of the aluminium solidification cases ran very well. The solidification of iron is much slower than that of molten aluminium under the same cooling conditions since iron has much lower thermal conductivity and diffusivity. Natural convection in the liquid metal pool is significant in the early stages of the solidification process. The liquid pool temperature becomes more uniform in the later stages, so the convection inside is very weak. This can be seen from the maximum velocities inside of the molten metal pool as listed in Table 10.

Table 10.

Maximum Velocities in the Molten Metal Pool (m/s)

\begin{tabular}{|l|l|l|l|l|}
\hline $\begin{array}{l}\text { Solidification } \\
\text { Time }\end{array}$ & $\begin{array}{l}\text { Aluminium } \\
\text { Case 1 }\end{array}$ & $\begin{array}{l}\text { Aluminium } \\
\text { Case 2 }\end{array}$ & $\begin{array}{l}\text { Aluminium } \\
\text { Case 3 }\end{array}$ & $\begin{array}{l}\text { Iron } \\
\text { Case 1 }\end{array}$ \\
\hline $10 \mathrm{~s}$ & 0.0144 & & &. \\
\hline $20 \mathrm{~s}$ & 0.003124 & & & \\
\hline $40 \mathrm{~s}$ & & 0.00867 & 0.00858 & 0.0135 \\
\hline $80 \mathrm{~s}$ & & 0.00292 & 0.00267 & 0.00666 \\
\hline $160 \mathrm{~s}$ & & 0.000643 & 0.000279 & 0.00398 \\
\hline
\end{tabular}


The temperature distributions, solidification patterns, and velocity fields for different boundary conditions at different times are shown in Figures 19 through 26 for molten aluminium and in Figures 27 through 29 for molten iron. In the figures, the temperature distribution and solidification pattern are illustrated in one picture. In the half showing the solidification pattern. the blue region represents the solid phase, while the red region represents the liquid phase. The stream function and velocity vectors are combined into one picture.

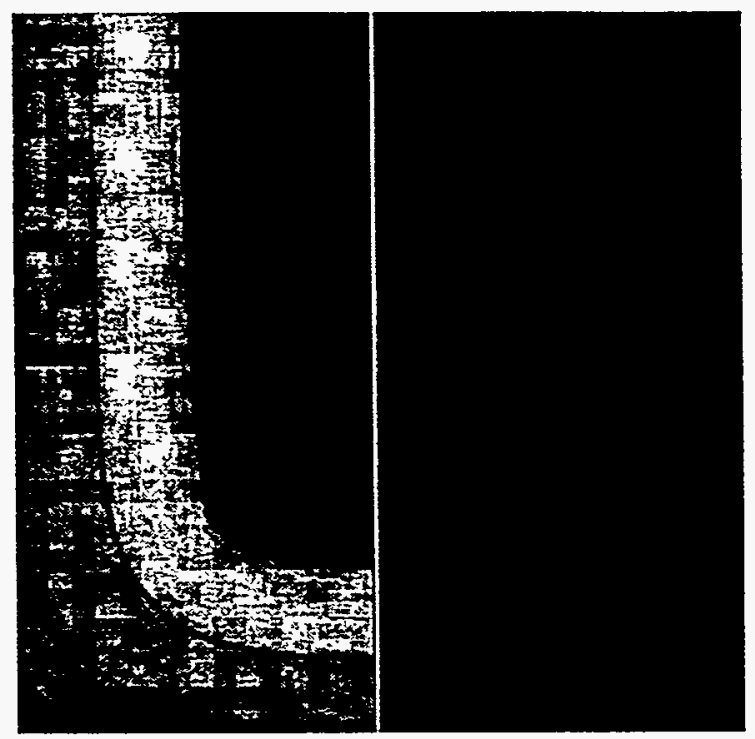

(a)

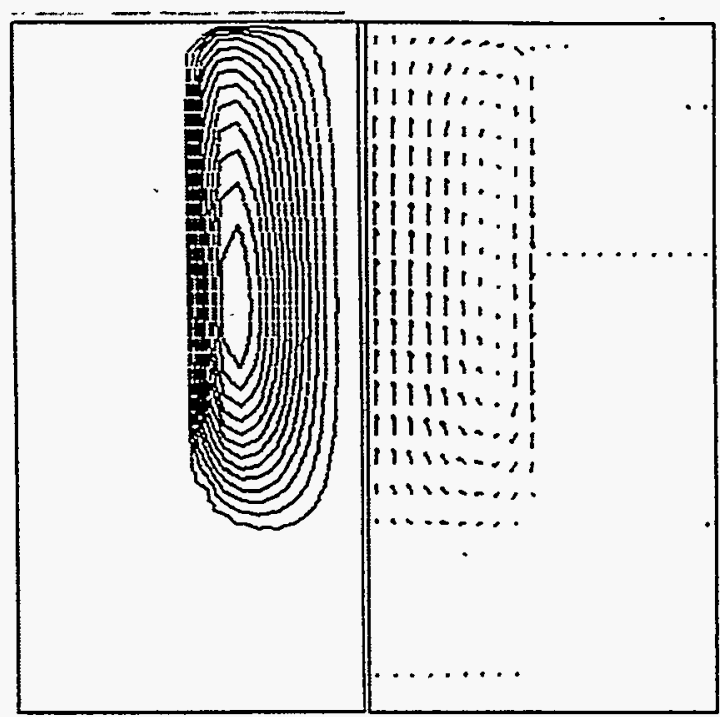

(b)

Figure 19. Temperature distribution, solidification patterns, and flow field for molten aluminum solidification (Case $1, t=10 \mathrm{~s}$ ). (a) Temperature distribution and solidification pattern; (b) Stream function and velocity vectors. 


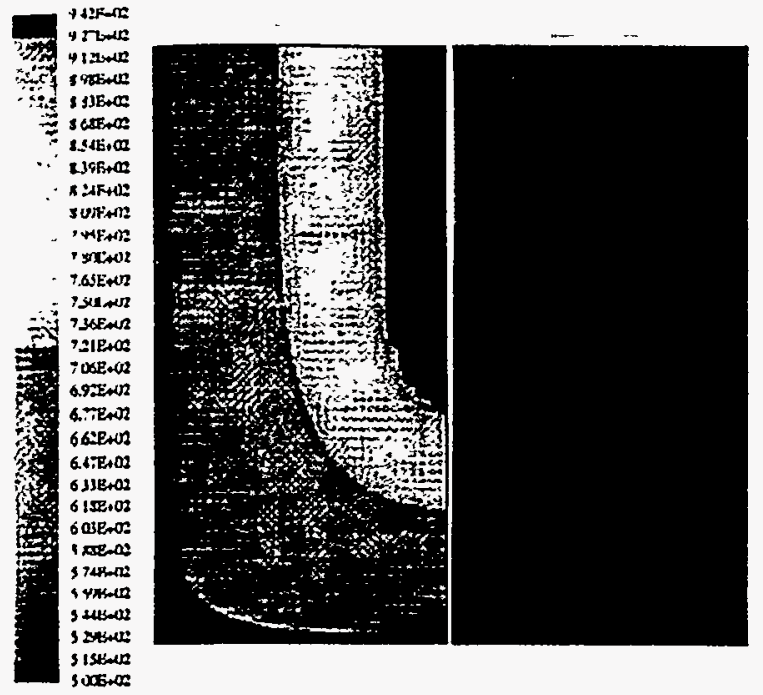

(a)

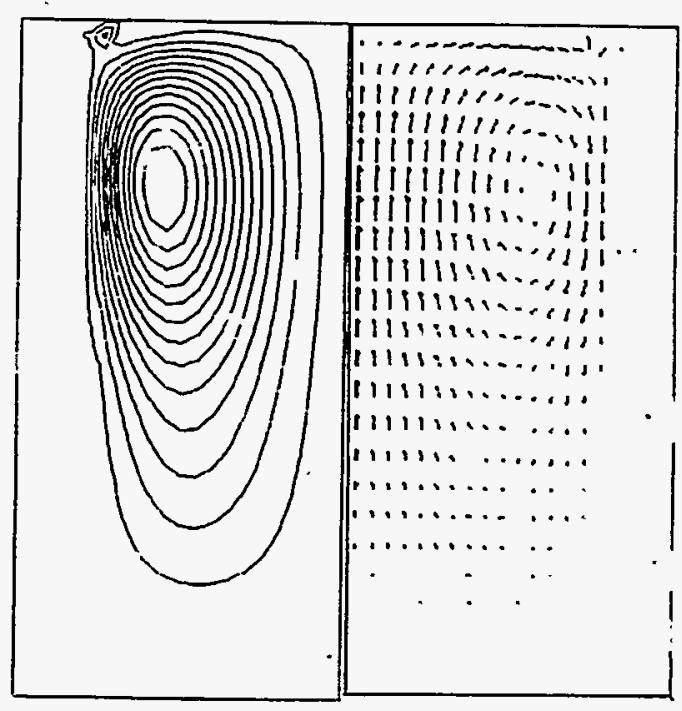

(b)

Figure 20. Temperature distribution, solidification patterns, and flow field of molten aluminum solidification (Case 1, $t=20$ s). (a) Temperature distribution and solidification pattern; (b) Stream function and velocity vectors.
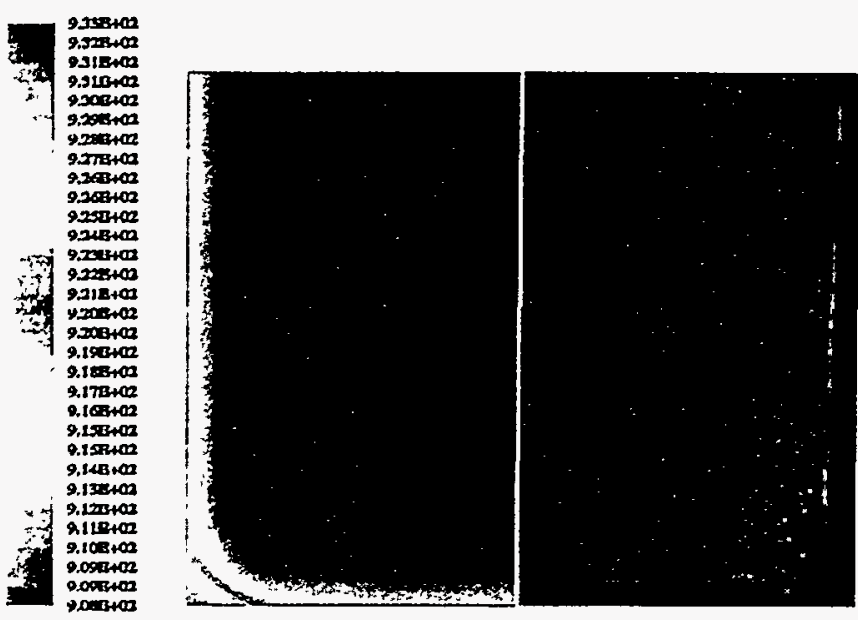

(a)

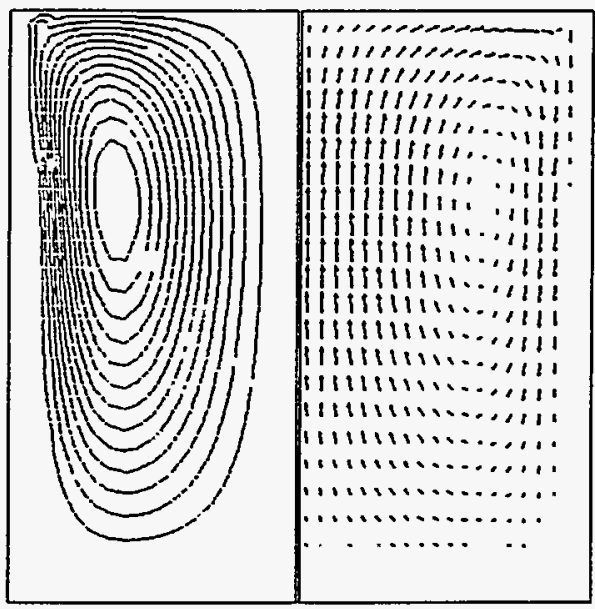

Velocity Vecton (M/S) $\quad$ Max $=8.669 \mathrm{E}-03$

(b)

Figure 21. Temperature distribution, solidification patterns, and flow field for molten aluminum solidification (Case $2, t=40$ s). (a) Temperature distribution and solidification pattern; (b) Stream function and velocity vectors. 


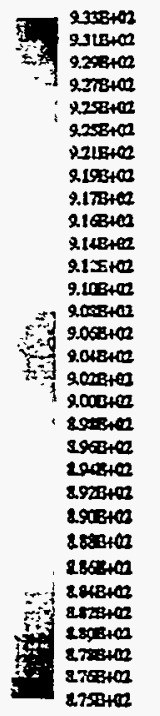

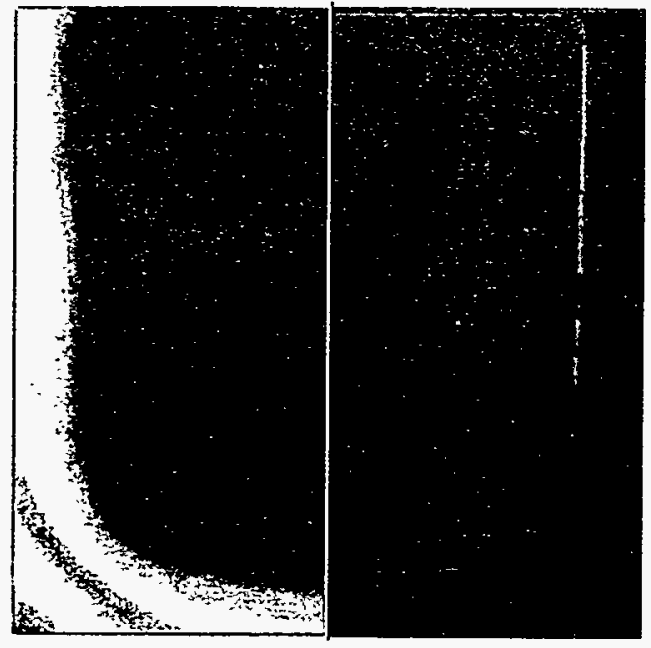

(a)

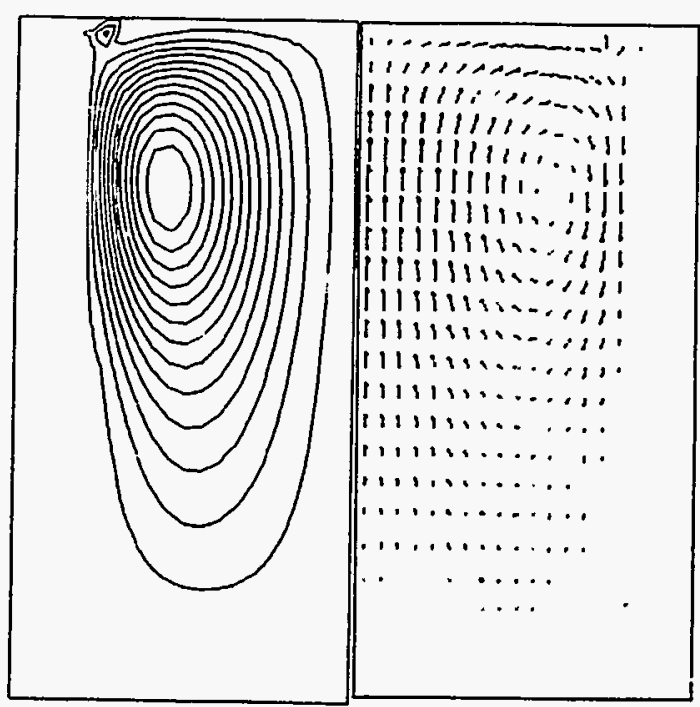

(b)

Figure 22. Temperature distribution, solidification patterns, and flow field for molten aluminum solidification (Case $2, t=80$ s). (a) Temperature distribution and solidification patter; (b) Stream function and velocity vectors.

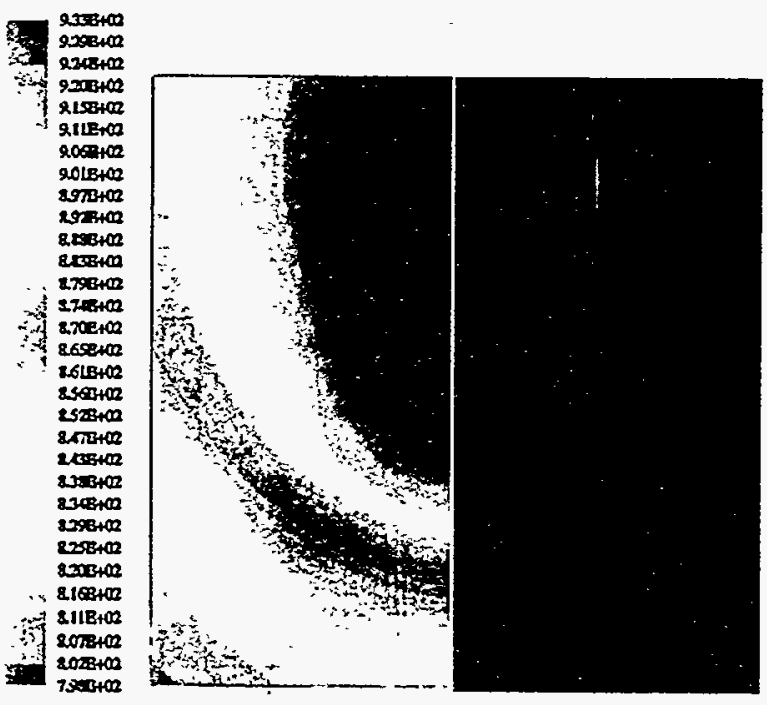

(a)

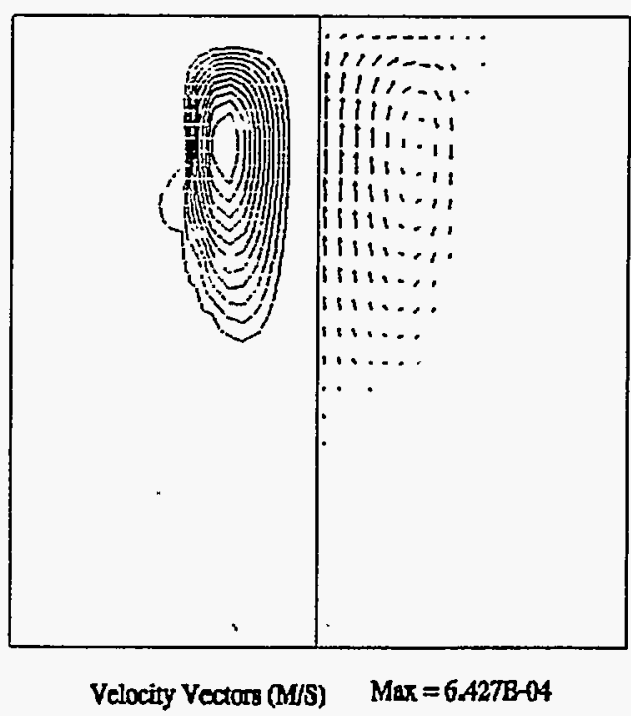

(b)

Figure 23. Temperature distribution, solidification patterns, and flow field for molten aluminum solidification (Case 2, $t=160$ s). (a) Temperature distribution and solidification pattern; (b) Stream function and velocity vectors. 


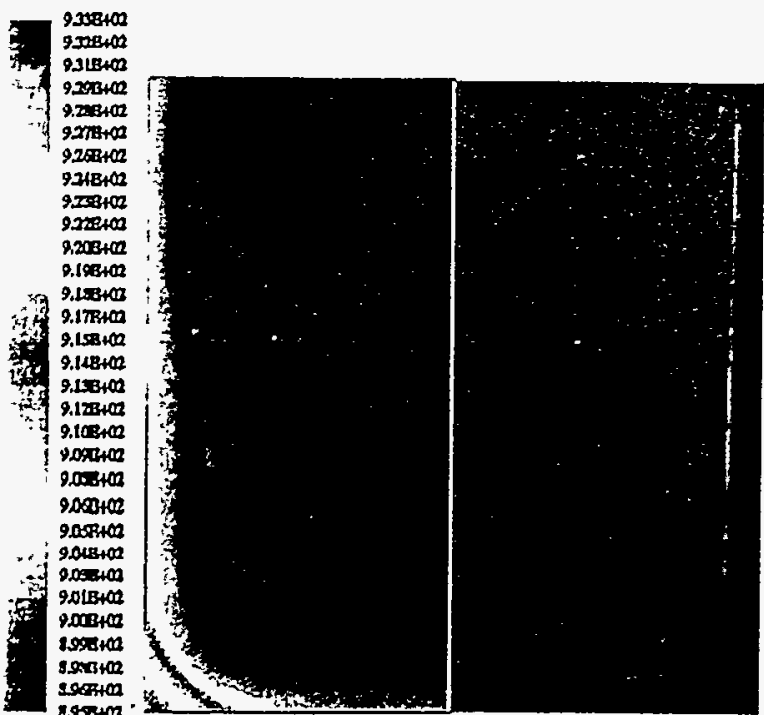

(a)

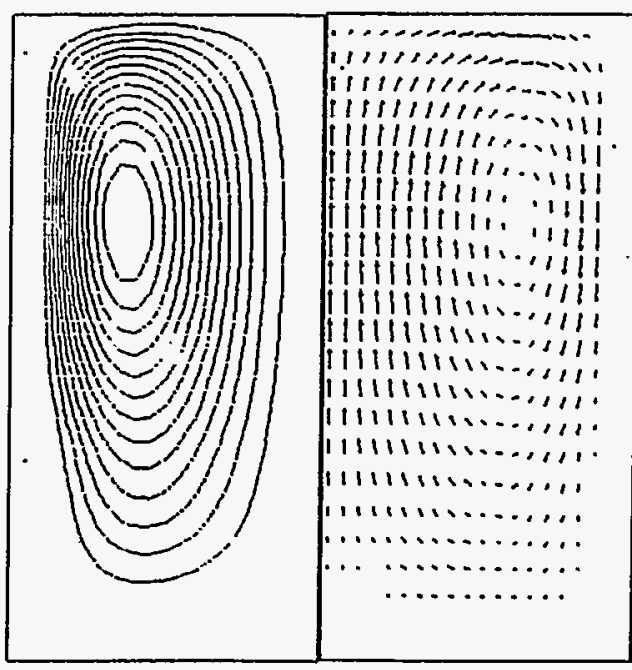

Velocity Vectoses (M/S) Max $=8.578 \mathrm{E}-03$

(b)

Figure 24. Temperature distribution, solidification patterns, and flow field for molten aluminum solidification (Case 3, $t=40 \mathrm{~s}$ ). (a) Temperature distribution and solidification pattern; (b) stream function and velocity vectors.

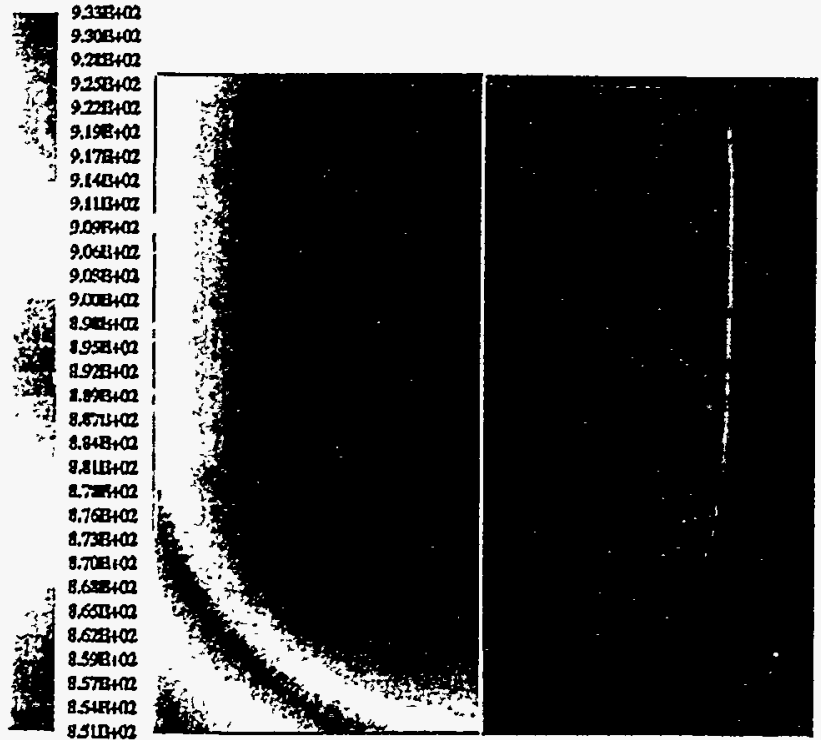

(a)

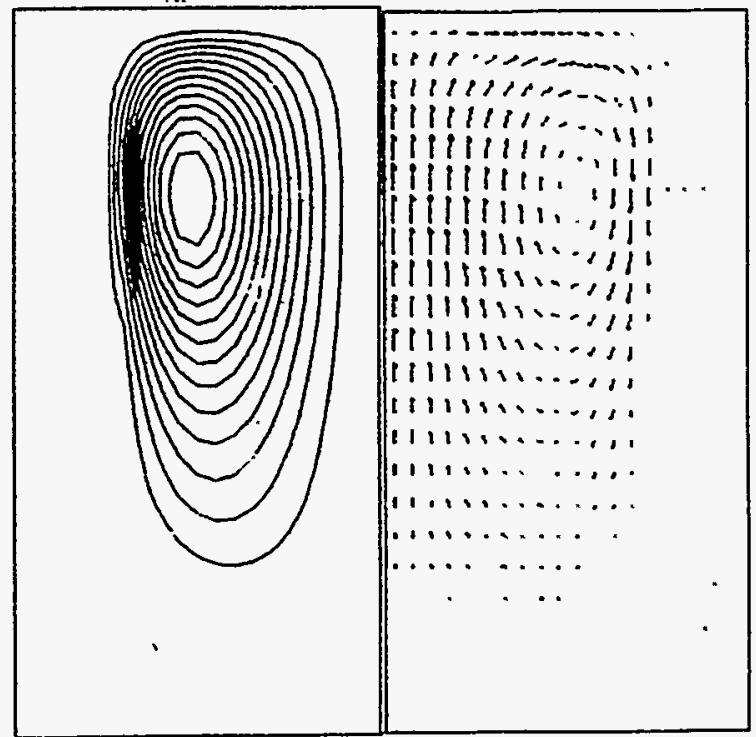

(b)

Figure 25. Temperature distribution, solidification patterns, and flow field for molten aluminum solidification (case $3, t=80 \mathrm{~s}$ ). (a) Temperature distribution and solidification pattern; (b) stream function and velocity vectors. 


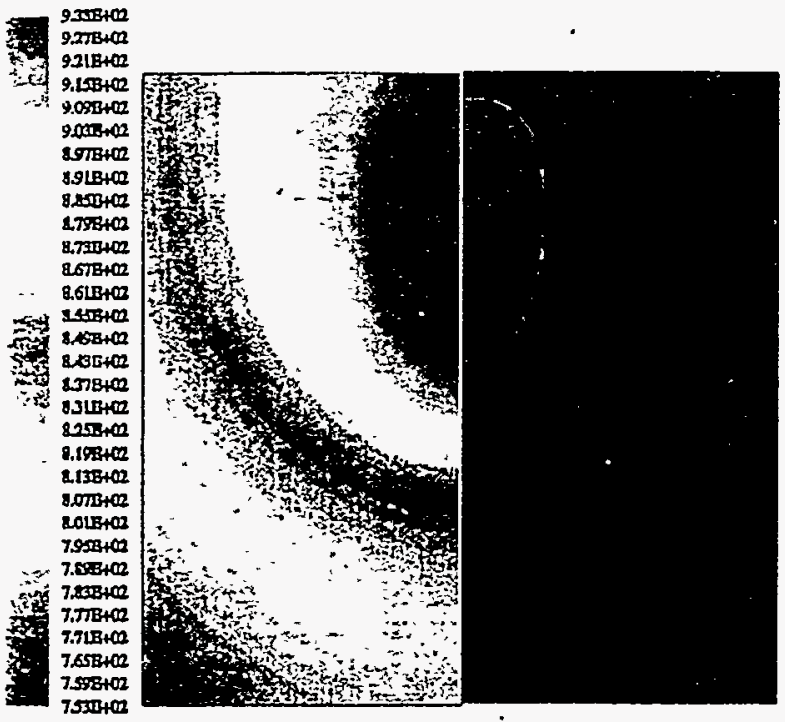

(a)

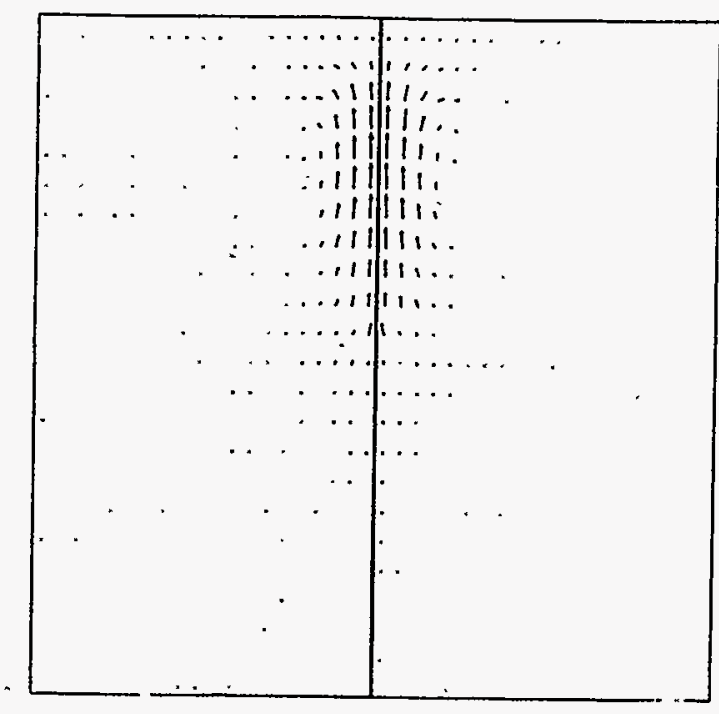

(b)

Figure 26. Temperature distribution, solidification patterns, and flow field for molten aluminum solidification (Case 3, $t=160 \mathrm{~s}$ ). (a) Temperature distribution and solidification pattern; (b) velocity vectors.

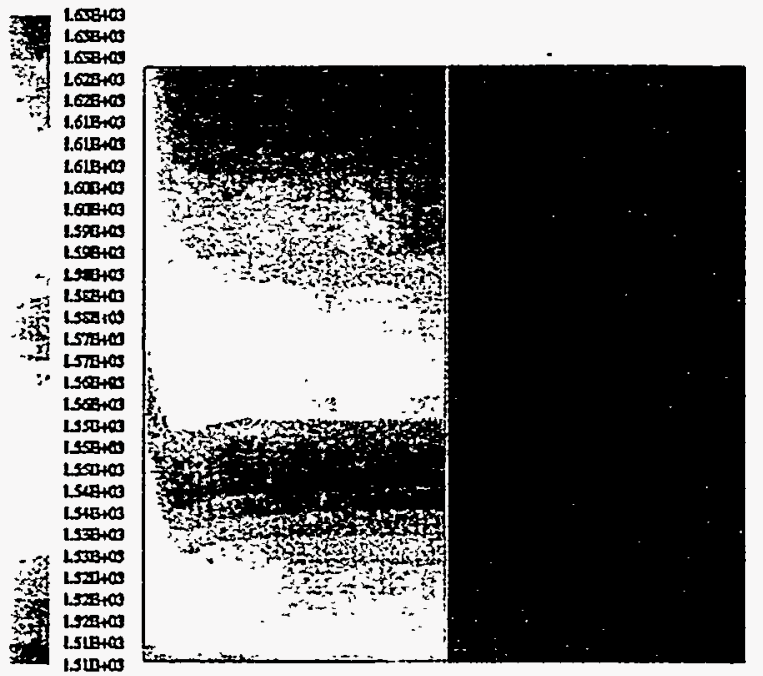

(a)

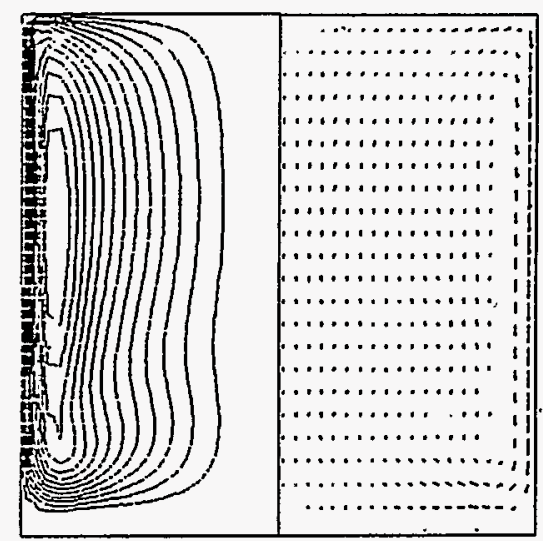

vesotry vectors (MUS) $M a x=1.352 \mathrm{~B}-02$

(b)

Figure 27. Temperature distribution, solidification patterns, and flow field for molten iron solidification (Case 1, t=40 s). (a) Temperature distribution and solidification pattern; (b) stream function and velocity vectors. 


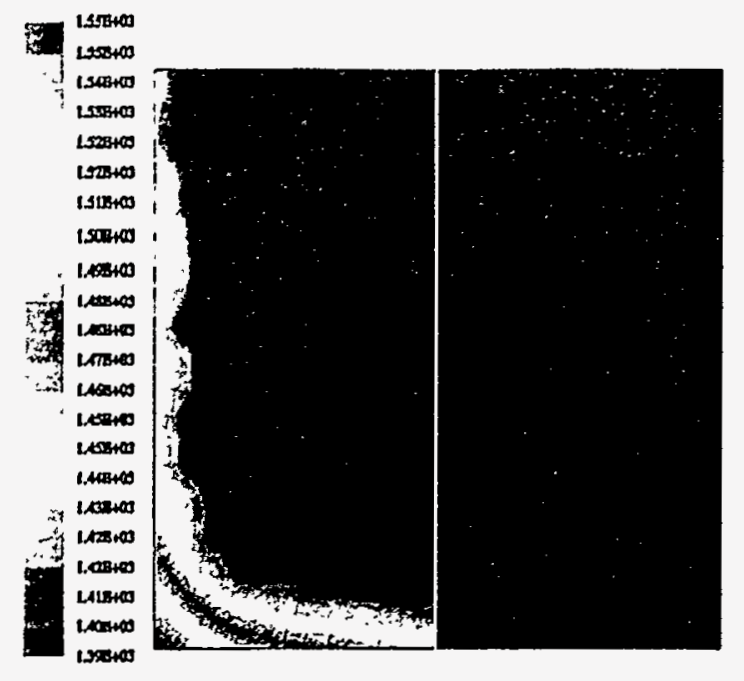

(a)

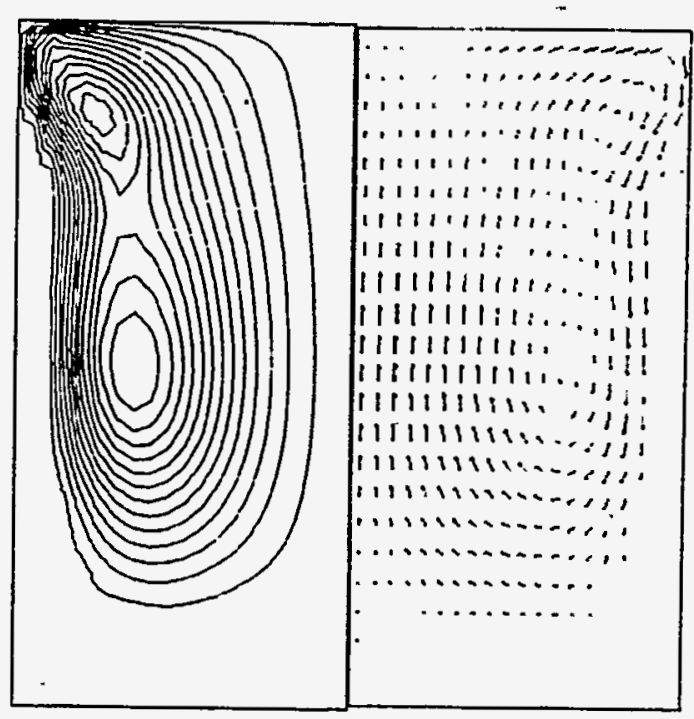

(b)

Figure 28. Temperature distribution, solidification patterns, and flow field for molten iron solidification (Case 1, $t=80 \mathrm{~s}$ ). (a) Temperature distribution and solidification pattern; (b) stream function and velocity vectors.

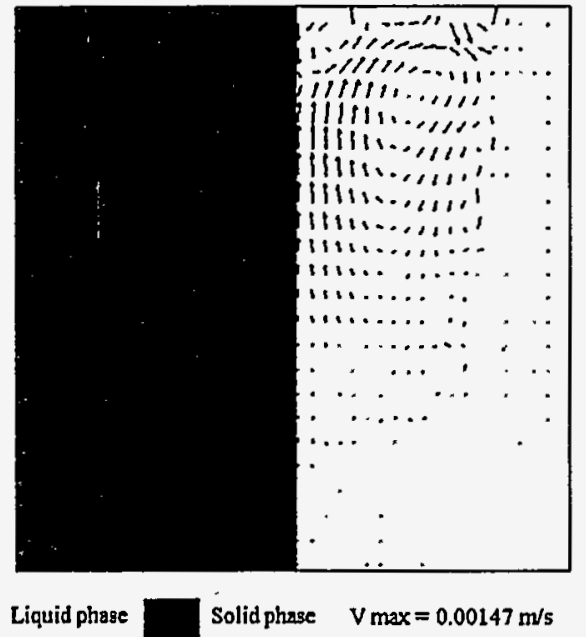

(a)

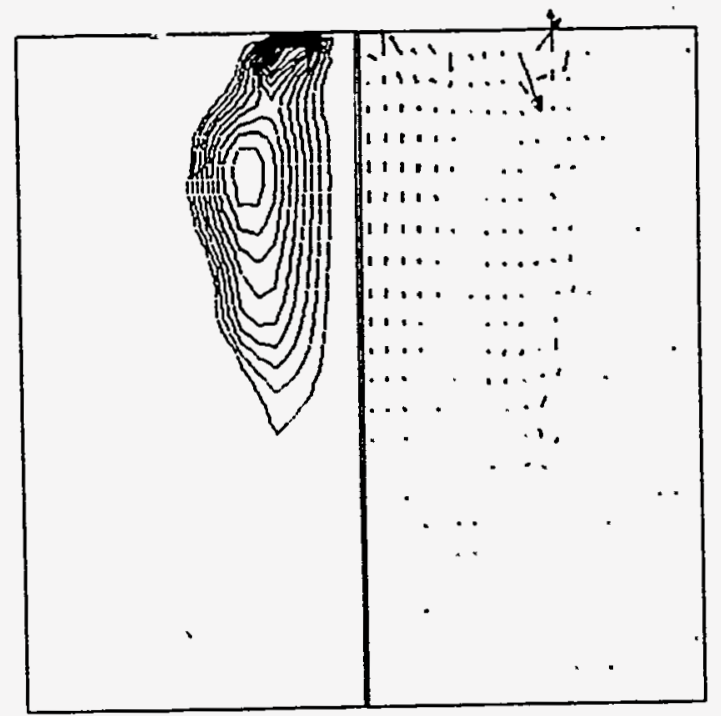

(b)

Figure 29. Temperature distribution, solidification patterns, and flow field for molten iron solidification (Case 1, $t=160 \mathrm{~s}$ ). (a) Temperature distribution and solidification pattern; (b) stream function and velocity vectors. 
It can be seen that the solidification rate for the given temperature boundary condition is much higher than that for convective boundary conditions with or without radiation. The given temperature boundary condition is the solidification limit for the coolant with this same temperature. The effect of radiation from the surfaces to the environment is significant on the solidification rate. This can be seen from the comparison between the results of Cases 2 and 3 of aluminium solidification. The solidification rate of molten iron is much lower than that of molten aluminium. This can be explained by the fact that the iron has much lower heat conductivity and thermal diffusivity than aluminium. 


\section{CONCLUDING REMARKS}

The accomplishments of the project can be summarized as follows:

- The basic characterization process has been established and was implemented successfully.

- The cesium chloride distribution data in the aluminium melting and solidification process was obtained.

- The cesium chloride distribution data in the copper melting and solidification process was obtained.

- The cesium chloride distributed mainly on the bottom and side surfaces of the ingots. Little - cesium chloride was detected on the top surface and the inside of the ingots. It was found that the cesium chloride evaporated during the melting process. The higher the melting temperature, the less cesium chloride residual was left in the ingots.

- The numerical prediction method for the metal solidification process was implemented.

- Solidification rates, flow pattern in molten metal pool, and temperature distribution in the aluminium and steel solidification processes were simulated.

Different heating and cooling rates were tested in the characterization process. The effect of the percentage of radionuclides in the charge was also studied. It was found that the melting temperature and the holding time play important roles in the transfer and distribution of the radionuclide surrogate. The evaporation of the radionuclide surrogate suggests that precautions would be needed to prevent the radionuclides from escaping into the environment in the actual recycling process.

The numerical prediction results indicate that the natural convection flow inside the liquid metal pool is stronger in the beginning of the solidification process; thus, it has a significant effect on the radionuclide distribution in the final ingot: the structure will be more uniform on the top and in the center portions of the ingot than on the bottom and side portions. The reported method and results provide useful information to facilitate the direct simulation of the distribution of radionuclides in the metal ingot. More work remains be done to permit the implementation of the prediction results in the in-situ monitoring and control of the melting and casting process.

The characterization process and test system investigated in this project offers a great deal of flexibility for the study of the melting and solidification of metals. The transfer and distribution of radionuclide surrogates have been characterized for the solidification of aluminium and copper by means of this process.

The implemented characterization process and the obtained results can be used in different areas:

- This characterization process and the obtained results have been developed to supplement the radioactively contaminated scrap metal recycling and refining processes employing the melting slug/refining method; 
- Another potential application is for the refining of the metal phase resulting from the vitrification process, a technique that is highly recommended for the treatment of a variety waste forms, as the metal phase has some cesium chloride and ceric oxide content;

- This characterization process and test system can also be used in general metal recycling and refining; and

- The process and system can also be used in the smelting process to characterize the transfer and distribution of oxide impurities.

The numerical simulation scheme implemented is a general tool for the prediction of thermal and flow transport phenomena in the solidification of various kinds of metals. Solidification patterns, cooling rates, temperature distributions, and velocity fields can be computed by means of the simulation. This information is essential for the monitoring and control of the melting process as well as for the design of the furnace crucible and cooling device.

It is possible to extend this scheme to simulate particle movement and distribution during the metal solidification process. Once successfully developed, this could be used to characterize the transport and distribution of the radionuclides and other ingredients in the molten metals, and would be very helpful in the development of new technologies for radioactively contaminated scrap metals recycling and metal refining.

The present process was only used for a radionuclide surrogate. in addition the results obtained must be tested on a large scale before application in industrial predictions and design. characterization of the melts resulting from both arc and induction melting need to be performed to verify and extend the information for wide use. other radionuclide surrogates or actual radionuclides may be used in future characterization investigations to obtain results that better reflect actual conditions.

The combination of the solidification with the granular multiphase model needs to be explored. The simultaneous modeling of the transport inside and outside of the crucibles is necessary to approach the realistic conditions. More work has to be done to implement the prediction results in the in-situ monitoring and control of the melting and casting process. 
Albers, B.J., and Purdy, C.B., "Spatial Data Technologies for Environmental Applications within the Department of Energy," Earth Observation Magazine, December 1994, pp.18-24.

Anderson, I., Eccleston, G., and Pickrell, M., "Characterization Before Treatment," in Characterizing Containerized Mixed Low-Level Waste for Treatment-a Workshop Proceedings, EPA/600/R-94/149, Ed. G.L. Rupp, Environmental Protection Agency, Cincinnati, 1993.

Bastiaan, G., Iowa State University, Personal Communication (email), February 1996.

Bechtold, T.M.(Editor), INEL Metal Recycle, Annual Report FY-94, Idaho National Engineering Laboratory, Idaho Falls, Idaho, 1994.

Beckermann, C. and Viskanta, R., "Mathematical Modeling of Transport Phenomena During Alloy Solidification," Applied. Mechanics Review, Vol. 46, 1993.

Boettingger, W.L. and Lutz, R.N., The Stainless Steel Beneficial Reuse Integrated Demonstration, Savannah River Site, Aiken, 1994.

Burkhard, W.H., and Eschenbach, R.C., "Recycling of Metals from Waste with Thermal Plasma," Resources, Conservation and Recycling, Vol. 10, 1994, pp. 11-16.

Chen, Y., Im, Y.T., and Lee, J., "Finite Element Simulation of Solidification With Momentum, Heat and Species Transport," Journal of Materials Processing Technology, Vol. 48, 1995, pp. 571-579.

Chen, Y., Im, Y.T., and Yoo, J., "Finite Element Analysis of Solidification of Aluminum with Natural Convection," Journal of Materials Processing Technology, Vol. 52, 1995, pp. 592-609.

Compere, A.L., et al., Contaminated Nickel Scrap Processing, ORNL/TM-12900, Oak Ridge National Laboratory, Oak Ridge, December 1994.

de Groh, Henry C. III, "Undercooling-Induced Macrosegregation in Directional Solidification," Metallurgical and Materials Transactions A: Physical Metallurgy and Materials Science, Vol. 25A, November 1994, pp. 2507-2516.

Duda, J., U.S. Department of Energy's Weapons Complex Scràp Metal Inventory, DOE/METC94/1003, U.S. Department of Energy, Morgantown Energy Technology Center, Morgantown, July 1993.

Edelson, M.C., et al., Characterization, Monitoring, and Sensor Technology Integrated Program (CMST-IP), Proceedings of the International Topic Meeting on Nuclear and Hazardous Waste Management, Spectrum' 94, American Nuclear Society, La Grange Park, IL, 1994, p. 299.

Fluent Inc., FLUENT User's Guide, Volume 2, Release 4.4, Lebanon, NH, August 1996. 
Frazee B., Idaho National Engineering Laboratory (INEL), Personal Communication, September $15,1993$.

Hassel, G.R., Geimer, R.M., Batdorf, J.A., and Leatherman, G.L., Evaluation of the Plasma Hearth Procéss for Mixed Waste Treatment Applications, DOE-RAPIC 08679, presented at the 1994 Incineration Conference, Houston, 1994.

Hobbick C.W., Schatz, D.R., and Aden, G.D., Distribution and Removal of Radionuclides in Molten Stainless Steel, RHO-CD-1444 (DOE-RAPIC 00477), Rockwell International, Richland, 1981.

Krautkramer, J, Krautkramer, H., Ultrasonic Testing of Materials, Springer-Verlag, New York, 1977.

Kuznetsov, A.V. and Vafai, K., "Development and Investigation of Three-Phase Model of the Mushy Zone for Analysis of Porosity Formation in Solidifying Castings," International Journal of Heat and Mass Transfer, Vol. 38, 1995, pp. 2557-2567.

Larsen, M.M., et al., Sizing and Melting Development Activities Using Contaminated Metal at the Waste Experimental Reduction Facility, EGG-2411, Idaho National Engineering Laboratory (INEL), Idaho Falls, February 1985. .

Lockheed Idaho Technologies Company, Decontamination of Metals by Melt Refining/Slagging, Lockheed Idaho Technologies Company, INEL-95/0123, January 1995.

Mautz, E.W., et al., Uranium Decontamination of Common Metals by Smelting: A Review (Handbook), NSA 3204, National Lead Company of Ohio, Cincinnati, February 1975.

May, J.L and Wahnschaffe, S.D., Engineering Study for a Melting, Casting, Rolling, and Fabrication Facility for Recycled Contaminated Stainless Steel, INEL-94/0242, Alpha Engineering Inc., Centerline Engineering Corp. Lockheed Idaho Technologies Company, January 1994.

Moldovan, P., et al., "Complex Processing of Molten Secondary Aluminum," Journal De Physique IV, Vol. 3, November 1993, pp. 847-855.

MSE Inc. and Manufacturing Science Corporation (MSC), Feasibility Analysis of Recycling Radioactive Scrap Steel, DOE/LD-12735-T38, September 1995.

Muth, T.R., Moore, J., Olson, D., and Mishra, B., Advanced Technologies for Decontamination and Conversion of Scrap Metals, presented at Opportunity '95-Environmental Technology Through Small Business, Morgantown, November 1994.

Nakamura, H., Kanazawa, K., Sato, T. Yamate, K., and Fujiki, K, Fundamental Research on Melting of Radioactive Metal Materials, Proceedings of the International Topical Meeting on Nuclear and Hazardous Waste Management Spectrum'94, American Nuclear Society, La Grange, IL, 1994, pp. 206-210. 
Ni, J., Incropera, F.P., "Extension of the Continuum Model for Transport Phenomena Occurring during Metal Alloy Solidification-I. The Conservation Equations," International Journal of Heat and Lfass Transfer, Vol. 38, 1995a, pp. 1271-1284.

$\mathrm{Ni}$, J., Incroperā, F.P., "Extension of the continuum model for transport phenomena occurring during metal alloy solidification-II. Microscopic considerations," International Journal of Heat and Mass Transfer, Vol. 38, 1995b, pp. 1285-1296.

Nieves, L.A., Chen, S.Y., Kohout, E.J., Nabelssi, B., Tilbrook, R.W., and Wilson, S.E., Evaluation of Radioactive Scrap Metal Recycling, ANL/EAD/TM-50, Environmental Assessment Division, Argonne National Laboratory (ANL), Argonne, December 1995.

Nishioka, M., Hirai, S., Yanagisawa, K., "Solidification of Glass Powder with Simulated HighLevel Radioactive Waste During Hydrothermal Hot-Pressing," Journal of the American Ceramic Society, Vol. 73, 1990, pp. 317-322.

Oak Ridge National Laboratory (ORNL), High-Temperature Chemical Separations of Waste Materials, http://www.ornl.gov/, February 1994.

Ochiai, A., Kitagawa, K., and Sawada, Y., "Treatment of Plutonium-Contaminated Metallic Waste by the Electro-slag Melting Method," Conditioning of Radioactive Wastes for Storage and Disposal, Proceedings of an International Symposium, Utrecht, Netherlands, June 21-25, 1982.

Office of Environmental Management Technology Development, Characterization, Monitoring, and Sensor Technology Crosscutting Program-Technology Summary, DOE/EM-0254, Office of Environmental Management Technology Development, Washington D.C., June 1995.

Office of Technology Development and Office of Environmental Restoration and Waste Management, Technical Program Plan for the Transitioning, Decommissioning, and Final Disposition Focus Area, DOE/NBM-1101, Office of Technology Development, Office of Environmental Restoration and Waste Management, Washington D.C., January 1994.

Ostrogorsky, A.G. and Dragojlovic, Z., "Heat and Mass Transfer in Solidification by the Submerged Heater Method," Transport Phenomena in Solidification, American Society of Mechanical Engineers, Heat Transfer Division, HTD Vol. 284, New York, 1994, pp. 255-263.

Paradies, C.J., Smith, R.N., and Glicksman, M.E., "Effects of Mixed Convection on Dendrite Fragmentation During Alloy Solidification," Transport Phenomena in Solidification," American Society of Mechanical Engineers, Heat Transfer Division, HTD Vol. 284, ASME, New York, 1994, pp. 161-169.

Patsiogiannis, F., et al., "Laboratory-Scale Refining Studies on Low Carbon Aluminum Killed Steels Using Synthetic Fluxes," ISIJ International, Vol. 34, No. 2, 1994, pp. 140-149,. 
Pincock L, and Wahnachaffe S., System Approach to the Management of a Contaminated Metal Recycle Project, High Level Radioactive Waste Management-Proceedings of the Annual International Conference, Vol. 2. ASĆE, New York, 1994, pp. 1069-1073.

Prescott, P.J., Incropera, F.P., and Gaskell, D.R., "Convective Transport Phenomena and Macrosegregation During Solidification of a Binary Metal Alloy; Experiments and Comparisons with Numerical Predictions," Journal of Heat Transfer, Vol. 116, 1994, pp. 742-749.

Prescott, P.J. and Incropera, F.P., "Convective Transport Phenomena and Macrosegregation During Solidification of a Binary Metal Alloy; Numerical Predictions," Journal of Heat Transfer, Vol. 116, 1994b, pp. 735-741.

Prescott, P.J. and Incropera, F.P., "Effect of Turbulence on Solidification of a Binary Metal Alloy with Electromagnetic Stirring," Journal of Heat Transfer, Vol. 117, 1995, pp. 716724.

Prescott, Patrick J., Incropera, and Frank P., "Magnetically damped convection during solidification of a binary metal alloy. Numerical simulations.," Transport Phenomena in Materials Processing and Manufacturing, HTD Vol.196, American Society of Mechanical Engineers, Heat Transfer Division, New York, 1992, pp. 51-58.

Purdy, C.B. et al., Development of Site Characterization Technologies within the Characterization, Monitoring, and Sensor Technology Integrated Program (CMST-IP), NP, 1994, p. 433.

Reimann, G.A., Technical Assessment of Processes to Enable Recycling of Low-Level Contaminated Metal Waste, EGG-MS-9879, Idaho National Engineering Laboratory (INEL), Idaho Falls, October 1991.

Shahani, H., Amberg, G., and Fredriksson, H., "On the Formation of Macrosegregation in Unidirectionally Solidified $\mathrm{Sn}-\mathrm{Pb}$ and $\mathrm{Pb}-\mathrm{Sn}$ Alloys," Metallurgical and Materials Transactions A, Vol. 23A, 1992, pp. 2301-2311.

Sinha, S. K., Sundararajan, T., and Garg, V.K., "Anisotropic Porous Medium Model for Alloy Solidification," Transport Phenomena in Materials Processing and Manufacturing, American Society of Mechanical Engineers, Heat Transfer Division, HTD Vol.196, New York, 1992, pp. 193-200.

Sundarraj, S., Voller, V.R., "Development of a Microsegregation Model for Application in a Micro-Macro Model," Micro/Macro Scale Phenomena in Solidification," American Society of Mechanical Engineers, Heat Transfer Division, HTD Vol. 218, New York, 1992, pp. 35-42.

Uda, T. et al., "Melting of Uranium-Contaminated Metal Cylinders by Electroslag Refining," Nuclear Technology, Vol. 79, 1987, pp. 328-337.

Wang, C.Y., Beckermann, C., "A Multiphase Solute Diffusion Model for Dendritic Alloy Solidification," Metallurgical Transaction A, Vol. 24 A, December 1993, pp. 2787-2802 
Wang, C.Y., Beckermann, C., "Multi-Scale/Phase Modeling of Dendritic Alloy Solidification," Transport Phenomena in Solidification, American Society of Mechanical Engineers, Heat Transfer Division, HTD Vol. 284, New York, 1994, pp. 75-95.

Wang, P.W., ef al., Characterization, Monitoring, and Sensor Technology Integrated Program (C.MST-IP): An Overview of Emerging Technologies in Site/Waste Characterization and Waste Treatment Monitoring, Proceedings of the Symposium of Waste Management' 94, Tucson, 1994, p. 1085.

Warren, S. and Clark, D.E., Technical Issues Relating to the Recycle of Contaminated Scrap Metal, U.S. Department of Energy, Office of Environmental Restoration (EM-43), Westinghouse Hanford Co., Richland, 1994.

Worcester, S.A., Twidwell, L.G., Paolini, D.J., Weldon, T.A., and Mizia, R.E., Decontamination of Metals by Melt Refining/Slagging: First Year Progress Report, WINCO-1198, DOE, Idaho National Engineering Laboratory (INEL), Westinghouse Idaho Nuclear Company, Inc., March 1994.

Worcester, S.A., Twidwell, L.G., Paolini, D.J., Weldon, T.A., and Mizia, R.E., Decontamination of Metals by Melt Refining/Slagging-An Annotated Bibliography: Update on Stainless Steel and Steel, WINCO-1138, Westinghouse Idaho Nuclear Company, Inc., Idaho Falls, July 1993. 